Universidade de São Paulo

Faculdade de Medicina de Ribeirão Preto

Harnoldo Colares Coelho

\title{
PREVALÊNCIA E FATORES DE RISCO PARA A INFECÇÃO DO HIV NA POPULAÇÃO CARCERÁRIA MASCULINA DA PENITENCIÁRIA DE RIBEIRÃO PRETO
}

Ribeirão Preto 2004 


\section{Harnoldo Colares Coelho}

\section{PREVALÊNCIA E FATORES DE RISCO PARA A INFECÇÃO DO HIV NA POPULAÇÃO CARCERÁRIA MASCULINA DA PENITENCIÁRIA DE RIBEIRÃO PRETO}

Dissertação apresentada à Faculdade de Medicina de Ribeirão Preto da Universidade de São Paulo para obtenção do Título de Mestre.

Área de Concentração: Saúde na Comunidade, Departamento de Medicina Social.

Orientador: Prof. Dr. Afonso D.C. Passos

Ribeirão Preto

2004 
Coelho, Harnoldo Colares.

Prevalência e fatores de risco para a infecção do HIV na população carcerária masculina da Penitenciária de Ribeirão

Preto. Ribeirão Preto, 2004.

115 p.: il. ; $30 \mathrm{~cm}$

Dissertação de Mestrado apresentada à Faculdade de Medicina de Ribeirão Preto - Universidade de São Paulo Área de concentração: Saúde na Comunidade.

Orientador: Prof. Dr. Passos, Afonso Dinis Costa.

1.HIV. 2.Prisões. 3.Prevalência. 4.Fatores de risco. 
Aos meus pais, Gerardo e Gema, fontes de toda perseverança, sabedoria e honestidade, dedico com muito amor este trabalho. 
Às minhas filhas, Clara e Cecília, pelo estímulo constante à felicidade.

À minha maravilhosa esposa, Raquel, pelo companheirismo, compreensão, paciência e o mais completo amor. 


\section{AGRADECIMENTOS}

Ao Prof. Dr. Afonso Dinis Costa Passos por toda dedicação, orientação e amizade.

Ao Programa de DSTIAIDS da Secretaria de Saúde de Ribeirão Preto pelo financiamento do material de coleta e teste sorológico, especialmente a enfermeira Fátima Regina de Almeida Neves.

À direção da Penitenciária de Ribeirão Preto por dar permissão a realização deste trabalho, principalmente o Dr. Maurici Antonio Turnes, chefe da divisão médica.

Á auxiliar de enfermagem Maria do Carmo Prado Logarezi e à enfermeira Maria do Carmo Coutinho de Oliveira por participarem ativamente na coleta de sangue dos presidiários.

Aos funcionários do laboratório de sorologias do Castelo Branco: Eduardo, Gislaine, Lídia, Renata, Elaine, Raquel e do Instituto Adolfo Lutz: Lilia.

Aos Professores Jorge Achcar e Gleici Perdona pelo auxílio na análise estatística dos dados.

Aos docentes do Serviço de Moléstias Infecciosas do HCFMRP. Profs. Drs.: Roberto Martinez, José Fernando, Luiz Tadeu, Alcione Artioli, Benedito Fonseca e João Carlos Costa por me estimular a buscar mais conhecimentos.

Aos funcionários do Departamento de Medicina Social da FMRP: Rosane, Carolina, Regina, Mônica, Solange, Sidney e Gilmar por serem sempre prestativos e atenciosos. 
Aos amigos Profs. Marta Edna e Juan Stuardo Rocha pelo permanente suporte a mim e a minha família desde a nossa chegada em Ribeirão Preto.

Ao colega e amigo Valdes Roberto Bollela pelo incentivo e apoio incondicional.

Aos amigos e primos Keny Colares e Danielle Malta companheiros eternos.

Aos amigos ex-integrantes da colônia cearense ribeirão pretana: Roberto, Elodie, Beatriz, Renan, Ana Paula, Mariana, Max, Paula, João Fernando e Cíntia. Para vocês minha eterna gratidão por momentos felizes e a certeza de muita saudade.

A todos agentes penitenciários da Penitenciária de Ribeirão Preto pela colaboração à realização deste trabalho.

A todos os presidiários participantes que tornaram este trabalho em realidade. 


\section{RESUMO}

COELHO, H.C. Prevalência e fatores de risco para a infecção do HIV na população carcerária masculina da Penitenciária de Ribeirão Preto. 2004. 115 p. Dissertação Mestrado. Faculdade de Medicina de Ribeirão Preto, Universidade de São Paulo, Ribeirão Preto.

A infecção pelo HIV em presidiários alcança uma das maiores prevalências entre subgrupos populacionais específicos, com taxas de até $17 \%$ já tendo sido descritas no Brasil e no mundo. Contribuem para isso diversos comportamentos de risco, adotados já antes do encarceramento ou desenvolvidos durante o período de reclusão. Entre eles, destacam-se o uso de drogas ilícitas intravenosas, compartilhamento de agulhas e seringas e atividade sexual desprotegida. Esta pesquisa objetivou estimar a prevalência do marcador do HIV e fatores de risco para esta infecção na população masculina carcerária da Penitenciária de Ribeirão Preto - SP, no período de maio a agosto de 2003. Do total de 1030 presidiários, foram sorteados 333 participantes por amostragem casual simples, os quais foram submetidos à aplicação de um questionário padronizado e tiveram coletada uma amostra de sangue. Para diagnóstico sorológico do HIV foi utilizado inicialmente o ensaio imunoenzimático (ELISA), como teste de triagem, com a confirmação sendo feita através de reação de imunofluorescência indireta (IFI). A prevalência global encontrada para o HIV nos presidiários foi de 5,7\% (IC 95\%:3,2 - 8,2). Todas as variáveis que mostraram associação com a presença do anti-HIV, através de análise univariada, foram submetidas a um modelo multivariado de regressão logística utilizando o método Baysiano. Nesta análise, as variáveis que se mostraram preditoras de forma independente da infecção pelo HIV foram: Incircuncisão, homossexualismo masculino, tempo total da pena a ser cumprida inferior a cinco anos, uso de droga injetável e compartilhamento de agulhas e seringas.

Palavras-chave: 1. HIV; 2. Prisões; 3. Prevalência; 4. Fatores de risco. 


\section{ABSTRACT}

COELHO, H.C. Prevalence and risk factors for HIV infection in male prisoners in Ribeirão Preto. 2004. 115 p. Dissertação Mestrado. Faculdade de Medicina de Ribeirão Preto, Universidade de São Paulo, Ribeirão Preto.

The human immunodeficiency virus (HIV) infection in prisoners reaches one of the highest prevalence among specific population subgroups, with rates up to $17 \%$ already described in Brazil and in some parts of the world. Several risk behaviours, adopted before or during the imprisonment, accounts for that. Among them, the use of intravenous illicit drugs, sharing of needles and syringes and unprotect sexual activity are the most important. This survey aimed to estimate the prevalence of HIV serological marker and risk factors for this infection in men inmates at the Penitentiary of Ribeirão Preto, State of São Paulo, Brazil, between May and August 2003. Out of 1030 inmates, a simple random sample of 333 participants was chosen. Demographic information, as well as risk factors for HIV infection, were obtained through the application of a standardized questionnaire. A blood sample of $10 \mathrm{ml}$ was taken from each participant. An enzyme-linked immunosorbent assay (ELISA) was used as a screening test for HIV, with the diagnosis being confirmed by indirect immunofluorescence. The overall prevalence for HIV in inmates was 5,7\% (CI 95\%: 3,2 - 8,2). All the variables identified as associated with HIV infection, through univariate analysis, were assessed by a logistic regression multivariate model, using the Baysian method. At the level of 5\%, HIV infection was associated with history of sharing of needles/syringes and total time of punishment less than five years. Associations at the level of $10 \%$ were observed with the variables lack of circumcision, homosexuality and history of intravenous illicit drugs.

Key words: 1. HIV. 2. Prisons. 3. Prevalence. 4. Risk fators. 


\section{LISTA DE TABELAS}

Tabela 1- Distribuição dos presidiários nos pavilhões estudados e seus respectivos participantes.

Tabela 2- $\quad$ Valores da média, desvio padrão, mediana e amplitude de variação nos presidiários.

Tabela 3- Distribuição dos presidiários segundo idade e pavilhão...

Tabela 4- Distribuição dos presidiários segundo local de nascimento e pavilhão

Tabela 5- Distribuição dos presidiários segundo local de residência e pavilhão.

Tabela 6- Distribuição dos presidiários segundo estado civil e pavilhão

Tabela 7- Distribuição dos presidiários segundo exame anti-hiv prévio e pavilhão.

Tabela 8- Distribuição dos presidiários segundo tipo de droga não injetável usada no passado e pavilhão.

Tabela 9- Distribuição dos presidiários segundo idade e uso de drogas ilícitas não injetáveis.

Tabela 10- Distribuição dos presidiários segundo idade e uso de drogas ilícitas injetáveis.

Tabela 11- Distribuição dos presidiários segundo idade e sorologia HIV

Tabela 12- Distribuição dos presidiários segundo pavilhão e sorologia HIV.

Tabela 13- Distribuição dos presidiários segundo escolaridade e sorologia HIV.

Tabela 14- Distribuição dos presidiários segundo tempo da pena total e sorologia HIV.

Tabela 15- Distribuição dos presidiários segundo ter realizado exame anti-HIV prévio e sorologia HIV

Tabela 16- Distribuição dos presidiários segundo DST prévia não ulcerativa e sorologia HIV 
Tabela 17- Distribuição dos presidiários segundo número de parceiras um ano antes da prisão e sorologia HIV

Tabela 18- Distribuição dos presidiários segundo preferência sexual e sorologia HIV.

Tabela 19- Distribuição dos presidiários segundo número de parceiras um ano antes da prisão e sorologia HIV.

Tabela 20- Distribuição dos presidiários segundo circuncisão e sorologia HIV

Tabela 21- Distribuição dos presidiários segundo já ter tido relações sexuais com usuária de drogas ilícitas e sorologia HIV.....

Tabela 22- Distribuição dos presidiários segundo uso de drogas ilícitas injetáveis no passado e sorologia HIV.

Tabela 23- Distribuição dos presidiários segundo compartilhamento de agulha no passado e sorologia HIV

Tabela 24- Distribuição dos presidiários segundo transfusão sanguínea no passado e sorologia HIV.......................... 48

Tabela 25- Distribuição dos presidiários segundo passado de hepatite e sorologia HIV

Tabela 26- Distribuição dos presidiários segundo antecedente de icterícia e sorologia HIV.

Tabela 27- Média a posteriori e intervalos de credibilidade para os coenficientes do modelo de regressão logística 


\section{SUMÁRIO}

1- INTRODUÇÃ

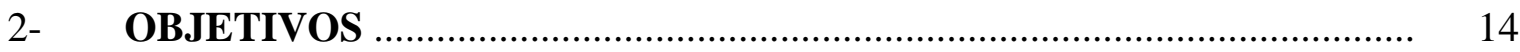

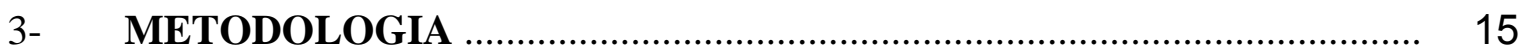

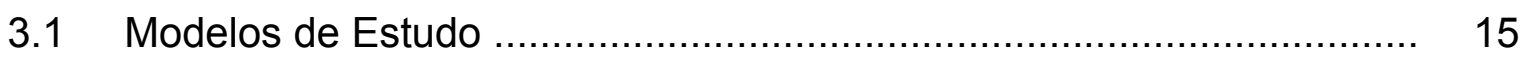

3.2 Divisão da População Carcerária................................................. 15

3.3 População de Referência...................................................... 16

3.4 População de Estudo e Tamanho Amostral................................... 16

3.5 Critérios de Inclusão.............................................................. 17

3.6 Critérios de Exclusão.................................................................. 17

3.7 Localização da Penitenciária e Local de Estudo............................... 17

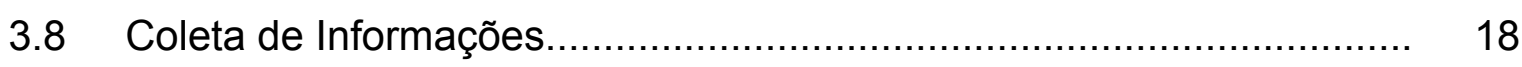

3.9 Variáveis Estudadas Através do Questionário................................. 18

3.10 Coleta de Sangue................................................................. 24

3.11 Análise Sorológica..................................................................... 25

3.12 Descrição dos Métodos Sorológicos................................................. 26

3.13 Digitação e Organização dos Dados.............................................. 28

3.14 Análise Estatística............................................................... 28

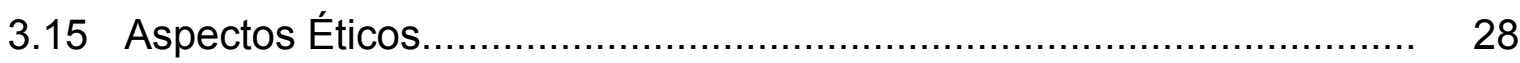

4- RESULTADOS 29

4.1 Aspectos Descritivos da População de Estudo.................................... 29

4.2 Resultados do Estudo de Associação entre Positividade Sorológica ao HIV e Possíveis Fatores de Risco................................................. 38

4.3 Análise Multivariada........................................................ 49

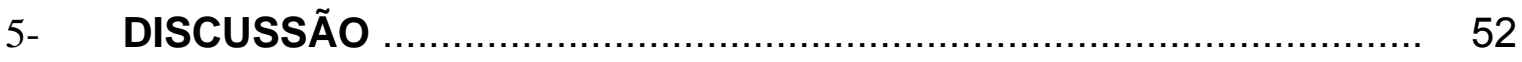

5.1 Considerações Gerais ........................................................... 52

5.1.1 Divulgação da Pesquisa entre os Presidiários ................................. 53

5.1 .2 Inclusão dos Participantes........................................................... 54 
5.1.3 Acesso e Contato com os Presidiários ……..................................... $\quad 55$

5.1.4 Considerações sobre Aplicação do Questionário ............................... 57

5.1.5 Coleta do Exame de Sangue ……………............................... 57

5.2 Discussão dos Resultados .............................................................. 58

5.2.1 Aspectos descritivos da população estudada .................................. 58

5.2.2 Resultados do estudo de associação de marcadores do HIV com Fatores de risco

64

5.3 Considerações Finais .................................................................... 73

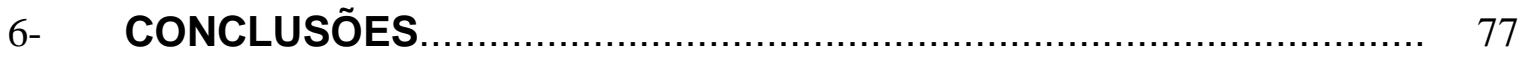

REFERÊNCIAS BIBLIOGRÁFICAS............................................... 78

APÊNDICE 1 - Termo de consentimento......................................... 109

APÊNDICE 2 - Questionário.......................................................... 111 


\section{INTRODUÇÃo}

As Doenças Sexualmente Transmissíveis (DSTs) são uma das principais causas de infertilidade, incapacidade temporária e morte, levando a diversos transtornos de ordem física e psicológica para milhões de pessoas. As DSTs são um grupo de doenças de transmissão, predominantemente por contato sexual, e têm uma das maiores taxas entre as moléstias infecciosas notificáveis em diversos países.

Há mais de 20 patógenos transmitidos por via sexual. Dentre estes, existem os agentes bacterianos considerados clássicos, causadores da sífilis, gonorréia e cancro mole, que vem sendo substituídos, nos últimos anos, por agentes virais, tanto em importância quanto em freqüência. Estes novos transmissores, considerados como a segunda geração das DSTs, são freqüentemente mais difíceis de tratar e controlar, podendo causar sérias complicações. A lista de complicações e seqüelas tardias associadas às DSTs aumentou consideravelmente. Isto decorreu porque muitas complicações previamente não suspeitadas e seqüelas tardias tornaram-se evidentes $^{29}$.

De acordo com a Organização Mundial da Saúde (OMS), estimaram-se 340 milhões de novos casos de sífilis, gonorréia, tricomoníase e infecção por clamídia em adultos de idade de 15 a 49 anos no ano de 1999 em todo mundo1.

Este número mostra um grande aumento nos casos, comparado ao ano de 1990, onde foram registrados 250 milhões de casos destas mesmas DSTs acima descritas na mesma faixa etária ${ }^{30}$. Neste período de quase dez anos, a taxa de crescimento global das DSTs foi de $36 \%$. No Brasil ocorrem, segundo a OMS, mais 12 milhões de casos de DSTs por ano'.

As DSTs são hiperendêmicas em muitos países, inclusive nas áreas rurais, e geralmente têm menores possibilidades de terem um diagnóstico e tratamento apropriados. A exata magnitude das DSTs entre as populações é freqüentemente desconhecida, e isso se deve ao grande número de infecções que são assintomáticas. Além disso, somente uma parte dos indivíduos sintomáticos procura o sistema de saúde para atendimento e, destes, apenas um pequeno número de 
casos são notificados. Outro fator de relevância para a subestimação dos casos de DSTs é o estigma social que é associado à condição de portador. Essa situação faz com que o paciente procure formas alternativas de tratamento ou, até mesmo, em boa parte dos casos, a não procurar tratamento algum.

No momento em que as doenças transmissíveis, incluindo-se as DSTs, já não faziam mais parte do rol das principais enfermidades nos países industrializados, eis que surge uma nova enfermidade infecciosa que se alastraria rapidamente por todo o mundo: a Síndrome da Imunodeficiência Adquirida (AIDS).

Reconhecida inicialmente nos Estados Unidos (EUA), em 1981, esta síndrome foi descrita em homossexuais do sexo masculino, que apresentavam pneumonia por Pneumocystis carinii e neoplasia do tipo sarcoma de Kaposi, características de quadro de imunodeficiência ${ }^{31-35}$. O agente etiológico que causa esta imunodeficiência foi isolado pelo grupo de Luc Montagnier e denominado "Lymphadenopathy Associated Virus" (LVA) ${ }^{36}$, que posteriormente passaria a ser conhecido como Vírus da Imunodeficiência Humana (HIV). Acredita-se que este vírus tenha origem a partir de um outro vírus de material genético similar encontrado em chimpanzés que habitam a região central da África ${ }^{43,44}$. Apesar de existir o conhecimento de que a AIDS surgiu no continente africano, a localização geográfica específica da origem e difusão permanece incompleta. Evidências apontam para a África Central como área inicial endêmica do HIV e de propagação para Europa Ocidental, Caribe e Américas, da metade para o final da década de $1970^{45}$.

A AIDS é uma doença transmissível, existindo três formas principais de contágio: contato sexual ${ }^{37}$, com transmissão tanto nas relações sexuais entre homossexuais masculinos ${ }^{38}$, quanto nas relações heterossexuais ${ }^{39}$; contato com sangue contaminado, principalmente, transfusões sanguíneas e compartilhamento de seringas entre usuários de drogas injetáveis (UDI $)^{40,41}$; e transmissão vertical mãe para filho ${ }^{42}$, também conhecida como perinatal.

De acordo com a Joint United Nations Programme on HIVIAIDS (UNAIDS), os casos de AIDS registrados durante o ano de 2003 foram de 5 milhões de novos infectados e uma estimativa de 40 milhões de adultos e crianças convivendo com a soropositividade $^{2}$. No global, desde o início da epidemia, quase 70 milhões de indivíduos já se infectaram com o $\mathrm{HIV}^{46}$ e mais de 25 milhões foram a óbito ${ }^{52}$. A cada dia, 14.000 novas infecções ocorrem no mundo, metade destas em indivíduos de 15 a $24 \operatorname{anos}^{51}$, e as projeções são de 100 milhões de infectados ao final da década em 
curso, com um número assustador de 45 milhões de óbitos ${ }^{52}$. Destes 100 milhões, metade estaria concentrada em cinco países: Nigéria, Etiópia, Rússia, Índia e China $^{53}$. Atualmente, existem 14 milhões de órfãos causados pela AIDS $^{54}$. A pior situação da epidemia se encontra na região da África sub-Saariana, onde a devastação de seu impacto tem aumentado consideravelmente nos últimos anos. A prevalência do HIV nesta região está entre 7,5 a $8,5 \%^{2}$ na população adulta (15-49 anos); e a região inclui sete países, todos no cone sudeste, onde há mais de um em cinco adultos portador do vírus. Destes sete países, a situação é mais desesperadora em Botsuana, onde a prevalência entre os adultos é de $36 \%{ }^{47,48}$. Em algumas partes desta região da África, mulheres jovens mostram, até seis vezes maior probabilidade de estarem contaminadas com o HIV do que jovens do sexo masculino ${ }^{51}$.

Segundo a Organização Pan Americana de Saúde (OPAS), nas Américas foram notificados até junho do ano passado, 1.202.147 pacientes com AIDS e um total acumulado de 653.825 mortes $^{49}$. Nesta região, os EUA são o país com o maior número de casos; com o total acumulado até dezembro de 2001 de 816.149 indivíduos e 467.910 óbitos $^{50}$. Os primeiros casos relatados fora dos EUA foram no Haiti, em $1983^{77}$.

Na América Latina e Caribe, os casos de AIDS aumentaram, no período de 1986-87, mais de $95 \%$ naquela e $113 \%$ nesta região, enquanto na América do Norte a elevação foi de $40 \%^{81}$. De acordo com a UNAIDS/OMS/OPAS, a estimativa de infecção pelo HIV, em adultos, nas Américas, na virada do século seria de 1 em 200 pessoas, com uma taxa de prevalência por volta de $0,56 \%$, sendo $1,96 \%$ somente no Caribe $^{85}$. A epidemia difere enormemente entre e dentro dos países, principalmente no que se refere às formas de transmissão ${ }^{55}$. No México, América do Sul e países andinos o que predomina é a forma de contacto homo/bissexual e UDI. Já na América Central e Brasil a forma de transmissão heterossexual vem ganhando espaço. Nos países do Caribe, a principal forma é também a heterossexual ${ }^{78} . \mathrm{Na}$ Argentina, os UDI correspondem a $41,9 \%$ dos casos de AIDS relatados, no Uruguai $26,3 \%$ e Paraguai $11 \%{ }^{79}$. Os homossexuais foram os indivíduos mais afetados pela AIDS na América Latina e Caribe, e continuam a ser o grupo mais vulnerável a infecção e morte pelo HIV ${ }^{80}$. 
Para tentar deter o avanço da infecção na América Latina e Caribe, os respectivos governos uniram-se em parceria com a sociedade civil organizada, através de organizações não-governamentais (ONGs) e Universidades ${ }^{82-84}$.

No Brasil, o primeiro paciente com AIDS conhecido é de 1980, no Estado de São Paulo, e o seu diagnóstico foi estabelecido retrospectivamente em $1985^{56}$. O primeiro caso autóctone do Brasil foi um paciente homossexual masculino de 41 anos com quadro disseminado de Mycobacterium avium-intracellulare, diagnosticado no final do ano de $1982^{57}$. O último boletim epidemiológico da Coordenação Nacional de DST/AIDS, de dezembro de 2002, mostra que os casos de AIDS acumulam, de 1980 até dezembro do ano passado, 257.780 infecções em adultos e crianças ${ }^{25}$. Durante o ano de 2002, foram notificados mais 9.495 novos casos, sendo 6.031 verificados no sexo masculino e 3.464 no feminino ${ }^{25}$. Ainda no nosso país, há uma estimativa média de 597.443 pessoas de 15 a 49 anos portadoras assintomáticas e sintomáticas pelo HIV, em dezembro de $2000^{26}$.

Tal como nos EUA, o início da epidemia de AIDS em nosso país deu importância à forma de transmissão sexual. O subgrupo atingido, principalmente de início, foi o segmento populacional dos homossexuais masculinos e bissexuais. No ano de $1984,71 \%$ dos casos notificados eram de homens que fazem sexo com outros homens e bissexuais masculinos ${ }^{58}$. Todavia, após essa explosão inicial, sucedeu-se uma estabilização e, após alguns anos, uma redução na participação deste subgrupo populacional entre os casos notificados, em virtude de mudança de comportamento no sentido de práticas sexuais mais seguras.

A outra forma de transmissão clássica do HIV - exposição a sangue e derivados - teve um outro subgrupo bastante afetado, nos primeiros anos de epidemia: os hemofílicos. Muito destes foram contaminados por não existir, à época da explosão da epidemia, triagem sorológica do sangue a ser utilizado. Em 1984, este subgrupo representava $62 \%$ dos casos de exposição sangüinea ${ }^{58}$. Com a disponibilização de teste para detecção de anticorpos anti-HIV houve diminuição abrupta no número de hemofílicos contaminados com o decorrer do tempo, chegando hoje, de acordo com o último boletim epidemiológico, a uma taxa de 0,1\% deste subgrupo entre os casos de exposição sangüínea, no ano de $2002^{25}$.

Enquanto a infecção do HIV por transfusão sangüínea e derivados declinava entre a população geral e, principalmente, entre os hemofílicos, ascendia entre os UDI. A partir de meados da década de 1980, esta forma de transmissão ganha 
destaque dentro da forma de exposição sangüínea. De 1980 a 1990, 25,6\% dos casos de AIDS notificados no Brasil foram por esta categoria. Deste número, os UDI corresponderam a quase $80 \%$ dos casos. Para se ter uma idéia da elevação dos casos em UDI, em 1984 a participação era de apenas 37\% entre os casos de transmissão sangüínea, através de compartilhamento de agulhas e seringas ${ }^{58}$. No último boletim epidemiológico, os UDI já correspondem a praticamente todos casos $(99,2 \%)^{25}$.

Assim como nos EUA ${ }^{61}$, este comportamento de risco apresentou-se como um dos maiores responsáveis pelo alastramento da epidemia no Brasil, sobretudo nas Regiões Sul e Sudeste ${ }^{58}$, e se revelou como fonte primária da transmissão em heterossexuais e nos casos de transmissão perinatal ${ }^{62,63}$. Essa marcante participação dos UDI na disseminação do vírus desempenhou papel importante na expansão para municípios de pequeno e médio porte ${ }^{60}$.

Uma vez introduzido o vírus em uma comunidade de UDI, há uma disseminação rápida entre seus componentes com uma alta eficácia de transmissão ${ }^{64}$. Além de atuar na forma direta na transmissão do vírus, notou-se que as drogas injetáveis levavam ao sexo inseguro. Observou-se que esta inter-relação (drogas-sexo), devia-se a comportamento sexual de maior risco, como atividades sexuais com múltiplos parceiros ou diminuindo os cuidados de proteção durante a relação, ou seja, a não utilização de preservativos ${ }^{65,66}$.

Atualmente, a via de transmissão heterossexual é predominante no Brasil, e teve números crescentes desde 1980 até final da última década. Isso fez com que a AIDS, que outrora era confinada a "grupos populacionais de risco", disseminasse-se à população geral, em especial ao sexo feminino, com incidência crescente nos

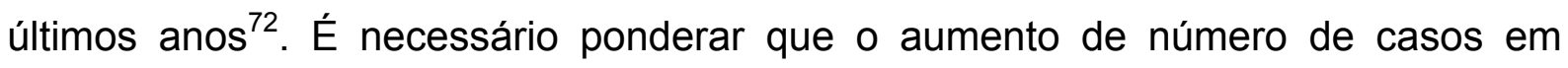
mulheres não é devido exclusivamente a transmissão heterossexual, sendo importante destacar o aumento de mulheres usuárias de drogas injetáveis ${ }^{67}$.

De 1980 a 1990 a contaminação por via heterossexual correspondeu a 61,9\% dos casos de AIDS, sendo que, deste número, 26,5\% foram em heterossexuais. Já em 2002, os heterossexuais corresponderam a $78 \%$ dos novos casos de AIDS contaminados por via sexual $^{25}$.

A expansão na quantidade de casos de AIDS por via heterossexual contribuiu de modo decisivo para o incremento de casos entre indivíduos do sexo feminino, acarretando uma alteração da razão homem:mulher, no sentido de uma participação 
proporcionalmente maior das mulheres ${ }^{67,68}$. A proporção entre homens e mulheres estreitou-se de 18:1 casos, em 1985, 9:1 em 1989 e 5:1 em 1992 ${ }^{71}$. Esta relação progrediu em decréscimo até estabilizar-se em 1:2 no ano de 1997, e já se inverteu em alguns municípios brasileiros ${ }^{58}$. Esta "feminização" $58,59,69,70$ cada vez mais evidente da AIDS parece envolver uma maior vulnerabilidade biológica da mulher ao HIV, e promove um incremento do risco de contaminação de gestantes. Noventa por cento dos casos registrados em indivíduos menores de 13 anos, em 1998/1999, foi devido a transmissão perinatal ${ }^{75}$.

Tendo alcançado dimensão claramente nacional, a epidemia de AIDS não se restringe mais aos grandes centros urbanos e atinge atualmente mais da metade dos quase cinco mil municípios brasileiros, com disseminação espacial maior, nos últimos anos, entre os municípios pequenos e mais pobres, se refletindo em uma interiorização ${ }^{59}$. Avançou durante a última década entre os indivíduos de menor escolaridade, inclusive invertendo a ordem com os de maior escolaridade ${ }^{73,74}$, e os de baixo poder socioeconômico ${ }^{76}$.

O Sistema de Vigilância Epidemiológica do Estado de São Paulo recebeu 110.845 notificações de casos de AIDS, desde 1980 até 30/09/2002. Destes, 81.454 pertencem ao sexo masculino e 29.391 ao sexo feminino, acarretando, razão de sexo de homem:mulher de 3:1. Vale lembrar que esta relação já chegou a um máximo de 27:1 na metade da década de 1980. O coeficiente de mortalidade da população geral vem diminuindo paulatinamente até 1995, e passa a ter quedas mais sensíveis a partir deste ano. Em relação à forma de exposição entre os homens, os casos entre homo e bissexuais somados $(27,6)$, são praticamente os mesmos dos casos entre UDI $(27,2 \%)$. Já entre os casos no sexo feminino o que predomina acentuadamente é a forma heterossexual $(61,8 \%)$, seguida pelas UDI $(18,1 \%)$. A cidade de São Paulo, em sua regional, é a área que concentra quase metade dos casos de todo o estado $(43,7 \%)^{86}$.

O primeiro caso de AIDS dignosticado na região de Ribeirão Preto data de 1984. Em 1985 e 1986 há o domínio de casos entre hemofílicos e os indivíduos de prática homo ou bissexual, com percentuais de notificação de $37 \%$ e $50 \%$, respectivamente. No decorrer da década de 80 vai ganhando destaque, com bastante intensidade, a forma de exposição sangüínea através dos UDI ${ }^{87}$. Este subgrupo ganhou tal importância epidemiológica que no final da década de 1980 era responsável por $44,5 \%$ dos casos, na região de Ribeirão Preto, enquanto no Estado 
de São Paulo era $21,9 \%$ e no Brasil $15,9 \%^{87}$. Na cidade de Ribeirão Preto, a partir de 1993, os percentuais atribuídos a esta forma de transmissão foram decrescendo, com ascendência para os heterossexuais, assim como no estado e no país ${ }^{22}$. A despeito disto, em 1997 os heterossexuais contavam 13\% das notificações e os UDI 22,5\%. Muito evidente neste município é o fato que, desde o início das notificações, a relação homem:mulher apresentou um padrão próprio, já iniciando com a cifra de 1:4, muito abaixo dos valores no estado, no Brasil e até em outros países, para o período. Este padrão diferenciado, segundo Menesia ${ }^{22}$, talvez se deva ao fato do elevado consumo de drogas ilícitas por ambos os sexos.

A regional de saúde de Ribeirão Preto ocupa a quinta colocação, no ranking do Estado de São Paulo, em casos notificados de AIDS $^{86}$. Já a cidade de Ribeirão Preto, em relação aos coeficientes de incidência e de mortalidade, ocupa a terceira e a quinta posição, respectivamente, no ano de $1999^{86}$.

Com o surgimento da infecção pelo HIV, novas diretrizes foram elaboradas para a prevenção das DSTs. A contaminação com este novo vírus fez com que as DSTs fossem diagnosticadas com maior freqüência ${ }^{9}$. Divulgação em massa dentro da sociedade civil foi necessária para esclarecer as formas de contágio deste "grande mal" do final do século XX, que afligia, principalmente, grupos de pessoas praticantes de determinados hábitos. Esta nova doença tornou-se disseminada, ganhando proporções maiores atingindo indistintamente mulheres e homens, mas percebeu-se que a epidemia não segue a mesma trajetória nas populações, apresentando-se de maneira distinta em cada área geográfica e afetando diferenciados segmentos populacionais. No Brasil, a situação reflete a diversidade sociogeográfica do país e sua marcante heterogeneidade regional, que faz da epidemia brasileira uma soma de pequenas epidemias regionais. Essas características e o dinamismo deste processo, além de dificultarem as atividades de acompanhamento do curso da epidemia, de prevenção da disseminação do HIV e do planejamento para reduzir o seu impacto, tornam indispensável um conhecimento mais profundo e preciso sobre a natureza da AIDS em cada região. A infecção pelo HIV é um reflexo de outras doenças infecto-contagiosas, onde indivíduos de menor nível sócio-cultural e de menos recursos econômicos são os que mais sofrem, ainda que todos possam potencialmente ser afetados.

Com formas de transmissão bem definidas, alguns tipos de populações ficaram mais susceptíveis a esta contaminação ${ }^{4}$. Desta forma, trabalhos específicos 
foram desenvolvidos para prevenção contra infecção pelo HIV em diferentes grupos de indivíduos, tais como: profissionais do sexo, UDI, homossexuais masculinos, presidiários, caminhoneiros, meninos de rua, etc.

No Brasil, segundo o Ministério da Justiça, existiam 284.989 presidiários até junho de 2003, sendo 95,6\% pertencentes ao sexo masculino. Estão distribuídos em 1431 estabelecimentos prisionais (penitenciárias, cadeias públicas, colônias agrícolas e outros) que não são suficientes, existindo um déficit de 104.263 vagas $^{27}$. O Estado de São Paulo, em junho de 2003, abrigava 41,5\% (118.389 indivíduos) de todos os presos do Brasil, sendo $94,7 \%$ do sexo masculino, e com um déficit de 43.659 vagas $^{27}$.

A cidade de Ribeirão Preto conta com duas unidades prisionais para indivíduos com penas já estabelecidas que são a Penitenciária de Ribeirão Preto e a Cadeia Pública de Vila Branca, hoje presídio feminino, além do Centro de Detenção Provisória (CDP). O total de encarcerados nestas prisões está por volta de 2000 pessoas.

Dentro destes espaços, em condições subumanas e na promiscuidade, ocorre toda a sorte de infecções e violências. Como conseqüência, a população prisional é considerada como sendo de alto risco para infecções relacionadas às condições de confinamento $^{21}$, como: tuberculose, sífilis, HIV, hepatites B e C e DSTs em geral ${ }^{4-}$ 10,13,88-90. Muitos destes indivíduos, freqüentemente, praticam sexo sem uso de preservativos em comportamento homossexual, compartilham seringas quando usam drogas ilícitas por via endovenosa ou tatuam suas peles sem boas condições de higiene. Fatores sociais como marginalização, baixo nível socioeconômico e deteriorização do sistema de saúde de nosso país auxiliam a alta disseminação destas doenças ${ }^{5,8}$.

Infecções oportunísticas foram, pela primeira vez, relatadas em prisioneiros de uma prisão estadual do Estado de Nova lorque, em agosto de $1982^{91}$. Alguns meses depois (março de 1983), o quadro clínico destes indivíduos foi descrito, agora já no contexto da síndrome da imunodeficiência adquirida, como pneumonia pelo Pneumocystis carinii e sarcoma de Kaposi em UDI ${ }^{28,92}$. Já nesta época, há 20 anos, o autor categorizava os presidiários como grupo de alto risco para o desenvolvimento da síndrome.

Por volta de meados da década de 1980, vários países europeus tornaram-se atentos com o aumento do número de presos infectados pelo HIV. Em alguns países 
como Bélgica, França e Alemanha, as autoridades da área de segurança estavam divididas em relação a diversas questões: Necessitam todos de triagem sorológica? Necessitam de isolamento para os infectados? Quais os riscos para os agentes carcereiros? Como tratar os doentes? ${ }^{93}$ Dessa maneira, diversos estudos foram realizados, desde então, com intuito de se medir a real extensão e causa da presença da AIDS entre os encarcerados.

A alta prevalência de infecção pelo HIV entre pessoas encarceradas tem sido encontrada em diferentes áreas geográficas ${ }^{3,5,11}$. Os EUA - país onde os primeiros casos de AIDS foram descritos, tanto na população geral quanto nos presidiários tinham em suas prisões 25.088 presos portadores do HIV ${ }^{94}$, em 2000. Neste país, a taxa de prevalência de infecção pelo HIV é 20 vezes maior entre os presos do que na população em geral ${ }^{12}$. Em 1999, nas prisões americanas, 2,1\% dos detentos eram portadores do $\mathrm{HIV}^{23}$.

De janeiro de 1994 a dezembro de 1996, 220 mil pessoas foram reportadas com a Síndrome da Imunodeficiência Adquirida (AIDS), nos EUA. Destas, 9.370 $(4 \%)$ estavam encarceradas à época do diagnóstico ${ }^{3}$. Ainda nos EUA, prisões do estado de Maryland tiveram $3 \%$ de prevalência para a população carcerária ${ }^{12}$.

Prevalências variáveis foram encontradas em outros países: República da Irlanda ${ }^{14}$, taxa de 2\%; Marselha, na França ${ }^{15}$, 6\%; Áustria ${ }^{96}, 1,3 \%$; Tijuana, no México $^{97}, 1,2 \%$ e em Maputo, Moçambique, taxa de $0,6 \%{ }^{6}$. Já em prisões da Zâmbia, este valor salta para $25 \%$, inclusive bem maior do que a estimativa de prevalência na população geral adulta, que é de $19 \%{ }^{24}$; e na Espanha é encontrado $24,6 \%{ }^{95}$.

Em nosso país, o tema já vem sendo estudado desde o final da década de 1980. Em um estudo realizado entre dezembro de 1993 e abril de 1994, na Casa de Detenção de São Paulo, foi encontrada prevalência de $16 \%$ para $\mathrm{HIV}^{5}$, em uma das pesquisas de maior percentual entre os presos. Em prisão no interior de Minas Gerais, em 3,2\% de 63 detentos foi diagnosticada sorologia positiva para o $\mathrm{HIV}^{8}$. No ano de 1987, um estudo feito em 923 prisioneiros de São Paulo mostrou uma soroprevalência de $12,5 \%{ }^{11}$. Estudo na cadeia de Suzano-SP apresentou índice de $7,5 \%$ em 134 amostras $^{111}$. Na cidade de Sorocaba-SP ocorreu prevalência de 12,6\% em 1059 presos $^{104}$. No complexo penitenciário de Campinas-SP, uma pesquisa em 693 amostras de sangue mostrou $14,4 \%{ }^{17}$ e em Fortaleza-CE encontrou-se uma prevalência de $1,64 \%{ }^{18}$. 
Outro grupo de confinados em instituições de recuperação e inserção social são os menores infratores. Estes, em grande parte adolescentes, estão bastante vulneráveis à infecção pelo HIV. Primeiramente porque, quando estão soltos, vivem à mercê da própria sorte, sofrendo diversos tipos de abusos e violência. Já encarcerados, estão confinados e detém os mesmos problemas dos adultos: promiscuidade, violência sexual, uso de drogas, etc. Em 1999, um trabalho realizado em dois centros da Fundação para o Bem Estar de Menor (FEBEM), revelou antiHIV reagente em $2,6 \%$ de 1122 menores $^{16}$.

A explosão das DSTs e, principalmente, a epidemia de HIVIAIDS tem mobilizado governo e sociedade civil em busca de estratégias eficazes para seu controle. A disseminação de doenças infecciosas em prisões é uma preocupação real de todos profissionais de saúde que trabalham na área preventiva. A situação de confinamento, nos moldes do nosso atual sistema carcerário, constitui uma condição sanitária de difícil controle, uma vez que atinge milhares de pessoas que entram para cumprir pena e retornam à sociedade de forma contínua, além das que trabalham nestas instituições e as que as visitam.

As altas taxas de HIV entre os encarcerados, comparado com a população em geral, indicam que programas de prevenção devem ser instituídos o quanto $a^{2}{ }^{20}$. Esta desproporção entre presidiários e o restante da população pode ocorrer em parte porque os primeiros são constituídos de indivíduos que praticam crimes que podem levar a um contato com sangue ou outros líquidos corporais das vítimas $^{4}$. Uma vez na prisão, estes presos podem atuar como vetores transmissores do HIV, para outros presos, principalmente, através de contato homossexual e compartilhamento de agulhas nos UDI. Isto já foi evidenciado em diferentes análises que pesquisaram a soroprevalência do HIV em prisões e encontraram fortes evidências de transmissão do vírus dentro do sistema penal ${ }^{19,98-103,105-110}$.

No Brasil, a epidemia de AIDS na população prisional não está sendo tratada da forma mais adequada por nossas autoridades há vários anos. A falta de definições centralizadas para a abordagem deste problema enfatiza a necessidade de realização de estudos de abrangência nacional que permitam a elaboração de estratégias eficazes para seu controle.

A ausência de uma ação de aconselhamento dentro do sistema prisional contribui para o incremento da infecção pelo HIV. Esta prática consistiria em uma estratégia de prevenção que atuaria no âmbito do indivíduo, ou seja, trabalharia com 
a identificação do próprio risco e propiciaria uma reflexão sobre medidas preventivas viáveis para o atendimento ao indivíduo. Através do aconselhamento, o preso teria acesso a orientações para a promoção de ações educativas, para conhecimento de formas de transmissão, prevenção e tratamento das DSTs, levando à adoção de práticas mais seguras. Portanto, se torna urgente uma penetração, ainda maior do que já existe, em todo sistema prisional brasileiro, para levar adiante um programa de assistência e prevenção de qualidade. Para isso, se faz necessário promover estudos sobre perfil epidemiológico desta população nas maiores unidades penitenciárias deste país.

O único trabalho existente em Ribeirão Preto foi realizado na Cadeia Pública de Vila Branca em 1996. Apesar de não ficar bem claro a metodologia do estudo, este mostrou 24 (5,8\%) portadores de AIDS em 411 presos $^{112}$. Na penitenciária de Ribeirão Preto existe um número considerável de presos (aproximadamente 50 indivíduos), que faz acompanhamento médico por conta do HIV. Há um estimável número de presos e uma ausência de um trabalho de busca ativa sorológica para o HIV, apesar do bom trabalho de assistência aos pacientes portadores, feito pela administração do presídio em parceria com o Programa de DST/AIDS da Secretaria de Saúde de Ribeirão Preto. Torna-se necessário, já que nenhum estudo semelhante tenha sido feito nesta instituição, a determinação do perfil sorológico desta unidade para realização de medidas preventivas e assistenciais. 


\section{OBJETIVOS}

Na população carcerária masculina da Penitenciária de Ribeirão Preto, este estudo objetiva:

1. Estimar a prevalência de infecção pelo HIV.

2. Investigar os fatores de riscos para infecção pelo HIV. 


\section{MATERIAL E MÉTODOS}

\subsection{Modelo de Estudo}

Este estudo foi realizado utilizando-se o modelo transversal.

\subsection{Divisão da População Carcerária}

A penitenciária de Ribeirão Preto divide seus 1.030 presidiários (número de maio de 2003) em basicamente três ambientes:

A. Pavilhões. São em número de quatro e abrigam mais de $80 \%$ dos presos em regime fechado, assim distribuídos:

$\begin{array}{lll}\text { Pavilhão I } & 189 & \text { presos. } \\ \text { Pavilhão II } & 234 & \text { presos. } \\ \text { Pavilhão III } & 236 \text { presos } \\ \text { Pavilhão IV } & 234 \text { presos } \\ \text { Total } & 893 \text { presos }\end{array}$

B. "Seguro". Ala dos presos que correm risco de vida e necessitam de isolamento. Contava com 30 presos.

C. Ala de progressão continuada (APP). Área que contém os presos que saem do regime fechado dos pavilhões para o semi-aberto. Existiam 107 presos.

\subsection{População de Referência}

A população de referência foi representada pela totalidade dos 893 presidiários confinados em regime de prisão fechada nos 4 pavilhões da Penitenciária Ribeirão Preto, no início do estudo, em maio de 2003. 


\subsection{População de Estudo e Tamanho Amostral}

A partir da população de referência foi realizada uma amostragem de presidiários, com base na fórmula utilizada para determinação do $n$ em levantamentos:

$$
n=\frac{Z^{2} P Q}{d^{2}}
$$

onde:

$\mathrm{n}=$ tamanho amostral mínimo;

$Z$ = variável reduzida, cujo valor para um alfa de 0,05 é 1,96;

$\mathrm{P}=$ prevalência estimada de se encontrar o fenômeno estudado;

$Q=$ complemento da prevalência estimada $(1-P)$;

$\mathrm{d}$ = precisão desejada, ou seja, a diferença admitida entre a verdadeira prevalência e a prevalência estimada pela pesquisa.

De acordo com estudos anteriores em outras penitenciárias brasileiras, o $\mathrm{P}$ foi definido baseado na prevalência de infecção pelo HIV da ordem de 15,0\%. Para a precisão desejada (d), visando uma compatibilização com os recursos disponíveis, empregou-se o valor de 4.

Assim sendo, assumindo um alfa de 0,05, uma precisão (d) de 4 e uma prevalência estimada de infecção pelo HIV da ordem de 15,0\%, o tamanho amostral mínimo determinado foi de 306 indivíduos. Ao final, participaram do estudo 333 indivíduos, que constituíram a população de estudo.

Empregando-se um processo de amostragem casual simples, foram sorteados 100 presos de cada um dos quatro pavilhões. Destes 400, concordaram em participar do estudo 333 presos, no período de 13 de maio a 14 de agosto de 2003, assim distribuídos:

$\begin{array}{ll}\text { Pavilhão I } & 87 \text { presos } \\ \text { Pavilhão II } & 83 \text { presos } \\ \text { Pavilhão III } & 86 \text { presos } \\ \text { Pavilhão IV } & 77 \text { presos } \\ \text { Total } & 333 \text { presos }\end{array}$




\subsection{Critérios de Inclusão}

Foram incluídos todos os presidiários sorteados que manifestaram concordância em participar da pesquisa mediante assinatura de um termo de consentimento livre, após tomar conhecimento dos seus objetivos e metodologia.

\subsection{Critérios de Exclusão}

Foram inicialmente excluídos os presos do "seguro" - por questão de segurança dos próprios - e os da APP, por serem de alta rotatividade e se alojarem em área de difícil acesso ao local da realização do estudo. Dos presos sorteados, foram excluídos apenas os que se recusaram a participar do estudo, após tomar conhecimento dos seus objetivos e metodologia.

\subsection{Localização da Penitenciária e Local do Estudo}

O presente estudo foi realizado na Penitenciária de Ribeirão Preto, situado na Rodovia Abrão Assed (SP-333), KM 47, em Ribeirão Preto-SP. Esta unidade prisional conta com salas individuais destinadas para atendimento médico, odontológico e cuidados de enfermagem. Nesta área há duas salas de ambulatório para atendimento médico, uma sala devidamente equipada para atendimento odontológico, um posto de coleta de exames laboratoriais e um posto de enfermagem, com salas para administrar medicamentos e para realização de curativos. O local conta ainda com oito celas individuais para presos que necessitem ficar em isolamento por algum problema médico diagnosticado.

\subsection{Coleta de Informações}

Foram fornecidas a todos os presos contatados, em linguagem acessível, informações sobre DSTs, AIDS, hepatites B e C: principais aspectos de transmissão e evolução, riscos associados a diferentes práticas sexuais e importância do diagnóstico sorológico. Aos participantes com sorologia reagente ao HIV, garantia-se atendimento médico especializado no ambulatório de DST/AIDS do Posto do Castelo Branco, da rede municipal. Para os presidiários diagnosticados com sífilis, o tratamento seria feito no serviço médico da própria penitenciária. Àqueles que concordaram em participar, solicitou-se leitura do termo de consentimento (Apêndice 1), seguido de assinatura. Em seguida o participante foi submetido à aplicação de questionário específico (Apêndice 2), realizado pelo próprio pesquisador, garantindo- 
se sigilo absoluto de todas as informações coletadas, bem como dos resultados sorológicos, acordado em termo de consentimento. O questionário foi aplicado na dependência destinada à aplicação de medicamentos.

\subsection{Variáveis Estudadas Através do Questionário}

Foram estudadas 38 variáveis, a seguir discriminadas:

3.9.1 Nome: identificação verdadeira do participante, idêntica à lista fornecida pela administração da penitenciária.

3.9.2 Nascimento e idade: dia, mês e ano do nascimento e idade completa.

3.9.3 Estado civil: codificado como:

1. casado

2. solteiro

3. amasiado

4. viúvo

5. divorciado/separado

3.9.4 Filhos: número total de filhos do participante

3.9.5 Local de nascimento: codificado como:

1.

2. $\quad$ região de Ribeirão Preto

3. outra região do Estado de São Paulo

$4 . \quad$ outro estado.

3.9.6 Local de residência: anotado de modo análogo ao item 3.9.5.

3.9.7 Escolaridade: tempo de estudo do participante, assim codificado:

1. nenhuma

2. até 2 anos

3. 2 a 5 anos

4. 5 a 8 anos

5. colegial incompleto

6. colegial completo

7. superior incompleto

8. superior completo.

3.9.8 Tempo total da pena: período total do encarceramento do participante. 
3.9.9 Tempo já cumprido: tempo contado a partir da prisão do participante até o momento do estudo.

3.9.10 Internação em reformatório/FEBEM: internação em instituições corretivas quando o participante era menor de idade, assim codificado:

1. $\operatorname{sim}$

2. não

3. não sabe

3.9.11 Antecedentes de doenças sexualmente transmissíveis (DSTs) do tipo ulcerativa: qualquer episódio de uma ou mais DST com úlcera, assim codificado:

1. não

2. uma vez

3. mais de uma vez

3.9.12 Tratamento das DSTs do tipo ulcerativa: se houve por parte do participante tratamento das DSTs do tipo ulcerativa, e onde tratou, de acordo com as opções:

1. médico

2. não tratou

3. não se aplica

4. farmácia

3.9.13 Antecedentes de DSTs do tipo não ulcerativa: qualquer episódio de uma ou mais DST sem úlcera, seguindo as opções:

1. não

2. uma vez

3. mais de uma vez.

3.9.14 Tratamento das DSTs do tipo não ulcerativa: se houve por parte do participante tratamento das DSTs do tipo ulcerativa, e onde tratou, de acordo com as opções:

1. médico

2. não tratou

3. não se aplica

4. farmácia

3.9.15 Circuncisão: o participante já realizou cirurgia de postectomia, apresentando as opções:

1. $\operatorname{sim}$

2. não

3.9.16 Tatuagem: o participante tinha realizado e/ou apresentava tatuagem. As respostas classificadas em:

1. $\operatorname{sim}$

2. não 
3.9.17 Piercing: o participante tinha realizado e/ou apresentava piercing. As respostas foram classificadas como:

1. $\operatorname{sim}$

2. não

3.9.18 Sorologia para o HIV previamente: o participante já realizou exame para HIV e quantas vezes. As opções de resposta foram classificadas em:

1. não

2. uma vez

3. mais de uma vez

4. não sabe

3.9.19 Resultado da sorologia para HIV previamente: se o participante realizou sorologia para HIV previamente, qual seu resultado. As respostas foram classificadas como:

1. positivo

2. negativo

3. não sabe

4. não se aplica

3.9.20 Transfusão: se o participante tinha recebido transfusão de sangue. As respostas foram classificadas em:

1. não

2. uma vez

3. mais de uma vez

4. não sabe

3.9.21 Relacionamento sexual com usuários de drogas ilícitas: o participante teve relação sexual com alguma pessoa que tivesse usado algum tipo de droga ilícita. As respostas foram definidas como:

1. $\operatorname{sim}$

2. não

3.9.22 Uso de drogas ilícitas não injetáveis agora ou no passado: consumo atual ou passado de drogas ilícitas não injetáveis; se a resposta fosse afirmativa, especificar nome (s). As respostas foram classificadas em:

1. $\operatorname{sim}$

2. não

3. não sabe

3.9.23 Uso de drogas ilícitas injetáveis no passado: consumo no passado de drogas ilícitas injetáveis, classificado em:

1. freqüentemente

2. às vezes

3. raramente

4. uma vez

5. nunca

6. não se aplica 
3.9.24 Tempo de uso de drogas ilícitas injetáveis no passado: se o participante fez uso de drogas injetáveis por quanto tempo. As opções foram:

1. mais de 5 anos

2. 3 a 5 anos

3. 1 a 3 anos

4. menos de um ano

5. não se aplica.

3.9.25 Compartilhamento no passado de agulhas ou seringas: uso compartilhado de agulhas e/ou seringas para injetar drogas ilícitas no passado. As opções foram classificadas como:

1. freqüentemente

2. às vezes

3. raramente

4. uma vez

5. nunca

6. não se aplica

3.9.26 Uso atual de drogas ilícitas injetáveis: consumo atual de drogas ilícitas injetáveis, assim codificadas:

1. freqüentemente

2. às vezes

3. raramente

4. uma vez

5. nunca

6. não se aplica.

3.9.27 Compartilhamento atual de agulhas ou seringas: uso compartilhado de agulhas e/ou seringas para injetar drogas ilícitas atualmente. As opções foram classificadas como:

1. freqüentemente

2. às vezes

3. raramente

4. uma vez

5. nunca

6. não se aplica

3.9.28 Preferência sexual: o participante tem preferência por qual sexo. As respostas foram classificadas em:

1. heterossexual

2. homossexual

3. bissexual

4. desconhecido

3.9.29 Quantos parceiros teve um ano antes da prisão: número de parceiros com quem o participante teve relação sexual um ano antes da prisão. 
3.9.30 Visita íntima: se o participante tem visita íntima com parceiro (a). As opções foram assim codificadas:

1. $\operatorname{sim}$

2. não

3.9.31 Uso de preservativo na visita íntima: freqüência de uso de preservativo, pelo participante nas relações sexuais da visita íntima, classificada em:

1. sempre

2. às vezes;

3. nunca

4. não se aplica

3.9.32 Sexo com colegas na prisão: se o participante tem relações sexuais com colegas da prisão. As respostas foram codificadas em:

1. freqüentemente

2. às vezes

3. raramente

4. uma vez

5. nunca

6. não sabe

3.9.33 Forma de sexo com os colegas: Tipo de sexo praticado entre o participante e colegas, classificado da seguinte maneira:

1. ativo

2. passivo

3. ativo/passivo

4. só oral

5. só masturbação

6. não se aplica

3.9.34 Uso de preservativo em relação sexual com os colegas: freqüência de uso de preservativo nas relações sexuais com colegas, classificada em:

1. sempre

2. às vezes

3. nunca

4. não se aplica

3.9.35 Antecedentes de icterícia: se o participante tinha apresentado no passado evidências de icterícia. As respostas foram classificadas em:

1. $\operatorname{sim}$

2. não

3. não sabe

3.9.36 Antecedentes de hepatite: se o participante tinha apresentado no passado manifestações clínicas de hepatite, segundo ele próprio. As respostas foram classificadas em:

1. $\operatorname{sim}$

2. não

3. não sabe 
3.9.37 Tabagismo: se o participante fuma cigarros atualmente. As respostas foram classificadas em:

1. $\operatorname{sim}$

2. não

3. não sabe

\subsection{Coleta de Sangue}

Para a coleta de sangue, foram utilizadas agulhas descartáveis e dois tubos do tipo vacutainer, sendo um com capacidade de $5 \mathrm{ml}$, para sorologias do HIV e sífilis, e outro de $10 \mathrm{ml}$, para sorologias de hepatite B e C. Cada tubo foi identificado com as iniciais dos respectivos nomes e com o número de ordem do questionário aplicado. As amostras foram coletadas, na grande maioria, na semana seguinte à aplicação do questionário, em dia próprio para a coleta. O sangue foi colhido por auxiliar de enfermagem, funcionária concursada da penitenciária e, posteriormente, por enfermeira graduada. Todo material de consumo utilizado para obtenção destas amostras foi adquirido pelo Programa de DST/AIDS da Secretaria de Saúde de Ribeirão Preto.

Após a coleta, as amostras foram armazenadas em caixa de isopor, dentro da qual havia estantes de madeira projetadas especialmente para permitir que os tubos permanecessem em uma inclinação de aproximadamente $15^{\circ}$, para facilitar a retração do coágulo e possibilitar melhor rendimento do soro de cada amostra. $\mathrm{O}$ isopor era mantido refrigerado com barras de gelo reciclável, colocadas entre as estantes.

Terminada a coleta, as amostras eram encaminhadas, pelo próprio pesquisador, ao laboratório de referência de sorologias para DSTs da Secretaria de Saúde de Ribeirão Preto, no posto de saúde do Castelo Branco, onde eram deixados os tubos com sangue para a realização das sorologias do HIV e sífilis. O restante era conduzido ao Hospital das Clínicas da Faculdade de Medicina de Ribeirão Preto da Universidade de São Paulo (HCFMRP-USP), onde foram centrifugados e estocados para serem enviados ao Centro de Referência Nacional de Hepatites Virais do Instituto Oswaldo Cruz (Fiocruz). 


\subsection{Análise Sorológica}

A sorologia do HIV é a única analisada na presente pesquisa. As demais sífilis, hepatite B e C - serão objeto de estudos futuros.

No laboratório, as amostras foram centrifugadas a $3.000 \mathrm{rpm}$, durante 10 minutos. Duas alíquotas de soro de cada amostra foram armazenadas em tubo tipo eppendorf, identificados com numeração própria do laboratório e estocados em freezer a $20^{\circ} \mathrm{C}$ negativos.

Para detecção de anticorpos anti-HIV-1, seguiram-se as orientações do Ministério da Saúde, através da Portaria número 59 de 28 de janeiro de 2003, divididas em 3 etapas:

Etapa I - Triagem sorológica. Consiste na realização de um teste imunoenzimático (ELISA), capaz de detectar anticorpos anti-HIV-1 e anti-HIV-2. O ELISA utilizado não poderá ser de avaliação rápida (teste rápido). As amostras não reagentes serão definidas como negativa para o HIV. As amostras reagentes nesta etapa são submetidas a um segundo ELISA - com princípio metodológico e/ou antígenos distintos do primeiro ELISA utilizado - em paralelo ao teste de imunofluorescência indireta (IFI) para HIV-1 ou ao teste imunoblot para HIV. Aquelas com resultados discordantes ou indeterminados são submetidas diretamente ao teste Western Blot. As duas etapas seguintes são realizadas no Instituto Adolfo Lutz de Ribeirão Preto.

Etapa II - Consiste na confirmação sorológica por teste de IFI para o HIV-1 em paralelo ao segundo ELISA. Estes dois testes reagentes são definidos como "amostra positiva para HIV-1".

Etapa III - Baseia-se na confirmação sorológica pela realização do teste Western blot. $\mathrm{Na}$ interpretação deste exame são observados os seguintes critérios:

a) amostra reagente: quando há presença de, no mínimo, duas bandas dentre: gp 160/120; gp 41; p 24. O resultado é definido como amostra positiva ao HIV-1.

b) amostra não reagente: ausência de bandas, tendo seu resultado definido como amostra negativa ao HIV-1. Neste caso a amostra deve ser submetida à investigação de anticorpos para o HIV-2.

c) amostra indeterminada: qualquer outro padrão de bandas diferente dos descritos anteriormente. O resultado é definido como amostra indeterminada ao HIV-1, devendo ser submetida à investigação de anticorpos para o HIV-2. Uma nova coleta é feita após 30 dias com o propósito de verificar a possível ocorrência de 
soroconversão recente.

Para todas as amostras liberadas com resultado reagente (positivo) nas etapas confirmatórias (II ou III), é obrigatória a coleta de uma nova amostra de sangue para repetição da etapa I, com o objetivo de confirmar a positividade da primeira amostra. Caso os resultados desta segunda amostra sejam não reagentes ou indeterminados, são novamente realizadas todas as etapas acima seqüenciadas.

\subsection{Descrição dos Métodos Sorológicos}

Serão descritos os métodos ELISA e imunofluorescência indireta (IFI). Não foi necessário a realização do método Western blot.

\section{- Teste imunoenzimático (ELISA):}

Foi utilizado o reativo Enzygnost $₫$ Anti-HIV 1/2 Plus, produzido pela Dade Behring. As imunoglobulinas HIV específicas contidas na amostra ligam-se às proteínas recombinantes dos HIV-1, HIV-2 e/ou HIV 1 (subtipo) fixadas à superfície da placa de microtitulação. Após eliminação dos componentes não ligados, o complexo conjugado é ligado aos anticorpos HIV específicos.

Após eliminação do conjugado em excesso, é interrompida por adição da solução para bloqueio POD (reação cromática amarela). A intensidade da cor é proporcional à concentração de anticorpos na amostra. O processamento do teste imunoenzimático efetua-se com os processadores ELISA BEP® II, BEP® III e BEP® 2000.

Definiu-se o ponto de corte (cutoff), tirando o valor médio de todos os valores de extinção (positivos e negativos) válidos e em seguida somando-se ao valor de 0,400 .

\section{- Teste de Imunofluorescência Indireta (IFI):}

Este ensaio consiste na reação de soros ou plasmas humanos com células K37-3, infectadas pelo $\mathrm{HIV}_{1}$, fixadas em lâminas de microscopia para fluorescência. Aproximadamente $25,0 \%$ a $35,0 \%$ das células possuem antígenos virais capazes de ser detectados em sua superfície. A reação entre o antígeno fixado e o anticorpo presente nas amostras é visualizada após a adição de anti-imunoglobulina humana conjugada com isotiocianato de fluoresceína.

Na leitura desta reação foi utilizado um microscópio para fluorescência Nikon, tipo Labophot-2. 
Obteve-se o resultado comparando o background de fluorescência do soro controle negativo, fornecido pelo fabricante, com o do soro em teste. Foi considerada amostra positiva (reagente) aquela com fluorescência maior que o background observado no controle negativo, e negativa (não reagente), a que apresentou fluorescência semelhante ao background negativo.

De todas as amostras reagentes ao teste de IFI foi colhida uma segunda amostra de sangue, e repetida a etapa I para confirmação da positividade da primeira amostra.

\subsection{Digitação e Organização dos Dados}

Os dados da pesquisa foram digitados pelo próprio autor, criando-se um banco de dados no Programa EPIINFO $6.04^{200}$, que posteriormente foram transferidos para o Programa STATA $6.0^{201}$.

\subsection{Análise Estatística}

As possíveis associações entre as variáveis qualitativas ou quantitativas estratificadas e a presença do marcador para o HIV foram testadas inicialmente através de uma análise univariada, pelo teste do $\chi^{2}$. Nas ocasiões em que o teste não pode ser aplicado, em razão do reduzido número de participantes, optou-se pelo teste exato de Fischer. Estas análises foram realizadas através do pacote STATA na sua versão $6.0^{201}$.

As variáveis que na análise univariada apresentaram um valor de "p" igual ou inferior a 0,25 foram selecionadas para uma análise multivariada, através de um modelo de regressão logística baysiano.

\subsection{Aspectos Éticos}

O presente projeto foi aprovado pelo Comitê de Ética e Pesquisa do HCFMRP-USP, em sua $152^{a}$ Reunião Ordinária realizada em 28/04/2003. 


\section{RESULTADOS}

\subsection{Aspectos Descritivos da População de Estudo}

Inicialmente, responderam ao questionário e assinaram 0 termo de participação 345 presos. Contudo, somente 333 colheram amostras de sangue, tendo ocorrido 12 desistências no momento da coleta.

As tabelas de 1 a 10 são apenas descritivas e mostram características gerais da população estudada. As tabelas seguintes representam a análise da distribuição da sorologia do HIV, de acordo com diferentes variáveis, e constituem o estudo da associação entre a presença dessa infecção e seus possíveis fatores preditores.

Conforme pode ser visto na Tabela 1, existia no início dessa investigação um total de 893 presidiários dispostos em 4 pavilhões, com uma distribuição numérica muito semelhante em três deles (2, 3 e 4) e um valor menor no outro (189). Os 333 participantes desse estudo representam $37,3 \%$ do total de presidiários inicialmente encontrados nos 4 pavilhões, com um predomínio percentual de participação dos residentes no pavilhão $1(46,0 \%)$ e uma distribuição que oscilou entre $32,9 \%$ e $36,4 \%$ nos demais. Vale frisar que existiam ainda outros 138 presidiários, incluindose os do "seguro" e os da ala de progressão continuada (APP), perfazendo um total de 1030 pessoas. Assim, o percentual de participação em relação à totalidade da população do presídio foi igual a 32,3\% (333/1030). 
Tabela 1 - Distribuição dos presidiários nos pavilhões estudados e seus respectivos participantes. Penitenciária de Ribeirão Preto, 2003.

\begin{tabular}{cccc}
\hline \multirow{2}{*}{ PAVILHÃO } & $\begin{array}{c}\text { NÚMERO DE } \\
\text { PRESIDIÁRIOS }\end{array}$ & \multicolumn{2}{c}{ PARTICIPANTES } \\
\cline { 3 - 4 } & 189 & 87 & $\%$ \\
\hline 1 & 234 & 83 & 35,5 \\
2 & 236 & 86 & 36,4 \\
3 & 234 & 77 & 32,9 \\
4 & 893 & 333 & 37,3 \\
\hline Total & & &
\end{tabular}

Em relação a variável idade (Tabela 2), os presidiários apresentam uma média de 30,1 anos e desvio padrão de 8,2. A mediana é de 28 anos e a amplitude de variação mostrou-se consideravelmente larga, variando de 19 a 69 anos.

Tabela 2 - Valores da média, desvio padrão, mediana e amplitude de variação da idade nos presidiários. Penitenciária de Ribeirão Preto, 2003.

IDADE $\quad$ PRESIDIÁRIO

Média 30,06

Desvio padrão $\quad 8,18$

Mediana 28

Amplitude de variação $\quad 19$ a 69

O estudo dos participantes segundo o pavilhão e o grupo etário (Tabela 3) revela uma concentração nos grupos de 25 a 30 anos (32,1\%) e de 19 a 24 anos $(28,9 \%)$, mostrando que até os 30 anos de idade concentram-se mais de $60 \%$ deles. Os grupos de 31 a 35 e de 36 a 45 anos participam com percentuais menores e muito próximos entre si $(16,5 \%$ e $18 \%$, respectivamente). No extremo superior de idade (>45 anos) observa-se o mais baixo percentual de participação $(4,5 \%)$. A superioridade do grupo de 25 a 30 se dá, predominantemente, nos pavilhões 1 e 2 (32,2\% e 34,9\%, respectivamente). Por outro lado, o grupo de 19 a 24 anos tem uma participação maior nos pavilhões 3 e 4 (34,9\% e 6,3\%, respectivamente). 
Tabela 3 - Distribuição dos presidiários segundo idade e pavilhão. Penitenciária de Ribeirão Preto, 2003.

\begin{tabular}{|c|c|c|c|c|c|c|c|c|c|c|}
\hline \multirow{3}{*}{$\begin{array}{l}\text { FAIXA } \\
\text { ETÁRIA }\end{array}$} & \multicolumn{10}{|c|}{ PAVILHÃO } \\
\hline & \multicolumn{2}{|r|}{1} & \multicolumn{2}{|r|}{2} & \multicolumn{2}{|r|}{3} & \multicolumn{2}{|c|}{4} & \multicolumn{2}{|c|}{ Total } \\
\hline & $\mathrm{n}$ & $\%$ & $\mathrm{n}$ & $\%$ & $\mathrm{n}$ & $\%$ & $\mathrm{n}$ & $\%$ & $\mathrm{n}$ & $\%$ \\
\hline $19-24$ anos & 17 & 19,6 & 21 & 25,3 & 30 & 34,9 & 28 & 36,3 & 96 & 28,9 \\
\hline $25-30$ anos & 28 & 32,2 & 29 & 34,9 & 27 & 31,4 & 23 & 29,9 & 107 & 32,1 \\
\hline $31-35$ anos & 13 & 14,9 & 15 & 18,1 & 16 & 18,6 & 11 & 14,3 & 55 & 16,5 \\
\hline $36-45$ anos & 23 & 26,4 & 16 & 19,3 & 11 & 12,8 & 10 & 13,0 & 60 & 18,0 \\
\hline$>45$ anos & 06 & 6,9 & 02 & 2,4 & 02 & 2,3 & 05 & 6,5 & 15 & 4,5 \\
\hline Total & 87 & 100,0 & 83 & 100,0 & 86 & 100,0 & 77 & 100,0 & 333 & 100,0 \\
\hline
\end{tabular}

A Tabela 4 mostra que a maioria dos participantes nasceu em cidades da região de Ribeirão Preto $(31,6 \%)$, seguida dos nascidos em outra região do Estado de São Paulo $(24,6 \%)$ e nos outros estados do País (22,5\%). Nascidos em Ribeirão Preto representam $21,3 \%$ dos participantes, concentrando-se de modo mais evidente no pavilhão $1(28,7 \%)$, quando comparado aos demais.

Tabela 4 - Distribuição dos presidiários segundo local de nascimento e pavilhão. Penitenciária de Ribeirão Preto, 2003.

\section{PAVILHÃO}

\begin{tabular}{|c|c|c|c|c|c|c|c|c|c|c|}
\hline \multirow[t]{2}{*}{$\begin{array}{c}\text { LOCAL DE } \\
\text { NASCIMENTO }\end{array}$} & & \multicolumn{2}{|r|}{2} & \multicolumn{2}{|c|}{3} & \multicolumn{2}{|c|}{4} & \multicolumn{2}{|c|}{ Total } \\
\hline & $\mathrm{n}$ & $\%$ & $\mathrm{n}$ & $\%$ & $\mathrm{n}$ & $\%$ & $\mathrm{n}$ & $\%$ & $\mathrm{n}$ & $\%$ \\
\hline $\begin{array}{l}\text { Ribeirão Preto } \\
\text { Região de }\end{array}$ & 25 & 28,7 & 16 & 19,3 & 16 & 18,6 & 14 & 18,2 & 71 & 21,3 \\
\hline $\begin{array}{l}\text { Ribeirão Preto } \\
\text { Outra reqião de }\end{array}$ & 25 & 28,7 & 27 & 32,5 & 28 & 32,6 & 25 & 32,4 & 105 & 31,6 \\
\hline São P & 18 & 20,7 & 20 & 24,1 & 22 & 25,6 & 22 & 28,6 & 82 & 24,6 \\
\hline Outro estado & 19 & 21,9 & 20 & 24,1 & 20 & 23,2 & 16 & 20,8 & 75 & 22,5 \\
\hline Total & 87 & 100,0 & 83 & 100,0 & 86 & 00,0 & 77 & 100,0 & 333 & 100,0 \\
\hline
\end{tabular}


Analisando-se o local de residência (Tabela 5), verifica-se que apenas $3 \%$ têm moradia fixada fora do Estado de São Paulo e 21,3\% em outras regiões do Estado. Chama atenção que mais de três quartos dos participantes moram em Ribeirão Preto e região ( $34,8 \%$ na cidade e $40,9 \%$ na região). A distribuição dentro dos pavilhões evidencia predomínio dos que residem na cidade de Ribeirão Preto, entre os habitantes do pavilhão 1 (54,0\%).

Tabela 5 - Distribuição dos presidiários segundo local de residência e pavilhão. Penitenciária de Ribeirão Preto, 2003.

\section{PAVILHÃO}

\begin{tabular}{|c|c|c|c|c|c|c|c|c|c|c|}
\hline \multirow[t]{2}{*}{$\begin{array}{l}\text { LOCAL DE } \\
\text { RESIDÊNCIA }\end{array}$} & \multicolumn{2}{|r|}{1} & \multicolumn{2}{|c|}{2} & \multicolumn{2}{|r|}{3} & \multicolumn{2}{|c|}{4} & \multicolumn{2}{|c|}{ Total } \\
\hline & $\mathrm{n}$ & $\%$ & $\mathrm{n}$ & $\%$ & $\mathrm{n}$ & $\%$ & $n$ & $\%$ & $\mathrm{n}$ & $\%$ \\
\hline $\begin{array}{l}\text { Ribeirão Preto } \\
\text { Região de }\end{array}$ & 47 & 54,0 & 27 & 32,5 & 23 & 26,8 & 19 & 24,7 & 116 & 34,8 \\
\hline $\begin{array}{l}\text { Ribeirão Preto } \\
\text { Outra região }\end{array}$ & 28 & 32,2 & 34 & 41,0 & 43 & 50,0 & 31 & 40,2 & 136 & 40,9 \\
\hline de São Paulo & 11 & 12,6 & 18 & 21,7 & 18 & 20,9 & 24 & 31,2 & 71 & 21,3 \\
\hline Outro estado & 01 & 1,2 & 04 & 4,8 & 02 & 2,3 & 03 & 3,9 & 10 & 3,0 \\
\hline Total & 87 & 100,0 & 83 & 100,0 & 86 & 100,0 & 77 & 100,0 & 333 & 100,0 \\
\hline
\end{tabular}

A distribuição em relação ao estado civil (Tabela 6) revela que praticamente a metade dos participantes $(49,0 \%)$ situa-se na categoria "amasiado", com a segunda colocação sendo ocupada pelos solteiros (32,7\%). Casados e divorciados/viúvos mostram percentuais semelhantes e bastante inferiores aos grupos anteriormente mencionados (9,0\% e 9,3\%, respectivamente). Comparado aos demais, o pavilhão 1 concentra percentuais mais elevados de indivíduos casados.

A Tabela 7 mostra que a maioria dos pesquisados $(58,3 \%)$ relata já ter realizado exames sorológicos para o HIV, e que quase $1 / 3$ do total refere a realização de tais exames em mais de uma vez $(31,6 \%)$. Percebe-se uma maior concentração de indivíduos já submetidos à sorologia para o HIV dentre aqueles internos no pavilhão 1 , onde os percentuais de realização atingem valores iguais a $33,3 \%$, para um exame, e $39,1 \%$ para exames repetidos. Nos demais pavilhões 
ocorrem valores consideravelmente mais elevados de não realização de testes para o HIV, de modo particular no pavilhão 2 (48,2\%).

Tabela 6 - Distribuição dos presidiários segundo estado civil e pavilhão. Penitenciária de Ribeirão Preto, 2003

\begin{tabular}{|c|c|c|c|c|c|c|c|c|c|c|}
\hline \multirow{3}{*}{$\begin{array}{l}\text { ESTADO } \\
\text { CIVIL }\end{array}$} & \multicolumn{10}{|c|}{ PAVILHÃO } \\
\hline & \multicolumn{2}{|r|}{1} & \multicolumn{2}{|r|}{2} & \multicolumn{2}{|r|}{3} & \multicolumn{2}{|c|}{4} & \multicolumn{2}{|c|}{ Total } \\
\hline & $\mathrm{n}$ & $\%$ & $\mathrm{n}$ & $\%$ & $\mathrm{n}$ & $\%$ & $\mathrm{n}$ & $\%$ & $\mathrm{n}$ & $\%$ \\
\hline Casado & 12 & 13,8 & 07 & 8,4 & 05 & 5,8 & 06 & 7,8 & 30 & 9,0 \\
\hline Solteiro & 19 & 21,8 & 33 & 39,7 & 34 & 39,5 & 23 & 29,9 & 109 & 32,7 \\
\hline $\begin{array}{l}\text { Amasiado } \\
\text { Divorciado - }\end{array}$ & 39 & 44,8 & 40 & 48,3 & 44 & 51,2 & 40 & 51,9 & 163 & 49,0 \\
\hline viúvo & 17 & 19,6 & 03 & 3,6 & 03 & 3,5 & 08 & 10,4 & 31 & 9,3 \\
\hline Total & 87 & 100,0 & 83 & 100,0 & 86 & 100,0 & 77 & 100,0 & 333 & 100,0 \\
\hline
\end{tabular}

Tabela 7 - Distribuição dos presidiários segundo exame anti-HIV prévio e pavilhão. Penitenciária de Ribeirão Preto, 2003.

\section{PAVILHÃO}

EXAME ANTI-

HIV PRÉVIO

\begin{tabular}{lllllllllll} 
& 1 & & 2 & & 3 & & 4 & & Total \\
\hline n & $\%$ & $\mathrm{n}$ & $\%$ & $\mathrm{n}$ & $\%$ & $\mathrm{n}$ & $\%$ & $\mathrm{n}$ & $\%$ \\
\hline
\end{tabular}

$\begin{array}{lllllllllll}\text { Não } & 24 & 27,6 & 40 & 48,2 & 37 & 43,0 & 34 & 44,1 & 135 & 40,5\end{array}$

$\begin{array}{lllllllllll}\text { Uma vez } & 29 & 33,3 & 20 & 24,1 & 21 & 24,4 & 19 & 24,7 & 89 & 26,7\end{array}$

Mais de uma

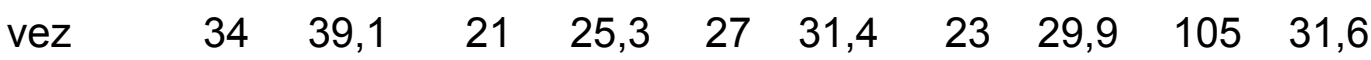

\begin{tabular}{lllllllllll} 
Não sabe & 00 & 0,0 & 02 & 2,4 & 01 & 1,2 & 01 & 1,3 & 04 & 1,2 \\
\hline
\end{tabular}

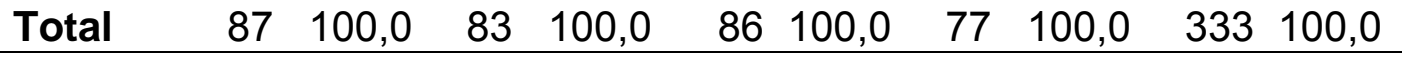


A Tabela 8 mostra a distribuição dos participantes segundo história de consumo de drogas ilícitas não injetáveis, bem como dos tipos de drogas referidas. Percebe-se um amplo consumo dessas drogas na população de estudo, com menos de $1 / 5$ dos participantes negando o seu uso em algum momento da vida $(18,6 \%)$. Como droga de uso isolado destaca-se a maconha, referida por 108 presidiários $(32,4 \%)$. Quando se associa seu uso às outras drogas, seu consumo passa a ser mencionado por mais de 70\% (234/333) do total de participantes. Em relação aos pavilhões, os de número 3 e 4 relatam maiores percentuais de uso de maconha isoladamente ( $37,2 \%$ e $37,6 \%$, respectivamente), quando comparados aos pavilhões 1 e 2. Quando se consideram combinações de drogas, a associação maconha/cocaína é a mais relatada (19,3\%), seguida por maconha/cocaína/crack $(14,7 \%)$. Cocaína, isolada ou combinada, ocupa o segundo lugar na preferência de uso $(38,7 \%$, ou $129 / 333)$, seguida do crack, também isolado ou combinado $(22,2 \%$, 74/333). 
Tabela 8 - Distribuição dos presidiários segundo tipo de droga não injetável usada no passado e pavilhão. Penitenciária de Ribeirão Preto, 2003.

\begin{tabular}{|c|c|c|c|c|c|c|c|c|c|c|}
\hline \multirow{3}{*}{$\begin{array}{c}\text { TIPO DE } \\
\text { DROGA } \\
\text { NÃO } \\
\text { INJETÁVEL }\end{array}$} & \multicolumn{10}{|c|}{ PAVILHÃO } \\
\hline & \multicolumn{2}{|r|}{1} & \multicolumn{2}{|r|}{2} & \multicolumn{2}{|r|}{3} & \multicolumn{2}{|c|}{4} & \multicolumn{2}{|c|}{ Total } \\
\hline & $\mathrm{n}$ & $\%$ & $\mathrm{n}$ & $\%$ & $\mathrm{n}$ & $\%$ & $\mathrm{n}$ & $\%$ & $\mathrm{n}$ & $\%$ \\
\hline Maconha & 27 & 31,1 & 20 & 24,1 & 32 & 37,2 & 29 & 37,6 & 108 & 32,4 \\
\hline Cocaína & 03 & 3,4 & 03 & 3,6 & 02 & 2,3 & 02 & 2,6 & 10 & 3,0 \\
\hline Crack & 02 & 2,3 & 02 & 2,4 & 00 & 0,0 & 02 & 2,6 & 06 & 1,8 \\
\hline $\begin{array}{l}\text { Maconha/ } \\
\text { Cocaína }\end{array}$ & 19 & 21,9 & 14 & 16,9 & 14 & 16,3 & 17 & 22,1 & 64 & 19,3 \\
\hline $\begin{array}{c}\text { Maconha/ } \\
\text { Crack }\end{array}$ & 05 & 5,7 & 03 & 3,6 & 03 & 3,5 & 02 & 2,6 & 13 & 3,9 \\
\hline $\begin{array}{l}\text { Crack/ } \\
\text { Cocaína }\end{array}$ & 02 & 2,3 & 01 & 1,2 & 02 & 2,3 & 01 & 1,3 & 06 & 1,8 \\
\hline $\begin{array}{l}\text { Maconha/ } \\
\text { Crack/ } \\
\text { Cocaína }\end{array}$ & 09 & 10,3 & 14 & 16,9 & 16 & 18,7 & 10 & 13,0 & 49 & 14,7 \\
\hline Outros tipos & 05 & 5,7 & 03 & 3,6 & 02 & 2,3 & 05 & 6,5 & 15 & 4,5 \\
\hline $\begin{array}{c}\text { Nunca } \\
\text { usaram }\end{array}$ & 15 & 17,3 & 23 & 27,7 & 15 & 17,4 & 09 & 11,7 & 62 & 18,6 \\
\hline Total & 87 & 100,0 & 83 & 100,0 & 86 & 100,0 & 77 & 100,0 & 333 & 100,0 \\
\hline
\end{tabular}


O uso de drogas não injetáveis segundo a faixa etária (Tabela 9) revela uma nítida tendência decrescente à medida que aumenta a idade, passando de 88,5\%, entre os mais jovens, a 53,3\% entre aqueles acima de 45 anos ( $\chi^{2}$ para tendência linear $=16,715 ; p<0,0001)$. Destaca-se novamente o enorme consumo de drogas ilícitas não injetáveis nos presidiários estudados, atingindo 81,4\% deles. Agrupandose as faixas etárias "19 a 24" com "25 a 30", e cotejando-as com o agrupamento formado pelas demais, verifica-se associação estatisticamente significante entre as variáveis $\left(\chi^{2}(1 \mathrm{GL})=11,58 ; p=0,001\right)$.

Tabela 9 - Distribuição dos presidiários segundo idade e uso de drogas ilícitas não injetáveis. Penitenciária de Ribeirão Preto, 2003.

\begin{tabular}{|c|c|c|c|c|c|c|}
\hline \multicolumn{7}{|c|}{ DROGAS NÃO INJETÁVEIS } \\
\hline \multirow[t]{2}{*}{ FAIXA ETÁRIA } & \multicolumn{2}{|c|}{ SIM } & \multicolumn{2}{|c|}{$\mathrm{NÃO}$} & \multicolumn{2}{|c|}{ Total } \\
\hline & $\mathrm{n}$ & $\%$ & $\mathrm{n}$ & $\%$ & $\mathrm{n}$ & $\%$ \\
\hline $19-24$ anos & 85 & 88,5 & 11 & 11,5 & 96 & 100,0 \\
\hline $25-30$ anos & 92 & 86,0 & 15 & 14,0 & 107 & 100,0 \\
\hline 31-35 anos & 45 & 81,8 & 10 & 18,2 & 55 & 100,0 \\
\hline 36-45 anos & 41 & 68,3 & 19 & 31,7 & 60 & 100,0 \\
\hline$>45$ anos & 8 & 53,3 & 7 & 46,7 & 15 & 100,0 \\
\hline Total & 271 & 81,4 & 62 & 18,6 & 333 & 100,0 \\
\hline
\end{tabular}

A análise do uso de drogas injetáveis (Tabela 10) mostrou, no geral, sensível diferença quanto ao item anterior. Observa-se baixo consumo deste tipo de droga $(8,7 \%)$, mais concentrada nos participantes de 31 a 35 anos $(21,8 \%)$ e de 36 a 45 anos (10,0\%). Chama atenção a não referência ao uso de drogas injetáveis entre os presos com idade acima de 45 anos. Agrupando-se as faixas etárias até 30 anos e as de 31 ou mais, verifica-se associação entre as variáveis $\left(\chi^{2}{ }_{(1 \mathrm{GL})}=7,07 ; p=\right.$ 0,008). 
Tabela 10 - Distribuição dos presidiários segundo idade e uso de drogas ilícitas injetáveis. Penitenciária de Ribeirão Preto, 2003.

\begin{tabular}{ccccccc}
\hline \multirow{2}{*}{ FAIXA ETÁRIA } & \multicolumn{3}{c}{ DROGAS INJETÁVEIS } \\
\cline { 2 - 7 } & \multicolumn{2}{c}{ SIM } & \multicolumn{2}{c}{ NÃO } & \multicolumn{2}{c}{ Total } \\
\cline { 2 - 7 } & $\mathrm{n}$ & $\%$ & $\mathrm{n}$ & $\%$ & $\mathrm{n}$ & $\%$ \\
\hline 19-24 anos & 04 & 4,2 & 92 & 95,8 & 96 & 100,0 \\
$25-30$ anos & 07 & 6,5 & 100 & 93,5 & 107 & 100,0 \\
$31-35$ anos & 12 & 21,8 & 43 & 78,2 & 55 & 100,0 \\
$36-45$ anos & 06 & 10,0 & 54 & 90,0 & 60 & 100,0 \\
$>45$ anos & 00 & 0,0 & 15 & 100,0 & 15 & 100,0 \\
\hline Total & 29 & 8,7 & 304 & 91,3 & 333 & 100,0 \\
\hline
\end{tabular}

\subsection{Resultados do Estudo de Associação entre Positividade Sorológica ao Hiv e Possíveis Fatores de Risco}

Nas tabelas seguintes serão mostradas apenas aquelas que apresentarem associação entre as covariáveis a positividade ao HIV menor ou igual a 0,25. Dessa forma, as covariáveis que não atingiram este parâmetro, e portanto, não serão tabuladas são as seguintes: estado civil, local de nascimento, local de residência, tempo já cumprido da pena, internação passada em FEBEM, uso de tatuagem, uso de piercing, ocorrência de visita íntima, uso de preservativo em visita íntima, prática sexual entre colegas da prisão, tabagismo.

A Tabela 11 mostra que a presença de sorologia positiva para o anti-HIV ocorre em 19 presos, representando um valor de prevalência total igual a 5,7\% (IC $95 \%$ : 3,2 - 8,2). A distribuição dos portadores do HIV não varia muito dentro dos grupos etários, mostrando-se maior nos presos de 31 a 35 anos $(9,1 \%)$ e nos de 35 a 45 anos (8,3\%). Os indivíduos mais jovens mostram valores de prevalência mais reduzidos, com $4,2 \%$ entre 19 e 24 anos e 3,7\% entre 25 e 30 anos de idade. Entre 
os 15 presidiários acima de 45 anos ocorre apenas um teste positivo, resultando numa prevalência de 6,7\%. Agrupando-se as faixas etárias em duas - até 30 e acima de 30 anos - não se encontra associação estatística com a presença do HIV, ao nível de $5 \%\left(\chi^{2}(1 \mathrm{GL})=3,01 ; p=0,0827\right)$.

Tabela 11 - Distribuição dos presidiários segundo idade e sorologia HIV. Penitenciária de Ribeirão Preto, 2003.

\begin{tabular}{ccccccc}
\hline & \multicolumn{5}{c}{ SOROLOGIA HIV } \\
\cline { 2 - 7 } FAIXA ETÁRIA & \multicolumn{2}{c}{ POSITIVO } & \multicolumn{1}{c}{ NEGATIVO } & \multicolumn{2}{c}{ Total } \\
\cline { 2 - 7 } & $\mathrm{n}$ & $\%$ & $\mathrm{n}$ & $\%$ & $\mathrm{n}$ & $\%$ \\
\hline 19-24 anos & 04 & 4,2 & 92 & 95,8 & 96 & 100,0 \\
25-30 anos & 04 & 3,7 & 103 & 96,3 & 107 & 100,0 \\
$31-35$ anos & 05 & 9,1 & 50 & 90,9 & 55 & 100,0 \\
$36-45$ anos & 05 & 8,3 & 55 & 91,7 & 60 & 100,0 \\
$>45$ anos & 01 & 6,7 & 14 & 93,3 & 15 & 100,0 \\
\hline Total & 19 & 5,7 & 314 & 94,3 & 333 & 100,0 \\
\hline
\end{tabular}

A distribuição dos participantes segundo o pavilhão (Tabela 12) mostra que o número 2 reúne a maior quantidade de soropositivos $(8,4 \%)$, seguidos do $1(5,8 \%)$ e do 3 com (4,7\%). O pavilhão 4, que tem a menor participação numérica, é também aquele com o mais baixo valor de prevalência $(3,9 \%)$. A análise estatística não mostra associação entre as variáveis $\left(\chi^{2}{ }_{(3 \mathrm{GL})}=1,79 ; \mathrm{p}=0,616\right)$. 
Tabela 12 - Distribuição dos presidiários segundo pavilhão e sorologia HIV. Penitenciária de Ribeirão Preto, 2003.

\begin{tabular}{ccccccc}
\hline & \multicolumn{7}{c}{ SOROLOGIA HIV } \\
\cline { 2 - 7 } PAVILHÃO & \multicolumn{2}{c}{ POSITIVO } & \multicolumn{2}{c}{ NEGATIVO } & \multicolumn{2}{c}{ Total } \\
\cline { 2 - 8 } & $\mathrm{n}$ & $\%$ & $\mathrm{n}$ & $\%$ & $\mathrm{n}$ & $\%$ \\
\hline 1 & 5 & 5,8 & 82 & 94,2 & 87 & 100,0 \\
2 & 7 & 8,4 & 76 & 91,6 & 83 & 100,0 \\
3 & 4 & 4,7 & 82 & 95,3 & 86 & 100,0 \\
4 & 3 & 3,9 & 74 & 96,1 & 77 & 100,0 \\
\hline Total & 19 & 5,7 & 314 & 94,3 & 333 & 100,0 \\
\hline
\end{tabular}

A Tabela 13 revela que os extremos do tempo de escolaridade têm distribuições inversamente proporcionais à positividade sorológica ao HIV, variando de $0 \%$, nos mais escolarizados, a $7,8 \%$ naqueles com menos tempo na escola. Em seguida ao primeiro colocado vem o grupo de 5 a 8 anos, com $7,4 \%$ de positividade. O grupo de 2 a 5 anos tem uma prevalência de 5,4\% e reúne 42,1\% (8/19) dos 19 positivos detectados. No geral, destaca-se o reduzido nível de escolaridade da população de estudo, com a maioria situando-se entre 2 e 5 anos de freqüência à escola (147/333, ou 44,1\%). Agrupando-se as categorias de escolaridade até 8 anos e acima desta faixa, a análise estatística não evidencia diferenças significativas (teste exato de Fisher: $p=0,145$ ).

Tabela 13 - Distribuição dos presidiários segundo escolaridade e sorologia HIV. Penitenciária de Ribeirão Preto, 2003.

\begin{tabular}{crrrrrrc}
\hline & \multicolumn{7}{c}{ SOROLOGIA HIV } \\
\cline { 2 - 7 } ESCOLARIDADE & \multicolumn{2}{c}{ POSITIVO } & \multicolumn{2}{c}{ NEGATIVO } & \multicolumn{2}{c}{ Total } \\
\cline { 2 - 8 } & $\mathrm{n}$ & $\%$ & $\mathrm{n}$ & $\%$ & $\mathrm{n}$ & $\%$ \\
\hline Até 2 anos & 4 & 7,8 & 47 & 92,2 & 51 & 100,0 \\
2 a 5 anos & 8 & 5,4 & 139 & 94,6 & 147 & 100,0 \\
5 a 8 anos & 7 & 7,4 & 88 & 92,6 & 95 & 100,0 \\
Colegial e acima & 0 & 0,0 & 40 & 100,0 & 40 & 100,0 \\
\hline Total & 19 & 5,7 & 314 & 94,3 & 333 & 100,0 \\
\hline
\end{tabular}


A distribuição segundo tempo da pena total é mostrada na Tabela 14. Percebe-se que a positividade ao HIV mostra-se inversamente proporcional ao tempo de pena, com $11,8 \%$ naqueles com até 5 anos e 3,3\% entre os condenados a mais de 5 anos. A análise estatística mostra associação entre as variáveis $\left(\chi^{2}{ }_{(1 \mathrm{GL})}=\right.$ 8,98; $p=0,003)$.

Tabela 14 - Distribuição dos presidiários segundo tempo da pena total e sorologia HIV. Penitenciária de Ribeirão Preto, 2003.

\begin{tabular}{ccccccc} 
TEMPO DA PENA & \multicolumn{7}{c}{ SOROLOGIA HIV } \\
\cline { 2 - 8 } TOTAL & \multicolumn{2}{c}{ POSITIVO } & \multicolumn{2}{c}{ NEGATIVO } & \multicolumn{2}{c}{ Total } \\
\cline { 2 - 8 } & $\mathrm{n}$ & $\%$ & $\mathrm{n}$ & $\%$ & $\mathrm{n}$ & $\%$ \\
\hline Até 5 anos & 11 & 11,8 & 82 & 88,2 & 93 & 100,0 \\
Acima de 5 anos & 08 & 3,3 & 232 & 96,7 & 240 & 100,0 \\
\hline Total & 19 & 5,7 & 314 & 94,3 & 333 & 100,0 \\
\hline
\end{tabular}

Conforme mostrado na Tabela 15, a positividade ao HIV alcança $7,7 \%$ entre os 194 indivíduos com antecedentes de realização de exames prévios para este vírus, contra $2,9 \%$ entre os que nunca o realizaram. A análise estatística mostra um valor de probabilidade borderline $\left(\chi_{(1 \mathrm{GL})}^{2}=3,54 ; p=0,060\right)$.

Tabela 15 - Distribuição dos presidiários segundo ter realizado exame anti-HIV prévio e sorologia HIV. Penitenciária de Ribeirão Preto, 2003.

\begin{tabular}{ccccccc}
\hline & \multicolumn{7}{c}{ SOROLOGIA HIV } \\
EXAME anti- \\
\cline { 2 - 7 } HIV PRÉVIO & \multicolumn{2}{c}{ POSITIVO } & NEGATIVO & \multicolumn{2}{c}{ Total } \\
\cline { 2 - 7 } & $\mathrm{n}$ & $\%$ & $\mathrm{n}$ & $\%$ & $\mathrm{n}$ & $\%$ \\
\hline Sim & 15 & 7,7 & 179 & 87,5 & 194 & 100,0 \\
Não & 04 & 2,9 & 135 & 97,1 & 139 & 100,0 \\
\hline Total & 19 & 5,7 & 314 & 94,3 & 333 & 100,0 \\
\hline
\end{tabular}


Antecedente de DST não ulcerativa é referido por 30,6\% dos participantes (102/333), entre os quais a positividade ao HIV alcança 9,8\% (Tabela 16). Entre os que não apresentam antecedentes de tais doenças, a prevalência atinge $3,9 \%$. A análise estatística mostra associação entre as variáveis $\left(\chi^{2}(1 \mathrm{GL})=4,59 ; p=0,032\right)$.

Conforme pode ser visto na Tabela 17, antecedentes de DSTs ulcerativas são relatados por apenas $7,2 \%$ dos participantes (24/333). Nesses, a prevalência de HIV atinge $8,3 \%$, contra um valor de $5,5 \%$ entre os que não referem tais antecedentes. $A$ análise estatística não mostra associação entre as variáveis (teste exato de Fisher: $p$ $=0,637)$.

Tabela 16 - Distribuição dos presidiários segundo DST prévia não ulcerativa e sorologia HIV. Penitenciária de Ribeirão Preto, 2003.

\begin{tabular}{ccccccc} 
& \multicolumn{9}{c}{ SOROLOGIA HIV } \\
\cline { 2 - 7 } $\begin{array}{c}\text { DST PRÉVIA } \\
\text { NÃO } \\
\text { ULCERATIVA }\end{array}$ & \multicolumn{2}{c}{ POSITIVO } & \multicolumn{2}{c}{ NEGATIVO } & \multicolumn{2}{c}{ Total } \\
\cline { 2 - 7 } & $\mathrm{n}$ & $\%$ & $\mathrm{n}$ & $\%$ & $\mathrm{n}$ & $\%$ \\
\hline Sim & 10 & 9,8 & 92 & 90,2 & 102 & 100,0 \\
Não & 09 & 3,9 & 222 & 96,1 & 231 & 100,0 \\
\hline Total & 19 & 5,7 & 314 & 94,3 & 333 & 100,0 \\
\hline
\end{tabular}

Tabela 17 - Distribuição dos presidiários segundo DST prévia ulcerativa e sorologia HIV. Penitenciária de Ribeirão Preto, 2003.

\begin{tabular}{|c|c|c|c|c|c|c|}
\hline \multirow{3}{*}{$\begin{array}{l}\text { DST PRÉVIA } \\
\text { ULCERATIVA }\end{array}$} & \multicolumn{6}{|c|}{ SOROLOGIA HIV } \\
\hline & \multicolumn{2}{|c|}{ POSITIVO } & \multicolumn{2}{|c|}{ NEGATIVO } & \multicolumn{2}{|c|}{ Total } \\
\hline & $\mathrm{n}$ & $\%$ & $\mathrm{n}$ & $\%$ & $\mathrm{n}$ & $\%$ \\
\hline Sim & 02 & 8,3 & 22 & 91,7 & 24 & 100,0 \\
\hline Não & 17 & 5,5 & 292 & 94,5 & 309 & 100,0 \\
\hline Total & 19 & 5,7 & 314 & 94,3 & 333 & 100,0 \\
\hline
\end{tabular}


$\mathrm{Na}$ Tabela 18 chama a atenção que apenas um dentre todos os participantes relata preferência homossexual (0,3\%). Este indivíduo tem sorologia positiva para o HIV e, apesar de único, sua positividade faz com que se chegue muito próximo ao limite adotado de significância estatística (teste exato de Fisher: $p=0,057$ ).

Tabela 18 - Distribuição dos presidiários segundo preferência sexual e sorologia HIV. Penitenciária de Ribeirão Preto, 2003.

\begin{tabular}{|c|c|c|c|c|c|c|}
\hline \multirow{3}{*}{$\begin{array}{l}\text { PREFERÊNCIA } \\
\text { SEXUAL }\end{array}$} & \multicolumn{6}{|c|}{ SOROLOGIA HIV } \\
\hline & \multicolumn{2}{|c|}{ POSITIVO } & \multicolumn{2}{|c|}{ NEGATIVO } & \multicolumn{2}{|c|}{ Total } \\
\hline & $\mathrm{n}$ & $\%$ & $\mathrm{n}$ & $\%$ & $\mathrm{n}$ & $\%$ \\
\hline Heterossexual & 18 & 5,4 & 314 & 94,2 & 332 & 100,0 \\
\hline Homossexual & 1 & 100,0 & 00 & 0,0 & 1 & 100,0 \\
\hline Total & 19 & 5,7 & 82 & 95,3 & 333 & 100,0 \\
\hline
\end{tabular}

Como mostra a Tabela 19, em 14 participantes (4,2\%) há história de contatos sexuais com mais de 10 diferentes parceiras, no ano que antecedeu 0 encarceramento. A prevalência de HIV neste grupo (14,3\%) não mostra diferença estatisticamente significativa em relação ao valor apresentado pelos que relatam contatos sexuais com até 10 parceiras $(5,3 \%)$ no mesmo período (teste exato de Fisher: $p=0,188)$.

Tabela 19 - Distribuição dos presidiários segundo número de parceiras um ano antes da prisão e sorologia HIV. Penitenciária de Ribeirão Preto, 2003.

\begin{tabular}{crrrrrr} 
N ${ }^{\circ}$ PARCEIRAS & \multicolumn{5}{c}{ SOROLOGIA HIV } \\
\cline { 2 - 8 } UM ANO ANTES & \multicolumn{2}{c}{ POSITIVO } & \multicolumn{2}{c}{ NEGATIVO } & \multicolumn{2}{c}{ Total } \\
\cline { 2 - 8 } DA PRISÃO & \multicolumn{1}{c}{$\mathrm{n}$} & $\%$ & $\mathrm{n}$ & $\%$ & $\mathrm{n}$ & $\%$ \\
\hline Até 10 parceiras & 17 & 5,4 & 300 & 94,6 & 317 & 100,0 \\
$>10$ parceiras & 2 & 14,3 & 12 & 85,7 & 14 & 100,0 \\
\hline Total & 19 & 5,7 & 312 & 94,3 & $331^{*}$ & 100,0 \\
\hline
\end{tabular}

* Neste item, 2 participantes não deram resposta 
A condição de circuncidado (Tabela 20) é manifestada por $7,8 \%$ dos sentenciados (26/333). A positividade ao HIV neste grupo (11,5\%) revela-se mais elevada do que entre os que não foram submetidos à circuncisão $(5,2 \%)$, porém esta diferença não é estatisticamente significativa (teste exato de Fisher: $p=0,177$ ).

Tabela 20 - Distribuição dos presidiários segundo circuncisão e sorologia HIV. Penitenciária de Ribeirão Preto, 2003.

\begin{tabular}{ccccccc} 
& \multicolumn{9}{c}{ SOROLOGIA HIV } \\
\cline { 2 - 7 } CIRCUNCIDADO & \multicolumn{1}{c}{ POSITIVO } & NEGATIVO & \multicolumn{2}{c}{ Total } \\
\cline { 2 - 7 } & $\mathrm{n}$ & $\%$ & $\mathrm{n}$ & $\%$ & $\mathrm{n}$ & $\%$ \\
\hline Sim & 03 & 11,5 & 23 & 88,4 & 26 & 100,0 \\
Não & 16 & 5,2 & 291 & 94,8 & 307 & 100,0 \\
\hline Total & 19 & 5,7 & 314 & 94,3 & 333 & 100,0 \\
\hline
\end{tabular}

Conforme mostrado na Tabela 21 , um percentual de $45,6 \%$ dos participantes (152/333) revela história de relacionamento sexual com parceira usuária de drogas ilícitas. A positividade ao marcador ocorre em $8,5 \%$ daqueles com este antecedente, contra $3,3 \%$ dos que o negam. O resultado do teste estatístico demonstra associação entre as variáveis $\left(\chi^{2}{ }_{(1 \mathrm{GL})}=4,21 ; p=0,04\right)$.

A tabela 22 mostra uma positividade ao HIV muito mais elevada entre os 29 indivíduos com história de uso de drogas ilícitas injetáveis, quando comparada com o valor apresentado pelos que nunca as utilizaram (34,5\% e 3,0\%, respectivamente). A análise estatística revela forte associação entre as variáveis (teste exato de Fisher: $p=0,000)$. 
Tabela 21 - Distribuição dos presidiários segundo já ter tido relações sexuais com usuária de drogas ilícitas e sorologia HIV. Penitenciária de Ribeirão Preto, 2003.

\begin{tabular}{|c|c|c|c|c|c|c|}
\hline \multirow{3}{*}{$\begin{array}{l}\text { SEXO COM } \\
\text { USUÁRIA } \\
\text { DE DROGAS } \\
\text { ILÍCITAS }\end{array}$} & \multicolumn{6}{|c|}{ SOROLOGIA HIV } \\
\hline & \multicolumn{2}{|c|}{ POSITIVO } & \multicolumn{2}{|c|}{ NEGATIVO } & \multicolumn{2}{|c|}{ Total } \\
\hline & $\mathrm{n}$ & $\%$ & $\mathrm{n}$ & $\%$ & $\mathrm{n}$ & $\%$ \\
\hline Sim & 13 & 8,5 & 139 & 91,5 & 152 & 100,0 \\
\hline Não & 06 & 3,3 & 175 & 96,7 & 181 & 100,0 \\
\hline Total & 19 & 5,7 & 314 & 94,3 & 333 & 100,0 \\
\hline
\end{tabular}

Tabela 22 - Distribuição dos presidiários segundo uso de drogas ilícitas injetáveis no passado e sorologia HIV. Penitenciária de Ribeirão Preto, 2003.

\begin{tabular}{ccccccc}
\hline & \multicolumn{9}{c}{ SOROLOGIA HIV } \\
\cline { 2 - 7 } $\begin{array}{c}\text { PASSADO } \\
\text { DE } \\
\text { DROGAS } \\
\text { INJETÁVEIS }\end{array}$ & $\mathrm{n}$ & $\%$ & POSITIVO & NEGATIVO & \multicolumn{2}{c}{ Total } \\
\cline { 2 - 7 } Sim & 10 & 34,5 & 19 & 65,5 & 29 & 100,0 \\
Não & 09 & 3,0 & 295 & 97,0 & 304 & 100,0 \\
\hline Total & 19 & 5,7 & 314 & 94,3 & 333 & 100,0 \\
\hline
\end{tabular}


Como visto na tabela 23 , um pequeno número de participantes (11, ou 3,3\%) relata história de compartilhamento de agulhas em algum momento da vida. Todavia, a positividade ao HIV entre eles $(63,6 \%)$ mostra-se muito mais elevada do que entre os que não apresentam este antecedente (3,7\%). A análise estatística mostra forte associação entre as variáveis (teste exato de Fisher: $p=0,000$ ).

Tabela 23 - Distribuição dos presidiários segundo compartilhamento de agulha no passado e sorologia HIV. Penitenciária de Ribeirão Preto, 2003.

\begin{tabular}{ccccccc}
\hline $\begin{array}{c}\text { COMPARTILHA- } \\
\text { MENTO DE }\end{array}$ & \multicolumn{7}{c}{ SOROLOGIA HIV } \\
AGULHA NO & \multicolumn{1}{c}{ POSITIVO } & NEGATIVO & \multicolumn{2}{c}{ Total } \\
\cline { 2 - 7 } PASSADO & $\mathrm{n}$ & $\%$ & $\mathrm{n}$ & $\%$ & $\mathrm{n}$ & $\%$ \\
\hline Sim & 07 & 63,6 & 04 & 36,4 & 11 & 100,0 \\
Não & 12 & 3,7 & 310 & 96,3 & 322 & 100,0 \\
\hline Total & 19 & 5,7 & 314 & 94,3 & 333 & 100,0 \\
\hline
\end{tabular}

Antecedentes de transfusão sanguínea (Tabela 24) são referidos por 9,6\% (32/333) dos participantes. Embora a positividade ao HIV neste grupo mostre um valor (12,5\%) mais elevado do que entre aqueles que não apresentam história desta exposição (5,0\%), a análise estatística não revela associação entre as variáveis, ao nível de 5\% (teste exato de Fisher: $p=0,097$ ).

Tabela 24 - Distribuição dos presidiários segundo transfusão sanguinea no passado e sorologia HIV. Penitenciária de Ribeirão Preto, 2003.

TRANSFUSÃO

SOROLOGIA HIV

SANGUINEA

POSITIVO NEGATIVO

Total

\begin{tabular}{ccccccc} 
& $\mathrm{n}$ & $\%$ & $\mathrm{n}$ & $\%$ & $\mathrm{n}$ & $\%$ \\
\hline Sim & 04 & 12,5 & 28 & 87,5 & 32 & 100,0 \\
Não & 15 & 5,0 & 286 & 95,0 & 301 & 100,0 \\
\hline Total & 19 & 5,7 & 314 & 94,3 & 333 & 100,0 \\
\hline
\end{tabular}


História prévia de hepatite (Tabela 25) é relatada por $8,1 \%$ dos participantes (27/333), e entre eles a positividade ao HIV mostra-se mais elevada do que no grupo sem este antecedente (14,8\% e 4,9\%, respectivamente). A análise estatística revela um valor de "p" no limite da significância (teste exato de Fisher: $p=0,057$ ).

Tabela 25 - Distribuição dos presidiários segundo passado de hepatite e sorologia HIV. Penitenciária de Ribeirão Preto, 2003.

\begin{tabular}{ccccccc}
\hline & \multicolumn{7}{c}{ SOROLOGIA HIV } \\
\cline { 2 - 7 } $\begin{array}{c}\text { ANTECEDENTE } \\
\text { DE HEPATITE }\end{array}$ & \multicolumn{2}{c}{ POSITIVO } & \multicolumn{1}{c}{ NEGATIVO } & \multicolumn{2}{c}{ Total } \\
\cline { 2 - 7 } & $\mathrm{n}$ & $\%$ & $\mathrm{n}$ & $\%$ & $\mathrm{n}$ & $\%$ \\
\hline Sim & 04 & 14,8 & 23 & 85,2 & 27 & 100,0 \\
Não & 15 & 4,9 & 291 & 95,1 & 306 & 100,0 \\
\hline Total & 19 & 5,7 & 314 & 94,3 & 333 & 100,0 \\
\hline
\end{tabular}

Em relação ao passado de icterícia (Tabela 26), 7,2\% dos participantes relatam tal antecedente (24/333). Neles, a positividade ao HIV alcança 16,7\%, valor mais elevado do que o observado no grupo que não refere história de icterícia $(4,9 \%)$. A análise estatística mostra associação entre as variáveis (teste exato de Fisher: $p=0,039$ ).

Tabela 26 - Distribuição dos presidiários segundo antecedente de icterícia e sorologia do HIV. Penitenciária de Ribeirão Preto, 2003.

\begin{tabular}{ccccccc}
\hline & \multicolumn{7}{c}{ SOROLOGIA HIV } \\
\cline { 2 - 7 } $\begin{array}{c}\text { ANTECEDENTE } \\
\text { ICTERÍCIA }\end{array}$ & \multicolumn{2}{c}{ POSITIVO } & \multicolumn{2}{c}{ NEGATIVO } & \multicolumn{2}{c}{ Total } \\
\cline { 2 - 7 } & $\mathrm{n}$ & $\%$ & $\mathrm{n}$ & $\%$ & $\mathrm{n}$ & $\%$ \\
\hline Sim & 04 & 16,7 & 20 & 83,3 & 24 & 100,0 \\
Não & 15 & 4,9 & 294 & 95,1 & 309 & 100,0 \\
\hline \multirow{2}{*}{ Total } & 19 & 5,7 & 314 & 94,3 & 333 & 100,0 \\
\hline
\end{tabular}




\subsection{Análise Multivariada}

Todas as variáveis que na análise univariada anteriormente descrita mostraram um valor de "p" igual ou menor que 0,25 foram selecionadas para análise multivariada, mediante a aplicação de um modelo de regressão logística, onde a variável resposta é a presença ou não da infecção do HIV e as co-variáveis estão aqui listadas com seus códigos correspondentes:

\section{Idade}

$$
1=31 \text { a } 69 \text { anos; } 0 \text { = Até } 30 \text { anos }
$$

\section{Escolaridade}

1 = Até 8 anos; 0 = Acima de 8 anos

\section{Pena total}

1 = Até 5 anos; 0 = Acima de 5 anos

\section{Anti-HIV prévio}

$$
1=\operatorname{sim} ; 0 \text { = não }
$$

\section{DSTs não ulcerativas}

$$
1=\operatorname{sim} ; 0 \text { = não }
$$

\section{Preferência sexual}

$$
1 \text { = homossexual; } 0 \text { = heterossexual }
$$

\section{Parceiras um ano antes da prisão}

$$
1 \text { = Acima de } 10 \text { parceiras; } 0 \text { = Até } 10 \text { parceiras }
$$

\section{Circuncidado}

$$
1=\operatorname{sim} ; 0 \text { = não }
$$

9 Relação sexual com usuário de drogas ilícitas

$$
1=\operatorname{sim} ; 0 \text { = não }
$$

10 Uso de drogas ilícitas injetáveis no passado

$$
1=\operatorname{sim} ; 0 \text { = não }
$$

11 Compartilhamento de agulha no passado

$$
1=\operatorname{sim} ; 0 \text { = não }
$$

\section{Transfusão sanguinea}

$$
1=\operatorname{sim} ; 0 \text { = não }
$$

13 Antecedentes de hepatite

$$
1=\operatorname{sim} ; 0 \text { = não }
$$

14 Antecedentes de icterícia

$$
1 \text { = sim; } 0 \text { = não }
$$


$\mathrm{Na}$ Tabela 27, apresentamos os resultados obtidos sob o enfoque Baysiano $^{202}$, onde utilizamos métodos computacionais recentes, de simulação para obter as amostras da distribuição a posteriori de interesse (amostrador de Gibbs). Além disso, utilizamos densidades a priori não informativas para parâmetros do modelo.

Tabela 27 - Média a posteriori e intervalos de credibilidade para os coeficientes do modelo de regressão logística.

\begin{tabular}{l|lc}
\hline Variável & Média & $\begin{array}{c}\text { Intervalo de } \\
\text { credibilidade 95\% }\end{array}$ \\
\hline idade & $-0,599$ & $(-0,13 ; 0,005)$ \\
DST não ulcerativa & 0,653 & $(-0,61 ; 1,96)$ \\
circuncisão & 1,583 & $(-0,16 ; 3,16)^{*}$ \\
preferência sexual & 8,44 & $(-0,73 ; 22,21)^{*}$ \\
antecedente icterícia & 0,261 & $(-2,08 ; 2,72)$ \\
antecedente hepatite & $-0,327$ & $(-2,56 ; 1,76)$ \\
passado droga injetável & 1,568 & $(-0,31 ; 3,23)^{*}$ \\
escolaridade & 0,930 & $(-0,78 ; 3,04)$ \\
transfusão sanguínea & 0,363 & $(-1,58 ; 2,03)$ \\
exame anti-HIV prévio & 0,297 & $(-0,98 ; 1,61)$ \\
sexo usuário de drogas & 0,007 & $(-1,19 ; 1,17)$ \\
passado compartilhamento de agulhas & 2,670 & $(0,55 ; 5,00)^{\star *}$ \\
$n^{\circ}$ parceira 01 antes da prisão & $-0,352$ & $(-3,41 ; 1,97)$ \\
tempo da pena total & 1,297 & $(0,10 ; 2,48)^{\star *}$ \\
\hline
\end{tabular}

**significativo ao nível de 5\%

* significativo ao nível de 10\% 


\section{DISCUSSÃO}

\subsection{Considerações Gerais}

A materialização de um plano de pesquisa se conduz por uma série de passos, que inclui a escolha do objeto de estudo, elaboração do projeto, permissão para desenvolvê-lo, suporte logístico e financeiro, realização do trabalho de campo, análise dos dados e redação final do texto.

A idéia inicial da pesquisa era estudar algum grupo de indivíduos com risco elevado para aquisição de DSTs, como prostitutas, meninos de rua, presidiários, caminhoneiros, etc. Tais grupos já apresentam programas específicos de prevenção, junto à Coordenação Nacional de DST/AIDS, com relativo sucesso. A opção pelos presidiários se fez pela grande relevância do problema entre eles e pelo fato de constituírem uma população confinada, com acesso potencialmente mais fácil. Além disso, os estudos similares no Estado de São Paulo já datam de pelo menos sete anos, o que estimulava a realização de uma nova pesquisa que pudesse fornecer um instantâneo atual da infecção pelo HIV na população encarcerada. Adicionalmente, a idéia contava com o apoio do Programa de DST/AIDS da Secretaria Municipal de Saúde de Ribeirão Preto, que se dispôs a financiar a realização do teste sorológico para o HIV. Este Programa mantém trabalhos de assistência e prevenção nas três unidades prisionais de Ribeirão Preto, o que facilitou o contato com uma delas, a Penitenciária de Ribeirão Preto. Inaugurada há três anos, esta instituição ainda não tinha sido objeto de estudo semelhante.

O projeto de pesquisa foi prontamente aceito pela divisão médica da Penitenciária, facilitando o aval por parte da sua diretoria. Apesar disso, o primeiro e mais importante impasse aconteceu neste momento. Não obstante a aquiescência da direção, havia a necessidade da concordância formal de órgãos superiores do Governo do Estado para a execução do projeto. A solicitação da permissão para a realização do trabalho foi entregue em meados de outubro de 2002, mas o consentimento se formalizou apenas no início de 2003. Esta espera de quase sete meses foi bastante angustiante, uma vez que sem a autorização das autoridades 
estaduais o projeto não poderia ter a sua aprovação final pelo Comitê de Ética em Pesquisa do Hospital das Clínicas de Ribeirão Preto.

\subsubsection{Divulgação da pesquisa entre os presidiários}

Existem comitês educacionais, comandados por professores da rede de ensino pública, que desenvolvem atividades de ensino e cultura junto aos presos. Estes educadores, por estarem em contato diário com boa parte dos encarcerados, foram o ponto inicial da divulgação da pesquisa. Todavia, logo no início dos procedimentos de campo percebeu-se que praticamente nenhum dos primeiros entrevistados tinha conhecimento adequado da natureza da investigação, o que exigiu que se pensasse na execução de algum trabalho prévio que viesse a sanar esta lacuna.

Os auxiliares de enfermagem do serviço lançaram a idéia de conversar com os assim chamados "enfermeiros" de cada um dos quatro pavilhões, representados por presos que tem um conhecimento básico da área da saúde e exercem ascendência perante os demais. Na verdade, estes indivíduos têm um papel de elo de ligação entre os colegas e a enfermaria, repassando as necessidades relacionadas à saúde do grupo, tais como: presença de medicações básicas, melhor assistência médica e odontológica, atenção aos presos mais debilitados, etc. Costumam, ainda, encaminhar pequenos rascunhos com manuscritos individuais (conhecidos como "pipa") de solicitação de algum tipo de atendimento ou realização de um determinado exame.

A participação dos "enfermeiros" levou a que boa parte dos presos já demonstrasse conhecimento sobre a natureza da pesquisa, ao chegar ao primeiro contato com a equipe. Mesmo assim, alguns desistiram de participar após tomarem ciência plena através das informações contidas no termo de consentimento.

\subsubsection{Inclusão dos participantes}

Como descrito na metodologia, a participação se deu por intermédio de um sorteio que envolveu 100 presos de cada um dos quatro pavilhões. Os nomes dos sorteados eram passados ao agente penitenciário plantonista responsável pela enfermaria, que os repassava aos seus colegas de plantão naquele determinado pavilhão. Os participantes vinham em grupos de três a quatro e, enquanto um era contatado, os outros aguardavam em uma pequena cela ao fundo da enfermaria. 
Cada pessoa era abordada individualmente pelo pesquisador, que expunha todo o trabalho através de leitura das informações do termo de consentimento e complementava, se necessário, dirimindo dúvidas que surgissem. As informações constavam basicamente de explicações sobre formas de contaminação, sinais de manifestação clínica das doenças em estudo (sífilis, infecção pelo HIV, hepatites B e C) e finalizava com a proposta de colher sangue para realização destas sorologias e responder a um questionário com dados pessoais.

Os sentenciados sorteados que não compareceram ao chamado ou compareceram, mas não se dispuseram a participar, foram repostos por outros em novo sorteio, sempre com o objetivo de alcançar 100 presidiários por pavilhão.

Percebeu-se que a grande motivação da adesão à pesquisa foi o oferecimento do teste sorológico para o HIV, embora este exame seja oferecido de rotina a todo preso, ao adentrar a penitenciária. Mesmo já no cumprimento da pena, o teste pode ser realizado por qualquer um que venha a solicitá-lo aos funcionários da divisão médica. Entretanto, ficou claro que mais importante do que disponibilizar a sorologia era a garantia do retorno do resultado em mãos, tendo alguns manifestado a queixa de que resultados de exames anteriores, realizados nesta ou em outras penitenciárias, não foram jamais retornados nem oralmente, muito menos devolvidos através de um documento que pudesse ser mantido em seu poder.

Ao mesmo tempo que funcionava como estímulo para a maioria, a realização do anti-HIV surgia como uma barreira à participação de outros. Assim como descrito por Behrendt et al. ${ }^{113}$, alguns demonstraram receio de se submeter ao exame ou acreditavam não estar sob qualquer risco de contaminação. Outros evidenciaram um enorme pavor, recusando terminantemente realizar a sorologia. Dois chegaram a comentar sobre as conseqüências desastrosas de tomar conhecimento de um eventual resultado positivo nas condições de vida que levavam.

\subsubsection{Acesso e contato com os presidiários}

Quem nunca se expôs a um ambiente de presídio e nele nunca desempenhou qualquer trabalho, não tem condições de avaliar todas as peculiaridades de tal meio e as dificuldades que se colocam à execução das tarefas de uma investigação científica. Inicialmente, há o temor instintivo pelas condições de segurança pessoal, bastante presente nos primeiros dias e que foi se diluindo à medida que o tempo passava e que se percebia uma boa aceitação do trabalho por parte dos reclusos. 
De qualquer maneira, não se pode perder de vista que sempre existe um certo componente de risco, o que torna necessário uma estrita observância das orientações fornecidas pelos funcionários.

Para se alcançar a enfermaria, local onde foram executados os procedimentos da investigação, há necessidade de se passar por oito portões e dois detectores de metais. Além da distância, o tempo gasto podia ser aumentado se houvesse alguma viatura chegando ou algum caminhão descarregando materiais, uma vez que todos os indivíduos e veículos necessitam revista individual.

A prática de campo contrariou a idéia inicial de que o acesso aos participantes seria facilitado, por tratar-se de população confinada. Pelo contrário, inúmeros entraves acabaram por dificultar este acesso. Entre eles, a disponibilidade nem sempre constante de escolta para acompanhar o pesquisador, a necessidade da presença contínua de um agente penitenciário na enfermaria e, de modo especial, a dependência da disposição dos agentes dos pavilhões para arrebanhar os escolhidos do dia. Situações eventuais também contribuíram para inviabilizar o acesso em alguns momentos, tais como o dia em que ocorreu uma revista geral em todas as celas e uma tarde de quinta feira que coincidiu com o televisionamento de uma partida da seleção brasileira de futebol, fazendo com que nenhum dos sorteados do dia comparecesse à enfermaria.

De maneira geral, todavia, o contato com os presidiários se produziu de forma extremamente tranqüila, sem haver, em nenhum momento, qualquer tipo de estresse ou apreensão. Com raríssimas exceções, todos foram educados e se portaram de modo muito respeitoso. Caminhavam sempre com mãos para trás e cabeça abaixada, e eram orientados a somente a se pronunciar se fossem inquiridos. Em determinados momentos se notava que alguns presos demonstravam receio de negar a participação, acreditando na possibilidade de advir alguma forma de prejuízo à sua pessoa. Este fato tende a ocorrer sempre que se trabalha com populações que se sintam com algum grau de dependência em relação à instituição executora da pesquisa ou ao investigador, exigindo da parte desse um investimento adicional de tempo no sentido de garantir ao indivíduo o seu absoluto direito de recusa, sem qualquer ameaça de represália.

Os participantes apresentaram boa compreensão e aceitação do que foi proposto como objetivo da investigação. Claro que não se acredita que a participação ocorreu exclusivamente por reconhecimento da relevância de um 
estudo soroepidemiológico em uma população de risco. Muitos aproveitaram a oportunidade para pleitear um atendimento médico junto ao pesquisador ou reclamar de alguma carência que os afligissem. Outros solicitaram, a título de auxílio, um empenho para conseguir uma medicação, um atendimento especializado ou, até mesmo, melhor colchão para dormir. O pesquisador ajudou na medida do possível, inclusive fazendo atendimento de casos que surgiam quando não havia médico disponível, em situações como emergência hipertensiva, traumas leves, pequenos cortes e avaliação de ferida infectada. Numa ocasião, assinou até solicitação de exames para uma dupla de agentes carcerários.

Durante a entrevista, os encarcerados demonstraram um surpreendente grau de conhecimento das formas de transmissão de DSTs e, sobretudo, do HIV. Isso deve ser reflexo de atividades educacionais implementadas pela penitenciária, que são realizadas de forma periódica e em conjunto com o Programa de DST/AIDS de Ribeirão Preto. Por outro lado, essa percepção do risco de contaminação não se traduziu no uso constante de preservativo em visita íntima, referida por apenas $20,7 \%$ deles. Outro ponto contraditório, avaliado aqui de forma subjetiva, foi a recusa em se submeter ao exame anti-HIV porque a companheira já o realizara previamente em alguma gestação, com resultado não reagente. Estes desistentes utilizaram raciocínio formal para justificar a não adesão: "se a pessoa com quem mantenho relação sexual não tem nada, eu também não tenho".

\subsubsection{Considerações sobre a aplicação do questionário}

Por conter perguntas íntimas que são essenciais na investigação de fatores de risco para DSTs e hepatites virais, já se esperava que a aplicação do questionário pudesse gerar dificuldades. Em condições ideais, a entrevista deveria se fazer em ambiente de total privacidade e com a garantia de absoluto sigilo. Infelizmente, tais condições nem sempre são alcançadas em um estudo com essas características onde o espaço é dividido com funcionários da Instituição -, forçando, algumas vezes, a interrupção da entrevista pela entrada de terceiros à sala.

Assim, é de se esperar algumas limitações no que diz respeito à confiabilidade de algumas questões. Contribuem para isso não só as dificuldades relacionadas ao ambiente de trabalho, mas também o estigma social que acompanha algumas práticas comportamentais. Intuitivamente, contudo, considerase que a confiabilidade geral das informações trabalhadas seja de um nível 
aceitável, em decorrência de todos os esforços empregados no sentido de se maximizá-la.

\subsubsection{Coleta dos exames de sangue}

No início da investigação, adotou-se como regra que os participantes seriam entrevistados no primeiro contato com o investigador, deixando-se a coleta de sangue para um outro dia. Como este procedimento era realizado por uma auxiliar de enfermagem da penitenciária, que cumpria outras atividades e não estava integralmente disponível para a coleta, ele só podia ser executado uma ou duas vezes por semana. Com isso, alguns presos não compareceram à coleta nos dias subseqüentes, representando a perda de 12 indivíduos que já haviam sido submetidos ao questionário. A adoção de uma outra metodologia, em que uma enfermeira passou a ser levada diariamente ao presídio com vistas a colher a amostra de sangue logo após a entrevista, eliminou por completo o índice de perdas devidas a não retornos.

\subsection{Discussão dos Resultados}

\subsubsection{Aspectos descritivos da população estudada}

Conforme descrição anterior, a participação na pesquisa foi incrementada após envolvimento dos "enfermeiros" de cada pavilhão. A despeito deste auxílio, o de número 4 teve a menor contribuição de participantes em relação aos demais $(32,9 \%)$, porque muitos sorteados recusaram participar e vários desistiram da coleta de sangue. Segundo os funcionários do presídio, a baixa adesão era esperada em virtude destes presos apresentarem maior dificuldade na comunicação e relacionamento, além de problemas de indisciplina, deficiências de higiene e resistência ao desempenho de atividades relacionadas ao trabalho. A participação expressiva do pavilhão $1(46,0 \%)$ reflete a destacada atuação de seus integrantes em áreas diversas da penitenciária. Conforme relato de assistente social, estes sentenciados têm marcante envolvimento nas atividades de re-inserção à sociedade e estão sempre interessados em desempenhar alguma espécie de trabalho. Como exemplo, todos os que compõem a cozinha são integrantes desse pavilhão. 
No que diz respeito a variável idade, percebe-se que a população estudada é basicamente jovem, com maior número de indivíduos de 19 a 30 anos (61,0\%). A idade média dos presidiários (30,1 anos) ficou acima dos valores verificados no

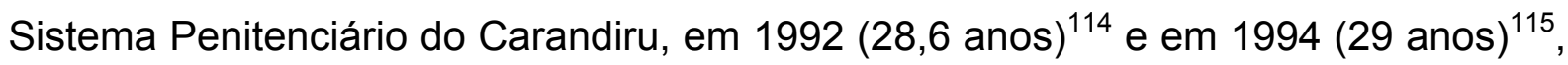
assim como na cidade de Sorocaba-SP ${ }^{104}$. Em outros países, encontrou-se 28 anos em Nyborg (Dinamarca) ${ }^{116}$, 27,2 em prisões da Cantabria e León (Espanha) ${ }^{117,118} \mathrm{e}$ 26,2 em Maputo, Moçambique ${ }^{6}$. A amplitude de variação da idade é larga, indo de um mínimo de 19 anos, onde concentra boa parte dos sentenciados, ao máximo de 69 anos, representado por um único preso. Embora chame atenção, estes valores não estão distantes em relação ao encontrado em Moçambique ${ }^{6}$. Esses achados confirmam que as atividades criminais (furto, roubo, homicídio, etc) são cometidas, majoritariamente, por indivíduos jovens.

Praticamente há uma divisão pela metade entre os participantes que nasceram na cidade de Ribeirão Preto e região $(52,9 \%)$, e os de outras áreas do Estado de São Paulo e outros Estados (47,1\%). Isso é conseqüência do recebimento de muitos presos de outras instituições do Estado por conta de super lotação de algumas delas, ou inativação de outras, como as prisões do Complexo do Carandiru. Quando se analisam estas regiões como local de residência, se constata que mais de três quartos mora em Ribeirão Preto e região (34,8\% e 40,9\%, respectivamente). Este achado pode ser em razão do grande potencial econômico da região de Ribeirão Preto, empregando milhares de migrantes vindos de outros Estados e regiões do Estado de São Paulo. Soma-se a isso, o deslocamento das famílias dos presos de outras regiões, sobretudo da cidade de São Paulo, transferidos para esta penitenciária para morar mais próximo dos seus. Assim, quando inquiridos sobre local de residência, os participantes referem aquele onde se localiza a sua família no momento atual, elevando os percentuais correspondentes à cidade e à região. O município que melhor representa esta situação é o de Serrana, onde se instalaram muitos familiares que vieram da Grande São Paulo acompanhando seus parentes originários do Carandiru. Como comparação, em 1992, 65,8\% dos reclusos no Carandiru referiram ter nascido no Estado de São Paulo $^{115}$. Já na cidade de Sorocaba-SP, em estudo semelhante, encontraram-se valores de $16,0 \%$ de nascidos e de $32,0 \%$ de moradores da cidade e da região ${ }^{104}$.

Foram considerados como tendo parceria fixa e estável todos aqueles que referiram ser casados ou amasiados. Vale o destaque para os últimos, que 
representam quase metade de todos os participantes $(49,0 \%)$. Isto denota o alto nível de união civil informal, provavelmente reflexo da mesma ocorrência fora dos muros da prisão. Informalmente, alguns presos relataram que o início de um relacionamento algumas vezes se dá dentro do próprio presídio, com mulheres que seriam amigas ou parentes de colegas encarcerados. Se estes encontros persistirem nas próximas visitas, o preso já se considera "amasiado" e exige o mesmo grau de compromisso da parceira. Neste estudo, a divisão entre "casados" e "não-casados" mostra predomínio do primeiro (58\%), com um valor próximo ao verificado em prisões da Zâmbia $(59,5 \%)^{24}$ e abaixo de outras descrições: $54 \%$ em SorocabaSP ${ }^{104} ; 48 \%$ em Ghaziabad, na Índia ${ }^{4}, 40,0 \%$ em León, Espanha ${ }^{120}$ e 34,5\% em Bancoc, Tailândia ${ }^{121}$.

A carga de doenças infecciosas entre presidiários é bastante elevada, tanto entre os que entram, como entre os que permanecem e os que saem das prisões. Este fato é demonstrado por dados de 1997 referentes à totalidade da população americana, na qual Hammett et al. ${ }^{122}$ mostraram que já haviam passado pelo sistema penal cerca de 20 a $26 \%$ dos portadores de HIV, 29 a $43 \%$ dos portadores de hepatite C e $40 \%$ dos que tiveram tuberculose. Já Mertz et al. ${ }^{123}$, também nos EUA, mostraram que portadores de diferentes DSTs (sífilis, gonorréia e clamídia) deram entrada em diversas instituições penais, inclusive juvenis, nos anos de 1997 a 1999.

Como nossa situação certamente não se mostra melhor, intervenções se tornam necessárias para beneficiar não somente aos sentenciados e suas parcerias, mas a todo o sistema carcerário. Com este pensamento, a Penitenciária de Ribeirão Preto procura desenvolver, periodicamente, programas preventivos de DSTs e doenças transmitidas por contato com sangue. Além disso, há uma preocupação especial em fazer investigação de doenças, principalmente as mencionadas acima, entre os que adentram o presídio. À entrada, o preso se submete a uma avaliação médica e à aplicação de um questionário com perguntas a respeito de sua saúde. Entre elas, se é portador do HIV e se já realizou testes para este vírus. Ao final, é oferecida a possibilidade deste exame, mesmo que o sentenciado se declare não portador. Esta prática explica o elevado percentual de participantes $(58,3 \%)$ que já havia sido submetido a pelo menos um exame anti-HIV, semelhante ao referido em prisões de Ontário, no Canadá $(57,6 \%),(343 / 595)^{124}$ e superior ao descrito em Glenochil, na Escócia $(44,3 \%)^{100}$. Mesmo que uma parte destes exames tenha sido 
feita fora da prisão, observa-se uma política de busca ativa de portadores do HIV, dentro de um contexto intimamente favorável à sua presença. Segundo Varghese \& Peterman ${ }^{125}$, a prática de oferecimento de sorologia, além de prevenir novos casos, diminuiria a necessidade de recursos financeiros para assistência e tratamento de futuros portadores, trazendo vantagens econômicas.

Com esta preocupação, 16 estados norte americanos implementaram o teste obrigatório na entrada de todo preso no sistema carcerário ${ }^{126}$, causando intenso debate a respeito dessa política de prevenção. Um destes estados, Rhode Island, obriga o teste após o indivíduo passar da detenção à condenação. Como conseqüência desta política, em 1990, mais de 40\% dos diagnósticos de HIV desta unidade federativa vieram de sua única prisão ${ }^{127,150}$. A argumentação dos contrários à obrigatoriedade é a subseqüente segregação dos indivíduos cujos testes resultarem reagentes, por parte daqueles com resultados negativos e pelos funcionários da prisão, como descrito na Califórnia e em Taiwan ${ }^{128,155}$.

Na prisão de Ribeirão Preto, o exame sorológico para o HIV não é obrigatório, seguindo as recomendações da $\mathrm{OMS}^{129}$ e do manual "AIDS e Ética Médica" do Conselho Regional de Medicina do Estado de São Paulo ${ }^{130}$, que diz no tópico "Exame Compulsório":

"É vedada a realização compulsória de sorologia para HIV, em especial como condição necessária à internação hospitalar, pré-operatório, ou exames pré-admissionais ou periódicos e, ainda, em estabelecimentos prisionais".

Vale ressaltar que $26,7 \%$ dos participantes realizaram o teste uma única vez, enquanto $31,6 \%$ deles o fizeram por mais de uma vez. Não obstante, 135 indivíduos $(40,5 \%)$ nunca haviam sido submetidos ao exame, o que recomenda a introdução do aconselhamento como uma medida complementar ao oferecimento do teste. $\mathrm{O}$ aconselhamento é uma prática de atendimento em saúde centralizada no indivíduo, que pressupõe uma disposição para escutar e acolher com atenção as demandas e necessidades trazidas por ele. Este atendimento busca estabelecer uma relação de confiança, baseada na linguagem acessível e na ausência de coerção. No caso em questão, deverá haver a garantia do retorno do resultado, seja ele reagente ou não.

$\mathrm{Na}$ população estudada, o consumo de drogas ilícitas não injetáveis no passado englobou fundamentalmente três produtos - maconha, cocaína de uso inalatório e o crack -, usados de modo isolado ou combinado. Outros tipos usados 
em menor escala foram cola, LSD, haxixe e ectasy. O percentual de uso dessas drogas foi extremamente elevado $(81,4 \%)$, com predomínio acentuado na população de até 30 anos $(p=0,001)$, apesar de uso considerável também naqueles acima desta idade. Este valor é muito próximo do encontrado em duas unidades da FEBEM, em São Paulo $(90 \%)^{16}$. No Complexo do Carandiru, em 1990, o uso de drogas por via não injetável alcançou $47,6 \%{ }^{114}$, saltando para 55,5\% em 1994 , somente na Casa de Detenção de São Paulo (unidade do Carandiru) ${ }^{137}$.

Isoladamente, a maconha foi utilizada por $39,8 \%$ dos participantes que usaram algum tipo de droga. Este percentual sobe para 46,5\% quando ela é associada a outras drogas. Em unidade correcional para adolescentes no Espírito Santo, observou-se utilização da maconha por $50,5 \%$ dos jovens ${ }^{138}$, tendo chegado a $84 \%$ na $\mathrm{FEBEM}^{16}$. Em prisões da Inglaterra, observou-se que $34 \%$ dos presos utilizavam maconha antes do encarceramento ${ }^{140}$.

A maconha, Cannabis sativa, é a droga ilícita mais largamente consumida em muitas sociedades, principalmente ocidentais, não obstante seu uso ser proibido por lei. Seus efeitos para a saúde não são bem compreendidos e permanecem objetos de muita discussão, com opiniões polarizadas, inclusive no que concerne à legalização. Seu uso é intermitente e geralmente termina dos 25 aos 30 anos. Seus efeitos adversos podem ser agudos ou crônicos, com manifestação de bronquite crônica, ansiedade, pânico, distúrbios de memória e de atenção ${ }^{131,132}$. A iniciação da maconha é precedida pelo uso de substâncias lícitas (tabaco e álcool) e geralmente é a primeira droga ilícita consumida. Se utilizada precocemente (antes dos 17 anos), pode aumentar o risco de progressão para dependência ou para uso de outros tipos de substâncias ${ }^{133,134}$. Paralelamente a isso, esta seqüência de drogas a partir da maconha pode também estar associada a diversos fatores, tais como pressão dos amigos, influência do tráfico, disponibilidade da droga e outras ${ }^{135}$. Os delitos que levam a uma condenação estão intrinsecamente relacionados ao uso de drogas, com crimes como homicídios, roubos e furtos sendo, em grande parte, praticados sob sua influência. Todavia, prisões e condenações relacionadas a infrações por porte ou uso de maconha não necessariamente significam redução em sua utilização, podendo mesmo levar a um incremento em seu consumo ${ }^{136}$.

Chama a atenção o baixo consumo de crack, que atinge apenas $1,8 \%$ dos participantes como droga usada isoladamente, e 22,2\% quando se associa a outros tipos. Estes números são muito próximos do observado em prisões da Inglaterra 
$(1 \%)^{140}$ e inferiores aos descritos em Los Angeles $(58,6 \%)^{139}$. Apesar de ter sido introduzido no Brasil no final da década de 1980 e início da década de 1990, o seu uso está bastante difundido e acha-se intimamente ligado à baixa escolaridade, baixo nível socioeconômico, desemprego e, sobretudo, a uma taxa mais elevada de criminalidade.

Diferentemente da elevada distribuição das drogas ilícitas não injetáveis, o uso das injetáveis anteriormente ao encarceramento foi referido por $8,7 \%$, mostrando uma distribuição maior entre indivíduos acima dos 30 anos $(p=0,008)$. A título de comparação com o passado recente, Lourenço, em pesquisa realizada em 1990, constatou predomínio de UDI na população de até 30 anos $(79 \%)^{114}$. Trazendo esta faixa etária para os dias de hoje, percebe-se que é correspondente a mais prevalente nesta pesquisa. Aparentemente, o consumo dessas drogas constituía um hábito comum no passado, porém bem menos freqüente entre os mais jovens atuais. Importante lembrar que este consumo estava fortemente associado a compartilhamento de agulhas e seringas, prática que vem sendo alvo de constantes campanhas com vistas a reduzir o risco de contração de doenças transmitidas por contato sangüíneo. O oposto é encontrado em países da Ásia Central e Leste Europeu, aonde o consumo de drogas injetáveis vem mostrando elevação, e se estima que acima de $1 \%$ da população - sobretudo a camada mais jovem -, utiliza drogas injetáveis. Um estudo entre estudantes secundaristas da cidade de Moscou mostrou que $4 \%$ são UDI, muitos com idade entre 13 e 14 anos $^{141}$. Na presente pesquisa, chama à atenção a ausência de UDls acima de 45 anos, o que talvez decorra do reduzido número de participantes neste grupo etário (15).

\subsubsection{Resultados do estudo de associação de marcadores do HIV com fatores de risco.}

Apesar do Ministério da Saúde adotar a política de exigir dois testes sorológicos reagentes para considerar um indivíduo portador do HIV, algumas razões fizeram com que, na presente pesquisa, se adotasse um único teste. Dos 19 presidiários com sorologia reagente, 13 já tinham conhecimento de sua condição de portador do HIV, inclusive fazendo seguimento ambulatorial. Dos 6 participantes que foram diagnosticados na investigação, apenas 4 colheram a segunda amostra para a confirmação. Dos dois restantes, um foi transferido de penitenciária (laudo 
transmitido por telefone e cópia por fax para o médico responsável) e o outro se recusou a coletar uma segunda amostra.

A prevalência do HIV nas prisões sempre apresentou valores marcantemente superiores ao encontrados na população, desde quando pesquisas foram iniciadas, em meados da década de 1980. No presente estudo, foi encontrada uma taxa quase sete vezes mais alta que a estimada para a população masculina brasileira, que é de $0,84 \%{ }^{142}$. Entretanto, os $5,7 \%$ achados aqui situam-se bem abaixo dos níveis observados na maioria dos estudos nacionais, muito embora ocorra grande variação entre diferentes unidades prisionais. Assim, em 1987, não foi encontrado nenhum portador do HIV nos 57 indivíduos investigados na Cadeia Pública de Sorocaba ${ }^{143}$. Em contrapartida, uma das primeiras pesquisas realizadas no Complexo do Carandiru, em 1988, evidenciou 12,5\% ${ }^{144}$. Na Casa de Detenção do Carandiru, em 1990 , encontrou-se uma prevalência de $17,3 \%{ }^{145}$. Ainda no mesmo ano, estudo com 1692 presidiários que foram avaliados quando da admissão neste mesmo complexo penitenciário, revelou 16,5\% ${ }^{114}$. Na Cadeia Pública de Londrina-PR, em 1991, verificou-se um valor de $6,3 \%{ }^{146}$. Em 1993, uma prevalência de 7,5\% foi encontrada em cadeias das cidades de Mogi das Cruzes e Suzano, no Estado de São Paulo ${ }^{111}$. Duas pesquisas realizadas paralelamente na Casa de Detenção do Carandiru, nos anos de 1993 e 1994, mostraram prevalências de 13,7\%, em 766 avaliados $^{137}$, e de 16\%, em 631 participantes ${ }^{115}$. Em 1996, foram achados valores iguais a 14,4\% em Campinas-SP ${ }^{17}, 12,6 \%$ em dois presídios de Sorocaba-SP ${ }^{104}, 3,2 \%$ em Manhuaçu$\mathrm{MG}^{8}, 1,6 \%$ em Fortaleza-CE ${ }^{18}$ e $4,9 \%$ no Rio de Janeiro ${ }^{147}$. Vale mencionar dois trabalhos em sistema correcional para adolescentes. Um deles na FEBEM, em 1994, evidenciou $3,2 \%{ }^{16}$, enquanto o outro, no Espírito Santo, em 1999, encontrou $4,8 \%{ }^{138}$. Da análise destes achados, percebe-se que as prevalências são acentuadamente maiores nas prisões de cidades do Estado de São Paulo. Vale mencionar, contudo, que todos foram realizados há pelo menos sete anos, possivelmente não exprimindo a realidade atual. Números elevados, especialmente no Complexo do Carandiru refletem aquele momento, com uma epidemia crescente em conseqüência de comportamentos inseguros e uma total ausência de política para combate da expansão do HIV. Grandes consumidores de drogas injetáveis compartilhavam suas agulhas com colegas, favorecendo a disseminação viral. À esta época, o percentual de UDI nos portadores de AIDS girava por volta dos $30 \%{ }^{25}$. Sexo sem proteção, com mulheres ou mesmo entre colegas encarcerados, 
colaborava para manutenção de níveis absurdamente elevados, como o encontrado por Varella et al. em 1990 entre travestis no Carandiru, correspondendo a $78 \%$ de contaminados $^{145}$. Atualmente, a situação é outra, com programas específicos dentro e fora da via institucional - que tratam exclusivamente da AIDS no sistema penitenciário. Atuações nas áreas preventivas e de assistência procuram dar uma nova perspectiva a esta situação dentro do ambiente prisional.

Nos EUA, inúmeras investigações surgiram após a descrição dos primeiros presidiários - sete no total - com a síndrome da imunodeficiência adquirida ${ }^{28}$. Com uma população carcerária que ultrapassa a casa dos 2 milhões de indivíduos, o País tem a mais elevada taxa de aprisionamento (702 por 100.000 habitantes), alcançada em junho de $2002^{148}$. Segundo Spaulding et al. (2002) ${ }^{149}$, simultaneamente com a emergência do HIV, aquele País experimentou um aumento na sua população carcerária de 5,6\% por ano, ocasionando uma quase duplicação ao longo dos últimos 12 anos. Estas duas "epidemias" - HIV e encarceramento - se intrarelacionaram. Como exemplo, cita-se a mudança do padrão de mortalidade de algumas prisões do estado de Maryland, em 1987. Neste ano, a AIDS foi a causa principal de óbito, superando os antigos líderes, doenças do sistema circulatório, suicídio e homicídio ${ }^{151}$. De acordo com Hazel \& Fleming $(1999)^{3}$, em 1996, a taxa de casos notificados de AIDS em prisões americanas foi de 199 por 100.000 presos, praticamente seis vezes o valor de 31 por 100.000 da população geral dos EUA.

Vlahov et al. (1991) ${ }^{152}$ realizaram um dos maiores estudos de soroprevalência em presídios americanos, nos anos de 1988 e 1989. No momento da entrada nestas prisões, observaram 4,3\% de sorologia reagente entre 10.994 homens e mulheres. Em 1983, em prisão militar de segurança máxima, foi evidenciada presença de anticorpos anti-HTLV-III (ainda não denominado HIV) em 1\% dos presos ${ }^{105}$. Outras publicações em estabelecimentos americanos mostraram: 2,4\% em unidades do estado de Nevada ${ }^{99} ; 2,4 \%$ e 1,4\%, em 1994 e 1999, respectivamente, na Califórnia $^{23} ; 0,3 \%$ em lowa ${ }^{153} ; 2,6 \%$ no Texas $^{154} ; 3,3 \%$ em Maryland ${ }^{12}$.

Em outras partes do mundo, as prevalências também apresentam ampla variação. Em 1987, Harding ${ }^{93}$ levantou dados de 16 países do Conselho da Europa, encontrando taxas das mais distintas: $0,1 \%$ na Inglaterra; $1,3 \%$ na Bélgica; $2,1 \%$ em Luxemburgo; $11 \%$ na Suíça; $26 \%$ na Espanha; $16,8 \%$ na Itália; $12,6 \%$ na França.

A título de comparação, alguns valores da prevalência do HIV merecem destaque: 0,1\% em Liverpool, Inglaterra ${ }^{156} ; 2,4 \%$ em Glenochil, Escócia ${ }^{100} ; 3,4 \%$ em 
Edimburgo, Escócia ${ }^{157} ; 2 \%$ no Canadá ${ }^{158} ; 1,5 \%$ na Austrália ${ }^{159} ; 6 \%$ na Etiópia ${ }^{160}$; 1,1\% no Peru ${ }^{161} ; 25,4 \%$ em Bancoc, Tailândia ${ }^{121} ; 26,9 \%$ e 33,6\% respectivamente na Catalunha e em Córdoba, Espanha ${ }^{163,165}$.

No presente estudo, os portadores se concentraram, principalmente, nos pavilhões 1 e 2, sem que se perceba nenhum motivo especial para esta distribuição. O achado de maior prevalência na faixa etária de 31 a 35 anos se assemelha ao encontrado na população masculina brasileira, que tem neste grupo o maior número de casos notificados $(23 \%)^{25}$. Este dado é compatível com os encontrados em Campinas $^{166}$, Sorocaba ${ }^{104}$, Dublin (República da Irlanda) ${ }^{162}$ e com a epidemiologia geral dos encarcerados americanos ${ }^{3}$. Em um dos vários trabalhos no Carandiru, Lourenço (1996) $)^{114}$ observou maior predomínio (23\%) nos indivíduos com idade de 21 a 25 anos. Já em prisões do sudeste da França ${ }^{164}$, a maior prevalência da AIDS foi no grupo etário de 26 a 30 anos. A distribuição pela variável idade tem grande importância no estudo da epidemiologia do HIV, principalmente por refletir aspectos comportamentais de risco ao longo da vida, como atividade sexual desprotegida e uso de drogas injetáveis. Como exemplo deste último, Martin et al. $(1990)^{163}$ descreveram que os UDI tiveram um risco maior à contaminação do HIV quando adotaram este comportamento antes dos 16 anos. Apesar da relevância dessa variável, a maior quantidade de indivíduos soropositivos acima dos 30 anos, na presente pesquisa, não se mostrou estatisticamente significante nas análises uni e multivariada.

Merece comentário o nível extremamente reduzido do grau de educação da população do estudo. Praticamente $60 \%$ dos envolvidos tinham menos de 6 anos de escolaridade, o que mostra uma dificuldade de acesso à escola ou, mais provavelmente, o abandono precoce. A retirada do individuo do seio da sociedade para o cárcere, ou o próprio envolvimento em atividades ilícitas, também podem funcionar como determinantes de um baixo nível de escolaridade. Vale salientar a presença de investigados que referiram ter dado continuidade aos estudos, ou mesmo concluído o ensino fundamental, dentro da própria instituição penal. Segundo Fonseca et al. $(2000)^{73}$, renda, ocupação e nível educacional são importantes indicadores das condições de saúde da população. Este último é o de maior valor entre todos, por ser mais fácil de ser obtido e ter grande peso como determinante de saúde. De forma consistente com isso, na presente pesquisa verificou-se maior concentração de positivos ao HIV nos sentenciados de baixa 
escolaridade, muito embora essa diferença não tenha atingido o limite da significância estatística. Vale ressaltar que o acometimento progressivamente maior de indivíduos de pior nível socioeconômico, para a população como um todo, é uma tendência que vem sendo observada no Brasil em anos recentes. Entre presidiários, o padrão de prevalência elevada de HIV sempre se manteve naqueles de menor escolaridade $^{104,114}$. O mesmo fato é descrito em outros países, mesmo nas situações em que os reclusos apresentam mais anos de estudo do que os brasileiros $^{103,117,121,167}$.

Ao contrário de observações feitas no Carandiru ${ }^{114}$ e em León, na Espanha $^{120}$, não se observou diferença estatística na presença do anti-HIV em relação ao tempo de pena já cumprido. Em contrapartida, verificou-se associação da presença do marcador com o tempo total da pena, com prevalência mais elevada entre os que foram condenados a tempos mais curtos (até 5 anos) de reclusão. Intuitivamente, seria de se pensar que o risco de infecção deveria estar associado com tempos mais longos passados na cadeia, e não o contrário. Uma possível explicação para o achado talvez resida no fato de que grandes delitos (homicídio, tráfico de drogas), que levam a longas penas, não necessariamente estejam associados com comportamento de risco para aquisição do HIV. Já os crimes mais brandos (porte de droga ilícita, porte ilegal de arma e pequenos furtos) muitas vezes são motivados pela necessidade de sustentar a dependência a drogas. Esta situação, por sua vez, pode ser ligada a outros comportamentos de risco, tais como multiplicidade de parceiros e outras práticas de sexo inseguro.

Dos 19 participantes com sorologia reativa,15 já tinham se submetido pelo menos a um teste anti-HIV, com 13 estando cientes de seu estado sorológico reagente e 2 da sua condição de negativo. Conclui-se, portanto, que esses dois presidiários soroconverteram após o último exame realizado.

A presença de ulceração genital, ou rompimento de mucosa causado por infecções, surge como um dos fatores mais consistentes na transmissão e aquisição do HIV, através do contato sexual ${ }^{37}$. É consenso que as DSTs elevam a disseminação do HIV, hipótese sugerida pela primeira vez por Piot et al. $(1984)^{168}$. Diversas publicações têm demonstrado que a existência das DSTs em um dos parceiros aumenta enormemente o risco de contágio, assim como a suscetibilidade ao vírus ${ }^{169-173}$. Excluindo-se o HIV, e como fator de risco para este, as DSTs têm prevalências consideráveis dentro das prisões, inclusive juvenis ${ }^{174}$. Como exemplo, 
em Moçambique, 34\% dos presidiários referiram passado de DST não ulcerativa e $4 \%$ de DST ulcerativa ${ }^{6}$. A DST do tipo ulcerativa tem um impacto maior do que a não ulcerativa no processo de transmissão do HIV ${ }^{175-177}$, com evidências de que o homem é mais afetado do que a mulher pelos efeitos dessas doenças na suscetibilidade ao vírus ${ }^{177}$. O desencontro do presente trabalho com a literatura, em relação à não associação estatística entre doença ulcerativa e marcador sorológico, pode ser decorrente de apenas dois portadores do HIV terem relatado DST ulcerativa no passado.

A associação DST não ulcerativa e HIV alcançou significância apenas na análise univariada, não se confirmando posteriormente. Destaca-se a elevada referência a antecedentes de DSTs não ulcerativas (30,6\%), acima do observado no Carandiru (23,7\%), em $1992^{114}$ e, principalmente, na FEBEM $(12 \%)^{16}$.

Vários relatos mencionam contato sexual entre os encarcerados, dentro das prisões. Este estudo não apontou nada neste sentido, e uma possível explicação pode estar relacionada ao estigma associado ao assunto, fazendo com que as pessoas negassem essa prática. Adicionalmente, há que se considerar que a preferência sexual naquele ambiente poderia ser circunstancial. $O$ indivíduo estaria e não seria homossexual, por uma série de motivos, entre os quais predominaria a coerção. O único recluso que assumiu sua condição homossexual já tinha conhecimento prévio de seu anti-HIV e comentou ter sido essa a causa da infecção. Achado semelhante foi descrito por Power et al. $(1991)^{179}$, relatando somente um participante com prática homossexual em grupo de 559 presos na Escócia. No entanto, são em maior quantidade os trabalhos relatando presidiários homossexuais com prática dentro dos presídios ${ }^{14,24,97,104,114,115,137,180}$. Na presente investigação, mesmo com apenas um indivíduo reconhecendo sua condição de homossexual, a variável mostrou associação com a infecção pelo HIV dentro de um intervalo de credibilidade de $10 \%$.

A multiplicidade de parceiras não se revelou fator de risco para contaminação pelo HIV, com $89,5 \%$ dos pacientes reagentes relatando menos de 10 parceiras no ano anterior à prisão. Fato semelhante já havia sido descrito em prisões da França $^{164}$.

Embora não representado em tabela, merece destaque o relato de baixo percentual de uso de preservativo na visita íntima $(20,7 \%)$. Provavelmente este achado esteja associado à idéia de irrestrita confiança em relação a uma 
companheira que supostamente tem somente o próprio presidiário como parceiro. Nessas condições, a utilização da camisinha traria à relação sexual um certo caráter de suspeição. Tourinho \& Dourado $(2002)^{183}$, mostraram que o conhecimento dos modos de transmissão do HIV não foi acompanhado pela prática sexual segura, com $59,5 \%$ dos estudados não usando camisinha nas suas relações. No presente estudo, alguns participantes informaram que não as utilizavam pelo não distribuição por parte dos agentes carcerários, acusação essa rebatida pela direção da penitenciária, que afirma que o fornecimento é constante e sem limites. A plena entrega de preservativos é um dos pilares básicos de prevenção da AIDS do Programa Nacional nas prisões, diferentemente dos EUA, onde praticamente não existe tal prática ${ }^{181,182}$. Na Inglaterra, Green et al. $(2003)^{119}$ descreveram que a maioria dos presidiários teve envolvimento sexual de alto risco com UDIs e prostitutas, no interior de prisões daquele País.

A hipótese de que a circuncisão possa servir de barreira à difusão da AIDS por via sexual foi levantada inicialmente há mais de 15 anos ${ }^{184}$. Desde então, muitos estudos epidemiológicos incluíram a não circuncisão como fator de risco em potencial para infecção pelo HIV, levando à proposta da sua realização como medida capaz de reduzir a contaminação ${ }^{185-188}$. Na verdade, a relação da circuncisão com as DSTs já vem sendo observada há várias décadas, como mostra um levantamento feito com soldados da II Guerra Mundial, onde se percebeu que mais de $90 \%$ dos casos de sífilis ocorriam nos não circuncidados ${ }^{189}$. Uma das explicações para a proteção, segundo Szabo \& Short ${ }^{190}$, se basearia no fato do epitélio estratificado, escamoso e queratinizado dos circuncidados proporcionar uma barreira de impedimento ao HIV, ausente nos não circuncidados pela inexistência de queratina internamente ao prepúcio. De acordo com Kiwanuka et al. (1999) ${ }^{192}$, essa idéia de bloqueio ao HIV estaria mais fortemente vinculada aos indivíduos submetidos a esse procedimento antes dos 12 anos de idade. Eyer-Silva (2003) ${ }^{191}$ afirma que a principal limitação desses estudos é a possibilidade de concorrência de fatores de confundimento. Na presente investigação, embora a associação não tenha alcançado significância ao nível de $5 \%$ na análise univariada, a sua inclusão no modelo multivariado revelou que a variável tem um papel preditor independente de infecção pelo HIV, com intervalo de credibilidade de 10\%. Destaca-se o baixo número de participantes circuncidados $(7,8 \%)$ e a ausência de informações sobre este item em investigações realizadas no Brasil. 
Apesar de não ter sido discriminado o tipo de droga consumida pelas parcerias dos presos, é de se supor que grande parte usava drogas não injetáveis. De qualquer forma, os usuários de drogas ilícitas mostram tendência a ter múltiplos parceiros sem uso de preservativos, levando, principalmente, a um maior potencial de contaminação pela via sexual ${ }^{87}$. Por outro lado, os UDIs que compartilham agulhas e seringas têm, concretamente, maior risco de levar este vírus adiante por práticas sexuais não protegidas ${ }^{193}$. A análise multivariada não demonstrou associação estatística da infecção pelo HIV com relacionamento sexual com usuários de drogas ilícitas, embora $68,4 \%$ dos participantes com sorologia positiva tenham referido esse antecedente. Merecem registro os achados de elevados percentuais de uso de drogas ilícitas pelo menos uma vez na vida $(81,4 \%)$ e de com sexo com usuárias de drogas (45,6\%). Este último pode ser mais elevado, uma vez que o uso dessas substâncias em parcerias eventuais pode passar despercebido aos seus contactantes.

Indubitavelmente, uso de drogas injetáveis e compartilhamento de agulhas e seringas são os itens mais associados à transmissão do HIV dentro dos presídios $^{15,139,149,156-159,162,194}$. Para se ter dimensão da presença deste hábito no sistema penal, 61\% dos presos norte americanos com AIDS, de 1994 a 1996, eram $\mathrm{UDI}^{3}$. Este modo de transmissão sanguínea ocorre devido à alta prevalência de UDls dentro do sistema carcerário, levando a crer que este apresenta maior quantidade de indivíduos com tal comportamento do que os centros de reabilitação para dependentes químicos ${ }^{195}$.

A investigação de uso de drogas injetáveis se baseou em seu uso em algum momento da vida, no passado e/ou no presente. $O$ fato de nenhum participante ter relatado essa prática no presente levanta alguns questionamentos sobre possibilidade de viés de resposta. A negativa de uso no interior do presídio pode, primeiramente, ser em virtude do estigma associado a esse comportamento reprovado pelo senso comum e punido criminalmente - e, em seguida, o temor de represálias em assumir uma conduta ilegal. Soma-se a isso, o fato da aplicação do questionário ter sido feita em ambiente sujeito a aparição de transeuntes, induzindo o recluso a respostas falsamente negativas.

A presença do HIV foi mais de 10 vezes maior nos presos que admitiram uso passado de drogas injetáveis $(34,5 \%)$ e de até 17 vezes entre os que assumiram o compartilhamento de agulhas e seringas $(63,6 \%)$, mostrando forte associação 
estatística para ambas as variáveis $(p=0,000)$. Por conseguinte, o uso e o compartilhamento passado de agulhas e seringas funcionaram como os fatores que mais intensamente se mostraram capazes de predizer de modo independente a positividade do HIV.

Para comparações, no Carandiru, $51,9 \%$ dos portadores eram UDI em $1990^{114}, 43,3 \%$ em $1993^{115}$. Outras publicações mostram: 35\% em Sorocaba ${ }^{104}$; 0,5\% em Londres ${ }^{196} ; 52,7 \%$ em Bangcoc, Tailândia ${ }^{121} ; 2,4 \%$ no Canadá $^{197} ; 0 \%$ na Dinamarca ${ }^{116} ; 59,3 \%$ em Tijuana, México ${ }^{97}$. Cotejando com presos que compartilharam agulhas e seringas, $61,6 \%$ eram anti-HIV positivo na Espanha ${ }^{167}$, $56,8 \%$ na França ${ }^{164}$ e $3,5 \%$ na Irlanda ${ }^{14}$.

Transfusão sanguínea não se mostrou estatisticamente associada à infecção pelo HIV, apesar de $12,5 \%$ dos soropositivos relatarem ter se submetido a este procedimento no passado. Embora a transfusão seja a mais eficiente forma de transmissão do $\mathrm{HIV}^{198}$, seu risco, atualmente, é próximo de zero, pelos procedimentos de triagem sorológica realizados nos bancos de sangue. Embora existam poucas referências na literatura a transfusões sanguíneas em prisões, merecem destaque os achados de $5 \%$ em estudo no Carandiru ${ }^{114}$ e 11,6 na Espanha $^{167}$.

Apesar do modelo multivariado não ter revelado associações entre HIV e icterícia e hepatite no passado, este fenômeno pode se fazer presente em virtude da freqüência da co-infecção HIV e vírus da hepatite $B$, em decorrência da similaridade dos mecanismos de transmissão. Este fato pode ser ilustrado pelos achado de Rotily et al $(1994)^{164}$, relatando história de hepatite B em $50 \%$ de sentenciados com marcador positivo para HIV.

Em 1988, Doll relatou a provável contaminação com HIV através de tatuagem, em dois presos nos Estados Unidos ${ }^{199}$. Associação desse fator com a infecção pelo HIV foi descrita na Espanha ${ }^{118}$ e na Zâmbia ${ }^{24}$. No presente estudo não houve associação estatística de tatuagem com infecção pelo HIV.

\subsection{Consideraçoes Finais}

Desde o início da epidemia de AIDS, as pessoas confinadas têm sido objeto de grande preocupação por parte dos programas de controle, uma vez que reúnem riscos comportamentais e ambientais que as conduzem à elevada probabilidade de infecção. As prisões brasileiras sintetizam de modo eloqüente esta situação. 
Números distintos de prevalência do HIV nos encarcerados surgiram desde o final da década de 1980, mas até o momento não existe uma contabilização total da realidade do País. A verdadeira situação é desconhecida, em parte pela pouca priorização conferida a estudos epidemiológicos entre presidiários, e em parte porque grande parte dos presos se concentra em instituições menores do que as penitenciárias, como cadeias públicas, delegacias de policia (DPs) e centros de detenções provisórias (CDPs). Estes estabelecimentos, ao invés de serem usadas para detenção de suspeitos logo após sua prisão, e por um curto espaço de tempo, mantêm detentos por longos períodos, até mesmo anos.

No entanto, os escassos dados disponíveis apontam para o fato de que a AIDS no sistema penal está vinculada à origem socioeconômica, baixa escolaridade, relações conflituosas com a família e a comunidade de origem, freqüência de práticas de risco representadas pelo uso de drogas e múltiplas relações sexuais não protegidas. A estes determinantes sociais, somam-se as condições institucionais desfavoráveis ao desenvolvimento de programas educativos.

A carência de serviços de saúde estruturados é notória, mesmo em prisões previamente definidas com estes dispositivos. As atividades de prevenção e assistência necessitam de incremento, sobretudo no que se refere a profissionais capacitados para executá-las. Além da falta de recursos, esta situação é fruto de reduzido número de programas educacionais para a saúde e falta de articulação com o Sistema Único de Saúde (SUS). Mesmo assim, algumas instituições, como a Penitenciária de Ribeirão Preto e outras, têm superado as barreiras e procurado fazer frente à epidemia do HIV.

A penitenciária em estudo tem um serviço de saúde razoável, com boa disponibilidade de materiais básicos, pecando, porém, pela falta de recursos humanos nas diversas áreas que se fazem necessárias (médico, enfermeiro, farmacêutico, auxiliar de enfermagem, e outros). Dessa forma, as atividades de assistência e prevenção à AIDS são limitadas e não contínuas.

A prevalência inferior do HIV, comparada a pesquisas anteriores, pode ser devida a diferentes fatores, tais como: a própria estabilização da doença no país, acompanhada da mudança de comportamento dos UDI no sentido de não compartilhamento de agulhas e seringas, bem como da substituição do uso de drogas injetáveis por inalantes ou outras. Além disso, pode ser devida também ao aumento da percepção do risco à contaminação do HIV em suas diferentes formas 
de transmissão. Por fim, mesmo que de alcance ainda reduzido, não pode ser esquecido o papel de programas preventivos desenvolvidos dentro dos presídios.

De forma geral, os presidiários têm ciência dos mecanismos de transmissão, sobretudo da relevância da via sexual. Contudo, a implementação de medidas preventivas ainda é mínima, apontando para a necessidade de desenvolvimento e manutenção de atividades agressivas com vistas à educação continuada e o aconselhamento. Este último, sem dúvida, reúne um enorme potencial de produzir impactos positivos na luta contra a epidemia de AIDS, uma vez que estabelece uma relação de confiança orientada para a transmissão de conteúdos informativos, mais facilmente captados e incorporados pelos presidiários. A possibilidade de realizá-lo também em grupos abre a possibilidade de troca de experiências e informações, enriquecendo substancialmente o processo.

Finalmente, há clara necessidade de estudos epidemiológicos contínuos que forneçam informações atualizadas sobre o estado de saúde dos presidiários. A grande marginalização desse segmento populacional se reflete na pouca priorização a ele concedida por parte de pesquisadores e de serviços de saúde. Em decorrência, a ignorância acerca das condições de saúde no interior dos presídios constitui um sério obstáculo à definição e implementação de intervenções sanitárias de impacto.

Mesmo que limitado a um único presídio, espera-se que os resultados desse trabalho possam contribuir para lançar alguma luz sobre as condições atuais da AIDS no sistema carcerário brasileiro, estimulando a realização de outras investigações e servindo para orientar a adoção de medidas preventivas. 


\title{
6 CONCLUSÕES
}

\author{
O presente estudo demonstrou que a infecção pelo HIV entre os presidiários \\ da Penitenciária de Ribeirão Preto está associada às seguintes covariáveis: \\ - Comportamento homossexual; \\ - Incircuncisão; \\ - Uso prévio de drogas injetáveis; \\ - Compartilhamento de agulhas e seringas; \\ - Tempo máximo de 5 anos de condenação total.
}




\section{REFERÊNCIAS BIBLIOGRÁFICAS}

1. World Health Organization Department of HIVIAIDS. Global prevalence and incidence of selected curable sexually transmitted infections 2001;Nov:1-50.

2. Joint United Nations Programme on HIVIAIDS (UNAIDS) and World Health Organization (WHO). AIDS Epidemic update 2003;december. Disponível em www.unaids.org/Unaids/EN/Resources/Publications/ Acessado em 02/12/2003.

3. Dean-Gaitor, Hazel D, Fleming PL. Epidemiology of AIDS in incarcerated persons in the United States, 1994-1996. AIDS 1999;13(17):2429-35.

4. Singh S, Prasad R, Mohanty A. High prevalence of sexually transmitted and blood-borne infections amongst the inmates of a district jail in Northern India. Int J STD AIDS 1999;10:475-8.

5. Burattini M, Massad E, Rozman M, Azevedo R, Carvalho H. Correlation between HIV and HCV in Brazilian prisoners: evidence for parenteral transmission inside prison. Rev Saúde Pública 2000;34(5):431-6.

6. Vaz R, Gloyd S, Folgosa E, Kreissn J. Syphilis and HIV infection among prisoners in Maputo, Mozambique. Int J STD AIDS 1995;6:42-6.

7. Butler $\mathrm{T}$, Robertson $\mathrm{P}$, Kaldor J, Donovan B. Syphilis in New South Wales (Australia) prisons. Int J STD AIDS 2001;12:376-9. 
8. Catalan-Soares B, Almeida R, Proietti A. Prevalence of HIV-1/2, HTLV-I/II, hepatitis B virus (HBV), hepatitis C virus ( $\mathrm{HCV})$, Treponema pallidum and Trypanosoma cruzi among prison inmates at Manhuaçu, Minas Gerais State, Brazil. Rev Soc Bras Med Trop 2000;33(1):27-30.

9. Andrade A, Martelli C, Sousa L, Sousa M, Zicker F. Soroprevalência e fatores de risco em população carcerária de Goiás. Rev Inst Med Trop São Paulo 1989;31(3):177-82.

10. Poulin C, Alary M, Ringuet J, Frappier J, Roy E, Lefebvre J. Prevalence of Chlamydial infection and frequency of risk behaviors for STDs and HIV infection among adolescents in public juvenile facilities in the Province of Quebec. Can J Public Health 1997;88(4):266-70.

11. Rozman M, Massad E, Silveira A, Azevedo-Neta R, Yamamoto Y, Strazza L, Meneghin P, Ferreira M, Carvalho H, Buchalla C, Schechtman M, Burattini M. HIVIAIDS in a Brazilian prison. Int J STD AIDS 1998;9(3):183-4.

12. Kassira E, Bauserman R, Tomoyasu N, Caldeira E, Swetz A, Solomon L. HIV and AIDS surveillance among inmates in Maryland prisons. J Urban Health $2001 ; 78(2): 256-63$.

13. Wolfe MI, Xu F, Patel P, O`Cain M, Schillinger J, St. Louis ME, Finelili L. An outbreak of syphilis in Alabama prisons: correctional health policy and communicable disease control. Am J Public Health 2001;91(8):1220-5.

14. Allright S, Bradley F, Long J, Barry J, Thornton L, Parry J V. Prevalence of antibodies to hepatitis B, hepatitis $\mathrm{C}$ and HIV and risk factors in Irish prisoners: results of a national cross sectional survey. BMJ 2000;321(8):7882. 
15. Rotily M, Vernay-vaisse C, Bourliére M, Galinier-Pujol A, Rousseau SO. HBV and HIV screening and hepatitis B immunization programme in the prison of Marseille, France. Int J STD AIDS 1997;8(12):753-9.

16. Zanetta DMT, Stazza L, Azevedo RS, Carvalho HB, Massad E, Menezes RX, Ferreira DP, Burattini MN. HIV infection and related risk behaviors in a disadvantaged youth institution of São Paulo, Brazil. Int J STD AIDS 1999;10:98-104.

17. Osti NM, Castro AFP, Ricci LC. Human Immunodeficiency Virus seroprevalence among inmates of the Penitentiary Complex of the Region of Campinas, State of São Paulo, Brazil. Mem Inst Oswaldo Cruz, Rio de Janeiro, 1999;94(4):479-83.

18. Broutet N, Sousa AQ, Basílio FP, Sá HL, Simon F, Dabis F. Prevalence of HIV-1, HIV-2 and HTLV antibody, in Fortaleza, Ceara, Brazil, 1993-1994. Int J STD AIDS 1996;7:365-9.

19. Mutter RC, Grimes RM, Labarthe D. Evidence of intraprison spread of HIV infection. Arch Int Med 1994;154:793-5.

20. Polonsky S, Kerr S, Harris B, Gaiter J, Fichtner R, Kennedy M. HIV Prevention in Prisons and Jails: Obstacles and Opportunities. Public Health Rep 1994;109(5):615-25.

21. Massad E. HIVIAIDS no sistema prisional brasileiro. In: A epidemia de AIDS no Brasil - Situações e Tendências. Ministério da Saúde, 1997;87-104. 
22. Menesia EO. Estudo epidemiológico sobre a Síndrome da Imunodeficiência Humana Adquirida (AIDS) no Município de Ribeirão Preto, SP, Brasil. Ribeirão Preto, 1999. Dissertação Mestrado - Faculdade de Medicina de Ribeirão Preto, Universidade de São Paulo.

23. Ruiz JD, Molitor F, Plagenhoef JA. Trends in hepatitis C and HIV infection among inmates entering prisons in California, 1994 versus 1999. AIDS 2002;16(16):2236-8.

24. Simooya OO, Sanjobo NE, Kaetano L, Sijumbila G, Munkonze FH, Tailoka F, Musonda R. "Behind wall": a study of HIV risk behaviors and seroprevalence in prisons in Zambia. AIDS 2001;15(13):1741-4.

25. Coordenação Nacional de DST e AIDS. Boletim Epidemiológico de AIDS. Ministério da Saúde, 2002;abril a dezembro.

26. Szwarcwald CL, Carvalho MF. Estimativa do número de indivíduos de $\mathbf{1 5}$ a 49 anos infectados pelo HIV. Coordenação Nacional de DST e AIDS. Ministério da Saúde, 2000.

27. Ministério da Justiça . Secretaria Nacional de Justiça. Departamento Penitenciário Nacional. Perfil dos estabelecimentos prisionais e da população carcerária. 2003 Jun. Disponível em: www.mi.gov.br/depen/sistema brasil.htm. Acessado em 16/08/2003.

28. Wormser GP, Krupp LB, Hanrahan JP, Gavis G, Spira TJ. CunninghamRundles, S. Acquired Immunodeficiency Syndrome in Male Prisoners. Ann Intern Med 1983;98:297-303. 
29. Schryver A, Meheus A. - Epidemiologia das DSTs-(situação atual). In: Naud, P. - Doenças Sexualmente Transmissíveis \& AIDS. Porto Alegre, Artes Médicas Sul; 1993. p. 5-24.

30. World Health Organization. WHO Features No 152, WHO, Geneva, 1990.

31. Centers for Diseases Control and Prevention. Kaposi's sarcoma and Pneumocystis pneumonia among homosexual men - New York City and California. Morbid Mortal Weekly Rep 1981;30(25):305-8.

32. Centers for Diseases Control and Prevention. Pneumocystis pneumonia - Los Angeles. Morbid Mortal Weekly Rep 1981;30(21):250-2.

33. Gottlieb MS, Schoroff R, Schanker HM, Weisman JD, Fan PT, Wolf RA, Saxon A. Pneumocystis carinii pneumonia and mucosal candidiasis in previously health homosexual men evidence of new acquired cellular immunodeficiency. N Engl J Med 1981;10;305(24):1425-31.

34. Mansur H, Michelis MA, Greene JB, Onorato I, Stouwe RA, Holzman R S, Wormser G, Brettman L, Lange M, Murray HW, Cunningham-Rundles S. An outbreak of community-acquired Pneumocystis carinii pneumonia: initial manifestation of cellular immune dysfunction. $\mathbf{N}$ Engl $\mathbf{J}$ Med $1981 ; 305(24): 1431-38$.

35. Siegal FP, Lopez C, Hammer GS, Brown AE, Kornfeld SJ, Gold J, Hassett J, Hirschman SZ, Cunningham-Rundles S, Armstrong D. severe acquired immunodeficiency in male homosexuals, manifested by chronic perianal ulcerative herpes simplex lesions. N Engl J Med 1981;305(24):1439-44. 
36. Barré-Sinoussi F, Chermann JC, Rey F, Nugeyre MT, Chamaret S, Gruest J, Dauguet C, Axler-Blin C, Brun-vezinet F, Rozenbaum W, Montagnier L. Isolation of a T-lymphotropic retrovirus from a patient at risk of acquired immunodeficiency syndrome (AIDS). Science 1983;220:868-70.

37. Del Rio C, Curran JW. - Epidemiology and Prevention of Acquired Immunodeficiency Syndrome and Human Immunodeficiency Virus Infection. In: Mandell, G. L.; Bennett, J. E.; Douglas, R. G. (Ed). Principles and Practice of Infectious Diseases $5^{\text {th }}$ ed., Florida, USA: Churchill Livingstone, Inc, 2000. p. 1340-68.

38. Curran JW, Morgan MW, Ardí AM, Jaffe HW, Danowe WN, Dowdle WR. The epidemiology of AIDS: current status and future prospects. Science 1985;229:1352-7.

39. Centers for Diseases Control and Prevention. Current trends update: heterosexual transmission of acquired immunodeficiency syndrome and human immunodeficiency virus infections - United States. Morbid Mortal Weekly Rep 1989;38:423-4, 429-34.

40. Centers for Diseases Control and Prevention. Provisional public health service inter-agency recommendations for screening donated blood and plasma for antibody to the virus causing acquired immunodeficiency syndrome. Morbid Mortal Weekly Rep 1985;34:1-5.

41. Schoenbaum EE, Hartel D, Selwyn PA. Risk factors for human immunodeficiency virus infection in intravenous drug users. $\mathbf{N}$ Engl J Med 1989;321:874-9. 
42. Centers for Diseases Control and Prevention. Current trends update: acquired immunodeficiency syndrome - United States, 1989. Morbid Mortal Weekly Rep 1990;39:81-6.

43. Cliff AD, Smallman-Raynor MR. The AIDS pandemic: global geographical patterns and local spatial process. The Geographical Journal 1992;158(2):182-98.

44. Karpas A. Origin and spread of AIDS. Nature 1990;348:578.

45. Shannon GW, Pyle GF. The origin and diffusion of AIDS: A view from medical geography. Annals of the Association of American Geographers $1989 ; 79(1): 1-24$.

46. Gallo RC, Montagnier L. Prospect for the future. Science 2002;298(5599):1730-1.

47. Piot $P$, Bartos $M$, Ghys PD, Walker N, Schwartländer B. The global impact of HIVIAIDS. Nature 2001;410:968-73.

48. Schwartländer B, Garnett G, Walker N, Anderson R. AIDS in a New Millennium. Science 2000;289(5476):64-7.

49. Pan American Health Organization. Aids Surveillance in the Americas. Biannual Report. 2002; jun 1-21.

50. Centers for Diseases Control and Prevention. HIVIAIDS surveillance report 2001. Atlanta, Georgia: U.S. Department of Health and Human Services, CDC, 2001;13(2). 
51. United Nations Population Fund. Preventing HIV Infection, Promoting Reproductive Health. 2003 oct. Disponível em: www.unfpa.org/hiv/index.htm Acessado em 08/10/2003.

52. Clinton WJ. Turning the Tide on the AIDS Pandemic. $\mathbf{N}$ Engl $\mathbf{J}$ Med 2003;348:1800-2.

53. National Intelligence Council. The next wave of HIVIAIDS: Nigeria, Ethiopia, Russia, India and China. Washington, D. C.: Central Intelligence Agency, September 2002. (NIC publication no. ICA 2002-04D.)

54. Stoever J, Walker N, Garnett GP, Salomon JA, Stanecki KA, Ghys PD, Grassly NC, Anderson RM, Schwartländer B. Can we reverse the HIVIAIDS pandemic with an expanded response? Lancet 2002;360:73-7.

55. Gayle HD, Hill GL. Global Impact of Human Immunodeficiency Virus and AIDS. Clin Microbiol Rev 2001;14(2):327-35.

56. Castilho EA, Chequer P. A epidemiologia do HIVIAIDS no Brasil. Brasília, Ministério da Saúde, 1995.

57. Amato Neto V, Uip DE, Boulos M, Duarte MIS, Mendes CMF, Taketomi E, Longo IM, Mattos Filho JLP, Moura NC, Rocha TRF, Mendes MF. Síndrome da imunodeficiência adquirida (AIDS): descrição do primeiro caso autóctone no Brasil e estudo imunológico. Rev Paul Med 1983;101:165-8.

58. Brito AM, Castilho EA, Szwarcwald CL. AIDS e infecção pelo HIV no Brasil: uma epidemia multifacetada. Rev Soc Bras Med Trop 2001;34(2):207-17. 
59. Szwarcwald CL, Bastos FI, Esteves MAP, Andrade CLT. A disseminação da epidemia de AIDS no Brasil, no período de 1987 a 1996: uma análise espacial. Cad de Saúde Pública, Rio de Janeiro 2000;16(suppl. 1):7-19.

60. Barcellos C, Bastos El. Redes sociais e difusão da AIDS no Brasil. Bol Oficina Sanit Panam 1996;121:11-24.

61. Winkelstein WW, Lyman D, Padian N, Grant R, Samuel M, Wiley JA, Anderson RE, Lang W, Riggs J, Levy JA. Sexual practices and risk of infection by the human immunodeficiency virus - The San Francisco men's health study. JAMA 1987;257:321-5.

62. Heyward W, Curran JW. The epidemiology of AIDS in the United States. Scientific American 1988;259(4):52-9.

63. Des Jarlais DC, Friedman SR, Novick DM, Sotheran JL, Thomas P, Yancovitz SR, Mildvan D, Weber J, Kreek MJ, Maslanski R. HIV-1 infection among intravenous drug users in Manhattan, New York City, from 1977 through 1987. JAMA 1989;261:1088-12.

64. Des Jarlais DC, Friedman SR, Stoneburner RL. HIV infection and intravenous drug use: Critical issues in transmission dynamics, infection outcome and prevention. Rev Infect Dis 1988;10:151-8.

65. Darrow WW, Echenberg DF, Jaffe HW, et al. Risk factors for human immunodeficiency virus (HIV) infections in homosexual men. Am J Public Health $1987 ; 77: 479-83$. 
66. Lewis DK, Watters JK, Case P. The prevalence of high-risk sexual behavior in male intravenous drug users with steady female partners. Am J Public Health 1990;80:465-6.

67. Bastos FI, Barcellos C. Geografia social da AIDS no Brasil. Rev Saúde Pública 1995;29(1):52-62.

68. Guimarães MDC. estudo temporal das doenças associadas à AIDS no Brasil, 1980-1999. Cad de Saúde Pública, Rio de Janeiro 2000;16(suppl. 1):21-36.

69. Fernandes MAS, Antonio DG, Bahamondes RG, Cupertino CV. Conhecimentos, atitudes e práticas de mulheres brasileiras atendidas pela rede básica de saúde com relação às doenças de transmissão sexual. Cad de Saúde Pública, Rio de Janeiro 2000;16(suppl. 1):103-12.

70. Brasil. Ministério da Saúde. Coordenação Nacional de DST e AIDS. Boletim Epidemiológico de AIDS., 48ª/2001 a 13ª 2002 Semanas Epidemiológicas, outubro de 2001 a março de 2002.

71. Guimarães CD. - Mulheres, Homens e AIDS: o visível e o invisível. In: Parker, R.; Bastos, C.; Galvão, J.; Pedrosa, J. S. - A AIDS no Brasil. Rio de Janeiro, Relume-Dumará, 1994. p. 217-30.

72. Brasil. Ministério da Saúde. Coordenação Nacional de DST e AIDS. Boletim Epidemiológico de AIDS, $23^{\mathrm{a}}$ a $36^{\mathrm{a}}$ Semanas Epidemiológicas, 2000;julho a setembro.

73. Fonseca MG, Bastos FI, Derriço M, Andrade CLT, Travassos C, Szwarcwald CL. AIDS e grau de escolaridade no Brasil: evolução temporal de 1986 a 1996. Cad Saúde Pública 2000;16(Suppl.1):77-87. 
74. Fonseca MGP, Szwarcwald CL, Bastos FI. Análise sociodemográfica da epidemia de Aids no Brasil, 1989-1997. Rev Saúde Pública 2002;36(6):678-85.

75. Brasil. Ministério da Saúde. Coordenação Nacional de DST e AIDS. Boletim Epidemiológico de AIDS, $35^{\text {a }}$ a $47^{\text {a }}$ Semanas Epidemiológicas, 1999 setembro a novembro.

76. Parker R, Camargo KR Jr. Pobreza e HIV: aspectos antropológicos e sociológicos. Cad Saúde Pública 2000;16(Suppl1):89-102.

77. Pape JW, Liautaud B, Thomas F, Mathurin JR, Amand MM, Boncy M, Pean V, Pamphile M, Laroche AC, Johnson WD. Characteristics of the acquired immunodeficiency syndrome (AIDS) in Haiti. N Engl J Med 1983;309:94550.

78. Calleja JMG, Walker N, Cuchi P, Lazzari S, Ghys PD, Zacarias F. Status of the HIVIAIDS epidemic and methods to monitor it in Latin America and Caribbean region. AIDS 2002;16(suppl. 3):S3-S12.

79. Rodríguez CM, Marques LF, Touzé G. HIV and injection drug use in Latin America. AIDS 2002;16(suppl. 3):S34-S41 AIDS 2002;16(suppl. 3):S3-S12.

80. Cáceres CCF. HIV among gay and other men who have sex with men in Latin America and the Caribbean: a hidden epidemic?. AIDS 2002;16(suppl. 3):S23-S33.

81. Quinn TC, Zacarias FRK, St John RK. AIDS in the Americas: An Emerging Public Health Crisis. N Engl J Med 1989;320:1005-7. 
82. Schwartländer B, Coutinho R, Loures L. The HIVIAIDS epidemic in the Latin America and Caribbean Region. AIDS 2002;16(suppl. 3):S1-S2.

83. Paiva V, Ayres JR, Buchalla CM, Hearst N. Building partnerships to respond to HIVIAIDS: non-governmental organizations and universities. AIDS 2002;16(suppl. 3):S76-S82.

84. Izazola-Licea JA, Figueroa CA, Arán D, Piola S, Perdomo R, Hernández P, Saavedra-Lopez JA, Valladares-Cardona R. Country response to HIVIAIDS National Health accounts on HIVIAIDS in Brazil, Guatemala, Honduras, Mexico and Uruguay. AIDS 2002;16(suppl. 3):S66-S75.

85. Pan American Health Organization (PAHO) and Joint United Nations Programme on HIVIAIDS (UNAIDS). HIV and AIDS in the Americas: an epidemic with many faces. 2001 1-57.

86. São Paulo. Secretaria de Estado da Saúde. Centro de Referência e Tratamento DST/AIDS. Centro de Vigilância Epidemiológica. Programa Estadual de DST/AIDS. Bol Epidemiol 2002 outubro.

87. Pontes LR. Comportamento epidemiológico da infecção pelo Vírus da Imunodeficiência Humana na Região de Ribeirão Preto 1984 a 1991. Ribeirão Preto, 1992. Dissertação Doutorado - Faculdade de Medicina de Ribeirão Preto, Universidade de São Paulo.

88. World Health Organization. Guidelines for the control of tuberculosis in prisons, Geneva, Switzerland: World Health Organization, 1998; document $\mathrm{n}^{\circ} \mathrm{WHO} / \mathrm{TB} / 98.250$. 
89. Coninx R, Maher D, Reyes H, Grzemska M. Tuberculosis in prisons in countries with high prevalence. BMJ 2000;320(7232):440-2.

90. Ausina V, Cayla JA. Tuberculosis, recent transmissions and prisons. Med Clin (Barc) 2000;115(7):256-7.

91. Hanrahan JP, Wormser GP, Maguire GP, Delorenzo LJ, Gavis G. Opportunistic infections in prisoners. N Engl J Med 1982;307:498.

92. Centers for Diseases Control and Prevention. Acquired Immuno Deficiency syndrome (AIDS) in prisons inmates - New York, New Jersey. Morbid Mortal Weekly Rep. 1983 31:700-1.

93. Harding TW. AIDS in prison. Lancet 1987;ii:1260-3.

94. Maruschak LM. Bureau of Justice Statistics Bulletin. HIV in Prisons, 2000. 2002 Document NCJ 196023. Disponível em www.ojp.usdoj.gov/bjs/pub/pdf/hivp00.pdf Acessado em 15/10/2003.

95. Acedo A, Campos A, Bauzá J, Ayala C, Jover M, Herrero L, Cañigral G, Tascón A. HIV infection, hepatitis and syphilis in spanish prisons. Lancet $1989 ; j u l$ 22:226.

96. Pont J, Stutz H, Kahl W, Salzner G. HIV epidemiology and risk behavior promoting HIV transmission in Austrian prisons. Eur $\mathbf{J}$ Epidemiol 1994;10:285-9.

97. Burgueño FG, Benenson AS, Amor JS. HIV-1 prevalence in select Tijuana sub-populations. Am J Public Health 1991;81:623-5. 
98. Mckee KJ, Power KG. HIVIAIDS in prisons. Scott Med J 1992;37:132-7.

99. Horsburgh $\mathrm{CR}$, Jarvis $\mathrm{JQ}$, McArthur $\mathrm{T}$, Ignacio $\mathrm{T}$, Stock $\mathrm{P}$. Seroconversion to Human Immunodeficiency Virus in Prison Inmates. Am J Public Health 1990;80:209-10.

100. Gore SM, Bird AG, Burns SM, Goldberg DJ, Ross AJ. Drug injection and HIV prevalence in inmates of Glenochil prison. BMJ 1995;310:293-6.

101. Stark K, Bienzle U, Vonk R, Guggenmoos-Holzmann I. History of syringe sharing in prison and risk of hepatitis B virus, hepatitis $C$ virus, and human immunodeficiency virus infection among injecting drug users in Berlin. Int $\mathbf{J}$ Epidemiol 1997;26:1359-66.

102. Dolan K, Hall W, Wodak A, Gaughwin M. Evidence of HIV transmission in an Australia prison. Med J Aust 1994;160:734.

103. Krebs CP, Simmons M. Intraprison HIV transmission: An assessment of whether it occurs, how it occurs, and who is at risk. AIDS Educ Prev 2002;14(suppl B):53-64.

104. Marins JR, Page-Shafer K, Barros MBA, Hudes ES, Chen S, Hearst N. Seroprevalence and risk factors for HIV infection among incarcerated men in Sorocaba, Brazil. AIDS Behav 2000;4:121-8.

105. Kelley PW, Redfield RR, Ward DL, Burke DS, Miller RN. Prevalence and incidence of HTLV-III infection in a prison. JAMA 1986;256:2198-9. 
106. Curtis SP, Edwards A. HIV in UK prisons: a review of seroprevalence, transmission and patterns of risk. Int J STD AIDS 1995;6:387-91.

107. Brewer T, Vlahov D, Taylor E, Hall H, Munoz A, Polk B. Transmission of HIV-1 within a statewide prison system. AIDS 1988;2:363-7.

108. Carvell ALM, Hart GJ. Risk behaviours for HIV infection among drug users in prison. BMJ 1990;300:1383-4.

109. Dolan KA, Wodak A. HIV transmission in a prison system in an Australian State. Med J Aust 1999;171:14-7.

110. Centers for Disease Control. AIDS in correctional facilities. Morbid Mortal Weekly Rep 1986;35:2412-9.

111. Veronesi R, Camargo Filho FC, Schechtmann M, Neitzer E, Souza LNX, Zampieri G, Franco BN, Santos O. Aids entre presidiários brasileiros: considerações sobre o possível papel dos vírus HTLV-1 e HBV como cofatores implicados na patogênese da Aids. Rev Bras Med 1993;50:488-95.

112. Abade EC, Loffredo LCM, Telarolli R Jr. Perfil epidemiológico da AIDS numa população carcerária de Ribeirão Preto - SP, 1996. Rev Odontol UNESP 1999;28:285-99.

113. Behrendt C, Kendig N, Dambita C, Horman J, Lawlor J, Valhov D. Voluntary testing for human immunodeficiency virus (HIV) in a prison population with a high prevalence of HIV. Am J Epidemiol 1994;139:918-26. 
114. Lourenço R. Epidemiologia da infecção pelo VIH-1 nas instituições carcerárias masculinas do Complexo Penitenciário do Carandiru - São Paulo, SP. São Paulo, 1992. Dissertação Mestrado - Escola Paulista de Medicina, Universidade Federal de São Paulo.

115. Massad E, Rozman M, Azevedo RS, Silveira ASB, Takey K, Yamamoto Y I, Strazza L, Ferreira MMC, Carvalho HB, Burattini MN. Seroprevalence of HIV, HCV and syphilis in Brazilian prisoners: Preponderance of parenteral transmission. Eur J Epidemiol 1999;15:439-45.

116. Christensen PB, Krarup HB, Niesters HGM, Norder H, Georgsen J. Prevalence and incidence of bloodborne viral infections among Danish prisoners. Eur J Epidemiol 2000;16:1043-9.

117. Pallás JR, Fariñas-Álvarez $C$, Prieto $D$, Delgado-Rodriguez M. Coinfections by HIV, hepatitis $B$ and $C$ in imprisoned injecting drug users. Eur $\mathbf{J}$ Epidemiol 1999;15:699-04.

118. Martín V, Caylà JA, Morìs ML, Alonso LE, Pérez R. Predictive factors of HIVinfection in injecting drug users upon incarceration. Eur J Epidemiol 1998;14:327-31.

119. Green J, Heuston J, Whiteley C, Strang J. Heterosexual activity of male prisoners in England and Wales. Int J STD AIDS 2003;14:248-52.

120. Martín V, Caylà JA, Morís ML, Alonso LE, Pérez R. Evolución de la prevalencia desinfección por virus de la inmunodeficiencia humana en población reclusa al ingreso en prisión durante el período 1991-1995. Rev Esp Salud Pública 1997;71:269-80. 
121. Thaisri H, Lerwitworapong J, Vongsheree S, Sawanpanyalert $P$, Chadbanchachai C, Rojanawiwat A, Kongpromsook W, Paungtubtim W, Sringam $P$, Jaisue R. HIV infection and risk factors among Bangkok prisoners, Thailand: a prospective cohorte study. BMC Infec Dis 2003;3:25.

122. Hammett TM, Harmon MP, Rhodes W. The burden of infectious disease among inmates of and releases from US correctional facilities, 1997. Am J Public Health 2002;92:1789-94.

123. Mertz KJ, Voigt RA, Hutchins K, Levine WC, and the jail STD prevalence monitoring group. Findings from STD screening of adolescents and adults entering corrections facilities: implications for STD control strategies. Sex Transm Dis 2002;29:834-39.

124. Burchell AN, Calzavara LM, Myers T, Schlossberg J, Millson M, Escobar M, Wallace E, Major C. Voluntary HIV testing among inmates: sociodemographic, behavioral risk, and attitudinal correlates. J Acquir Immune Defic Syndr 2003;32:534-41.

125. Beena V, Peterman TA. Cost-effectiveness of HIV counseling and testing in US prisons. J Urban Health 2001;78:304-12.

126. Braithwaite RL, Arriola KR. J. Male Prisoners and HIV prevention: a call for action ignored. Am J Public Health 2003;93:759-63.

127. Desai AA, Latta T, Spaulding A, Rich JD, Flanigan TP. The importance of routine HIV testing in the incarcerated population: the Rhode Island experience. AIDS Educ Prev 2002;14(suppl.B):45-52. 
128. Weinstein C, Greenspan J. Mandatory HIV testing in prisons. [Letters] Am J Public Health 2003;93:1617.

129. World Health Organization, Special Programme on AIDS. WHO consultation on prevention and control of AIDS in prisons. Lancet 1987;2:1263-64.

130. Conselho Regional de Medicina do Estado de São Paulo. AIDS e ética médica. São Paulo, 2001. 94 p.

131. Hall W, Solowij N. Adverse effects of cannabis. Lancet 1998;352:1611-16.

132. Solowij N, Stephens RS, Roffman RA, Babor T, Kadden R, Miller M, Christiansen K, McRee B, Vendetti J, for the Marijuana Treatment project research group. Cognitive functioning of long-term heavy cannabis users seeking treatment. JAMA 2002;287:1123-31.

133. Kandel DB. Does marijuana use of other drugs? JAMA 2003;289:482-3.

134. Lynskey MT, Heath AC, Bucholz, Slutske, WS, Madden PAF, Nelson EC, Statham DJ, Martin NG. Escalation of drug use in early-onset cannabis users vs co-twin controls. JAMA 2003;289:427-33.

135. Sanchez Z, van der M, Napo SA. Seqüência de drogas consumidas por usuários de crack e fatores interferentes. Rev Saúde Pública 2002;36:42030.

136. Fergusson DM, Swain-Campbell NR, Horwood LJ. Arrests and convictions for cannabis related offences in a New Zealand birth cohort. Drug Alcohol Depend 2003;70:53-63. 
137. Kallas EG, Varella D, Ceneviva AC, Castelo A. HIV seroprevalence and risk factors in a Brazilian prison. Braz J Infect Dis 1998;2:197-04.

138. Miranda AE, Zago AM. Prevalência de infecção pelo HIV e Sífilis em sistema correcional para adolescentes. J Bras Doenças Sex Transm 2001;13:35-9.

139. Carpenter CL, Longshore D, Annon K, Annon JJ, Anglin MD. Prevalence of HIV-1 among recent arrestees in Los Angeles county, California: serial cross-sectional study, 1991 to 1995. J Acquir Immune Defic Syndr 1999;21:172-77.

140. Maden A, Swinton M, Gunn J. A survey of pre-arrest drug use in sentenced prisoners. Br J Addict 1992;87:27-33.

141. Joint United Nations Programme on HIVIAIDS (UNAIDS) and World Health Organization (WHO). Eastern Europe and Central Asia. Fact Sheet 2002. 2002; dec:1-2.

142. Brasil. Ministério da Saúde. Coordenação Nacional de DST e AIDS. Boletim epidemiológico de AIDS 2001;janeiro a março.

143. Blasotti A, Blotta MHSL, Gomes MCO. Inquérito sorológico sobre a prevalência de anticorpos anti-HIV em detentos da cadeia pública de Sorocaba. Rev Paul Med 1987;105:117-8.

144. Peixinho ZF, Mendes NF, Longo IM, Mouro NC, Hernandez HJ, Lacouture CL, Dines I, Coscina AL, Gonzaga AL, Giraldes PRC, Porto AGM, Nakaie C, Paiva ACM. Seroepidemiological studies of HIV-1 infection in large Brazilian cities. Nat Immun Cell Growth Regul 1990;9:133-6. 
145. Varella D, Tuason L, Proffitt MR, Escaleira N, Alquezar A, Bukowsl RM. HIV infection among Brazilian transvestites in prison population. AIDS Patient Care 1996;10:299-302.

146. Jabur A, Baldy JLS, Quesada RMB. AIDS, hepatite B e sífilis: prevalência da infecção em 158 presidiários da cadeia pública de Londrina. Rev Soc Bras Med Tropical 1991;24(suppl.II):169.

147. Carvalho ML, Biondi EJ, Veiga LP. Estudo transversal sobre prevalência da infecção pelo HIV no sistema penitenciário do RJ - 1997. In: Congresso Brasileiro de Epidemiologia, 4. 1998, Rio de Janeiro. Resumos... Rio de Janeiro: Armazém das Letras Gráfica e Editora, 1998. p. 194.

148. Harrison PM, Karberg JC. Bureau of Justice Statistics Bulletin. Prison and jail inmates at Midyear 2002. 2003 NCJ 198877. Disponível em www.ojp.usdoj.gov/bjs/pub/pdf/pjim02.pdf Acessado em 20/11/2003.

149. Spaulding A, Stephenson B, Macalino G, Ruby W, Clarke JG, Flanigan T P. Human immunodeficiency virus in correctional facilities: a review. Clin Infect Dis $2002 ; 35: 305-12$.

150. Dixon PS, Flanigan TP, DeBuono BA, Laurie JJ, De Ciantis ML, Hoy J, Stein M, Scott HD, Carpenter CC. Infection with the human immunodeficiency virus in prisoners: meeting the health care challenge. Am $\mathbf{J}$ Med 1993;95(6):629-35.

151. Salive ME, Smith GS, Brewer TF. Death in prison: changing mortality patterns among male prisoners in Maryland, 1979-87. Am J Public Health 1990;80(12):1479-80. 
152. Vlahov D, Brewer F, Castro KG, Narkunas JP, Salive ME, Ullrich J, Muñoz. Prevalence of antibody to HIV-1 among entrants to US correctional facilities. JAMA 1991;265:1129-32.

153. Glass GE, Hausler WJ, Loeffelholz PL, Yesalis CE. Seroprevalence of HIV antibody among individuals entering the Lowa prison system. Am J Public Health 1988;78(4):447-9.

154. Wu HZ, Baillargeon J, Grady JJ, Black SA, Dunn K. HIV Seroprevalence among Newly Incarcerated Inmates in the Texas correctional system. Ann Epidemiol 2001;11(5):342-6.

155. Hsieh T. Responding to the needs of prisoners who are infected with HIV in Taiwan. In: International AIDS Conference, XIV, 2002, Barcelona. Anais eletrônico... Disponível em: http://www.aids2002.com/include/printabstract. Acessado em 31/08/2003.

156. Bellis MA, Weild AR, Beeching NJ, Mutton KJ, Syed Q. Prevalence of HIV and injecting drugs use in men entering Liverpool prison. BMJ 1997;315:30-31.

157. Dye S, Isaacs C. Intravenous drugs misuse among prison inmates: implications for spread of HIV. BMJ 1991;302:1506-08.

158. Ford PM, Pearson M, Sankar-Mistry P, Stevenson T, Bell D, Austin J. HIV, hepatitis $C$ and risk behaviour in a Canadian medium-security federal penitentiary. QJ Med 2000;93:113-19.

159. Gaughwin MD, Douglas RM, Liew C, Davies L, Mylvaganam A, Treffke H, Edwards J, Ali R. HIV prevalence and risk behaviours for HIV transmission in South Australian prisons. AIDS 1991;5:845-51. 
160. Kebede Y, Pickering J, McDonald JC, Wotton K, Zewde D. HIV infection in an Ethiopian Prison. Am J Public Health 1991;81:625-27.

161. Best J, Blitchtein-Winicki D, Leiva-Rosado R, Valverde A, Suarez-Ognio LAN, Manrique-Chicom H. Survey of risk behavior and HIV prevalence in Peruvian prisons. In: International AIDS Conference, XIV, 2002, Barcelona. Anais eletrônico... Disponível em: http://www.aids2002.com/include/printabstract. Acessado em 31/08/2003.

162. Long J, Allwright S, Barry J, Reynolds SR, Thornton L, Bradley F, Parry JV. Prevalence of antibodies to hepatitis $B$, hepatitis $C$, and HIV and risk factors in entrants to Irish prisons: a national cross sectional survey. BMJ 2001;323:1-6.

163. Martin V, Bayas JM, Laliga A, Pumarola T, Vidal J, De Anta MTJ, Salleras L. Seroepidemiology of HIV-1 infection in a Catalonian penitentiary. AIDS 1990;4:1023-26.

164. Rotily M, Galinier-Pujol A, Obadia Y, Moatti JP, Toubiana P, Vernay-Vaisse C, Gastaut JA. HIV testing, HIV infection and associated risk factors among inmates in southeastern French prisons. AIDS 1994;8:1341-44.

165. Kindelán J, Jurado R, Aparicio A, Cantero P, Guijo S. Prevalencia de anticuerpos frente al virus de la inmunodeficiencia humana en reclusos y funcionarios de instituciones penitenciarias. Rev Clin Esp 1987;181:539.

166. Osti NM. Estudo de soropositividade para anticorpos anti-HIV e virus que atuam como co-fatores na AIDS, em presidiários do complexo carcerário da região de Campinas-SP. 1996. Dissertação Mestrado Instituto de Biologia, Universidade Estadual de Campinas, Campinas. 
167. Pallás J, Fariñas-Álvarez C, Prieto D, Llorca J, Delgado-Rodriguez M. Risk factors for monoinfections and coinfections with HIV, hepatitis $B$ and hepatitis $C$ viruses in northern Spanish prisoners. Epidemiol Infect 1999;123:95-102.

168. Piot P, Quinn TC, Taelman H, Feinsod FM, Minlangu KB, Wobin O, Mbendi N, Mazebo $\mathrm{P}$, Ndangi $\mathrm{K}$, Stevens $\mathrm{W}$, et al. Acquired immunodeficiency syndrome in a heterosexual population in Zaire. Lancet 1984;2:65-9.

169. Lazzarin A, Saracco A, Musicco M, Nicolosi A. Man-to-woman sexual transmission of the human immunodeficiency virus: risk factors related to sexual behavior, man's infectiousness, and woman's susceptibility. Arch Intern Med 1991;151:2411-16.

170. Mastro TD, Satten GA, Nopkesorn T, Sangkharomya S, Longini IM Jr. Probability of female-to-male transmission of HIV-1 in Thailand. Lancet 1994;343:204-07.

171. deVincenzi I. A longitudinal study of human immunodeficiency virus transmission by heterosexual partners. N Engl J Med 1994;331:341-46.

172. Cohen MS. Sexually transmitted diseases enhance HIV transmission: no longer a hypothesis. Lancet 1998;351(suppl.3):S5-S7.

173. Quinn TC. Association of sexually transmitted diseases and infection with the human immunodeficiency virus: Biological cofactors and markers of behavioral interventions. Int J STD AIDS 1996;7(suppl. 2):S17-S24. 
174. Alexander-Rodriguez T, Vermund SH. Gonorrhea and syphilis incarcerated urban adolescents: prevalence and physical signs. Pediatrics 1987;80:56164.

175. Cameron DW, Simonsen JN, D'Costa LJ, et al. Female to male transmission of human immunodeficiency virus type 1: risk factors for seroconversion in men. Lancet 1989;2:403-07.

176. Stamm WE, Handsfield HH, Rompalo AM, et al. The association between genital ulcer disease and acquisition of HIV infection on homosexual men. JAMA 1988;260:1429-33.

177. Holmberg SD, Stewart JA, Gerber AR, et al. Prior herpes simplex virus type 2 infection as a risk factor for HIV infection. JAMA 1988;259:1048-50.

178. Rottingen JA, Cameron DW, Garnett GP. A systematic review of the epidemiologic interactions between classic sexually transmitted diseases and HIV: how much really is known? Sex Transm Dis 2001;28:579-97.

179. Power KG, Markova I, Rowlands A, McKee KJ, Anslow PJ, Kilfedder C. Sexual behaviour in Scottish prisons. BMJ 1991;302:1507-08.

180. Chen JL, Bovée MC, Kerndt PR. Sexually transmitted diseases surveillance among incarcerated men who have sex with men: an opportunity for HIV prevention. AIDS Educ Prev 2003;15(suppl.A):117-26.

181. Spaulding A, Lubelczyk RB, Flanigan T. Can unsafe sex behind bars be barred? Am J Public Health 2001;91:1176-7. 
182. May JP, Williams EL Jr. Acceptability of condom availability in a US Jail. AIDS Educ Prev 2002;14(suppl.B):85-91.

183. Tourinho DR, Dourado I. Safe sex in the prison system in Salvador, Brazil: it is possible? In: International AIDS Conference, XIV, 2002, Barcelona. Anais eletrônico... Disponível em: http://www.aids2002.com/include/printabstract. Acessado em 31/08/2003.

184. Fink A. Circumcision and heterosexual transmission of HIV infection to men. $\mathbf{N}$ Engl J Med 1987;316:1546-7.

185. Weiss HA, Quigley MA, Hayes RJ. Male circumcision and risk of HIV infection in sub-Saharan Africa: a systematic review and meta-analysis. AIDS 2000;14:2361-70.

186. Lavreys L, Rakwar JP, Thompson ML, Jackson DJ, et al. Effect of circumcision on incidence of human immunodeficiency virus type 1 and other sexually transmitted diseases: a prospective cohort study of trucking company employees in Kenya. J Infec Dis 1999;180:330-6.

187. Kebaabetswe P, Lockman S, Mogwe S, Mandevu R, Thior I, Essex M, Shapiro RL. Male circumcision: an acceptable strategy for HIV prevention in Botswana. Sex Transm Infect 2003;79:214-19.

188. Auvert B, Buvé A, Lagarde E, Kahindo M, Chege J, Rutenberg N, et al. Male circumcision and HIV infection in four cities in sub-Saharan Africa. AIDS 2001;15(suppl.4):S31-S40.

189. Wilson R. Circumcision and veneral disease. Can Med Assoc J 1947;56:54-6. 
190. Szabo R, Short RV. How does male circumcision protect against HIV infection? BMJ 2000;320:1592-94.

191. Eyer-Silva WA. A circuncisão masculine e a transmissão heterosexual do HIV. Rev Saúde Pública 2003;37:678-86.

192. Kelly R, Kiwanuka N, Wawer MJ, Serwadda D, Sewankambo NK, WabwireMangen F, Konde-Lule JK, Lutalo T, Makumbi F, Gray RH. Age of ale circumcision and risk of prevalent HIV infection in rural Uganda. AIDS 1999;13:399-05.

193. Pisani E, Dadun, Sucahya PK, Kamil O, Jazan S. Sexual behavior among injection drug users in 3 Indonesian cities carries a high potential for HIV spread to noninjectors. J Acquir Immune Defic Syndr 2003;34:403-06.

194. Kennedy DH, Gwyneth N, Elliott L, Ditton J. Drugs misuse and sharing of needles in Scottish prisons. BMJ 1991;302:1507.

195. Brewer TF, Derrickson J. AIDS in prison: a review of epidemiology and preventive policy. AIDS 1992;6:623-28.

196. Weild AR, Gill ON, Bennett D, Livingstone SJM, Parry JV, Curran L. Prevalence of HIV, hepatitis $B$, and hepatitis $C$ antibodies in prisoners in England and Wales: a national survey. Commun Dis Public Health 2000;3:121-6.

197. Rothon DA, Mathias RG, Schechter MT. Prevalence of HIV infection in provincial prisons in British Columbia. Can Med Assoc J 1994;151:781-87. 
198. Royce RA, Seña A, Cates W, Cohen MS. Sexual transmission of HIV. N Engl J Med 1997;336:1072-78.

199. Doll DC. Tattooing in prison and HIV infection. Lancet 1988;9:66-7.

200. Dean AG, Dean JA, Coulombir D, Brendel KA, Smith DC, Burton AH, et al. Epi Info, version 6: a word processing database and statistics programs for epidemiology on microcomputers. Atlanta, Georgia: Centers for Disease Control and Prevention;1994.

201. StataCorp. 1999. Stata Statistical Software: release 6.0. College Station, Texas: Stata Corporation;1999.

202. Achcar JA, Janeiro V, Mazucheli J. Regression model for correlated binary data with random effects assuming a mixture of normal distributions. Comp Stat 2003; 18:39-55. 
APÊNDICE 1 


\title{
HOSPITAL DAS CLÍNICAS DA FACULDADE DE MEDICINA DE RIBEIRÃO PRETO DA UNIVERSIDADE DE SÃO PAULO
}

\author{
TERMO DE CONSENTIMENTO PÓS-INFORMAÇÃO
}

NOME DA PESQUISA:

"PREVALÊNCIA E FATORES DE RISCO PARA A INFECÇÃO DO

HIV NA POPULAÇÃO CARCERÁRIA MASCULINA DA PENITENCIÁRIA DE RIBEIRÃO PRETO.

PESQUISADOR RESPONSÁVEL:

Dr. HARNOLDO COLARES COELHO CRM 80946

\section{INFORMAÇOES DADAS AOS PACIENTES:}

1. O Sr. está sendo convidado a participar de uma pesquisa para saber quem está contaminado com o vírus da AIDS, com o vírus da hepatite $\mathrm{B}$, com o vírus da hepatite $C$ e com a sífilis.

2. Estas doenças são muito encontradas nos presos das cadeias de todo o país.

3. A AIDS se pega em relação sexual sem camisinha ou tomando sangue contaminado quando a pessoa é internada em hospital e tomando pico na veia com a mesma agulha que foi usada por muitas pessoas. A hepatite $B$ se pega da mesma maneira da AIDS. A hepatite $C$ se pega em tomando pico na veia com a mesma agulha que foi usada por muitas pessoas e tomando sangue contaminado em hospital. A sífilis se pega em relação sexual sem camisinha.

4. O vírus da AIDS causa queda da resistência da pessoa e ela pode ficar doente com várias infecções. Os vírus da hepatite $B$ e da hepatite $C$ causam inflamação no fígado e pode deixar a pessoa doente toda amarelada ou não. A sífilis é uma doença que se pega na relação sexual e pode causar feridas no pinto, na boca e manchas em todo corpo.

5. As pessoas podem ter qualquer um desses bichinhos que causam essas doenças e não sentir nada e nem ter nenhuma alteração no corpo. Dessa maneira, quem estiver contaminado vai poder se tratar antes de ficar doente se fizer os exames adequados.

6. Para fazer esses exames o Sr. vai ter que tirar sangue do braço. O Sr. vai sentir uma pequena dor no local da picada como se fosse tomar uma injeção. Vai ser tirado um tanto de sangue que cabe mais ou menos numa colher de sopa. Nos tubinhos que tiver o seu sangue vai ter um número e a primeira letra do seu nome e do seu sobrenome. Ninguém fora da cadeia vai saber que o Sr. fez exames. Nós garantimos que o resultado será dado só para o Senhor.

7. Essa pesquisa pode beneficiar o Sr., porque se nós descobrirmos uma dessas infecções no seu sangue, nós encaminharemos para tratamento adequado. Além disso, os resultados da pesquisa poderão, no futuro, fazer com que as autoridades possam estabelecer maneiras de prevenir e tratar outras pessoas.

8. O Senhor participará da pesquisa se quiser, podendo desistir a qualquer momento, sem que isso o prejudique. 


\title{
TERMO DE CONSENTIMENTO
}

$\mathrm{Eu}$,

após

tomar

conhecimento sobre o projeto "Prevalência e fatores de risco para a infecção do HIV na população carcerária masculina da Penitenciária de Ribeirão Preto", entendi e concordo em participar da pesquisa, autorizando a coleta de uma amostra de meu sangue para estudo dessas doenças, cujos resultados poderei conhecer e aos quais terei acesso individual e sigiloso. Autorizo a utilização e divulgação dos resultados, embora exija sigilo absoluto quanto á minha identidade.

OBS: O estudo me oferece também a pesquisa de marcadores para Hepatites $\mathrm{B}$ e $\mathrm{C}$, também de modo sigiloso.

Ribeirão Preto de de

Assinatura

\author{
PESQUISADOR RESPONSÁVEL \\ Dr. Harnoldo Colares Coelho \\ Cremesp 80946 \\ Fone de contato 602-2695
}


APÊNDICE 2 


\title{
QUESTIONÁRIO
}

\author{
DATA $1-1$
}

1. NOME

2. NASCIMENTO

IDADE

3. ESTADO CIVIL i 1.casado 2. solteiro 3. amasiado 4. viúvo 5. divorciado/separado

4. FILHOS i

5. LOCAL DE NASCIMENTO i 1. Ribeirão 2. região de Ribeirão 3. outra região de SP 4. outro estado

6. LOCAL DE RESIDÊNCIA i 1. Ribeirão 2. região de Ribeirão 3. outra região de SP 4. outro estado

7. ESCOLARIDADE i 1.Nenhuma; 2. até 2 anos; 3.2 a 5 anos; 4.5 a 8 anos; 5 . colegial incompleto; 6. colegial completo; 7. superior incompleto; 8. superior completo

8. TEMPO TOTAL DA PENA

9.TEMPO JÁ CUMPRIDO

10. JÁ INTERNOU EM REFORMATÓRIO/FEBEM i 1. sim; 2. não; 3. não sabe

11. DSTs PRÉVIA DO TIPO ULCERATIVA $\square$ 1. não; 2. uma vez; 3. mais de uma vez

12. ONDE TRATOU $\square$ 1.médico; 2. não tratou 3. não se aplica 
13. DSTS PRÉVIA DO TIPO NÃO ULCERATIVA, $\square$ 1.não; 2. uma vez; 3. mais de uma vez

14. ONDE TRATOU $\square$ 1.médico; 2. não tratou; 3. não se aplica

15. CIRCUNCIDADO $\square$ 1. sim; 2. não

16. TATUAGEM $\square$ 1. sim; 2. não

17. PIERCING $\square$ 1. sim; 2. não; 3. não sabe

18. JÁ FEZ TESTE ANTI-HIV $\square$ 1. não; 2. uma vez; 3. mais de uma vez; 4. não sabe

19. RESULTADO $\square$ 1. positivo; 2. negativo; 3. não sabe; 4. não se aplica

20. TRANSFUSÃO SANGUINEA $\square$ 1. não 2. uma vez 3. mais de uma vez 4. não sabe

21. RELACIONAMENTO SEXUAL COM USUÁRIOS DE DROGAS

i 1. sim; 2. não; 3. não sabe

22. USO DE DROGAS ILÍCITAS NÃO INJETÁVEIS AGORA OU PASSADO 1. sim; 2. não 3. não sabe QUE TIPO

23. USO DE DROGAS ILÍCITAS INJETÁVEIS NO PASSADO $\square$ 1. freqüentemente; 2. às vezes; 3.raramente; 4. uma vez; 5 . nunca ; 6 não se aplica

24. QUANTO TEMPO DE USO $\square$ 1. mais de 5 anos; 2.3 a 5 anos; 3.1 a 3 anos;

4. menos de 1 ano; 5. não se aplica

25. COMPARTILHAMENTO NO PASSADO DE AGULHAS/SERINGAS

PARA USO DE DROGAS ILÍCITAS $\square$ 1. freqüentemente; 2 . às vezes; 3.raramente; 4. uma vez; 5. nunca; 6. não se aplica 
26. USO ATUAL DE DROGAS ILÍCITAS INJETÁVEIS

vezes; 3. raramente; 4. uma vez; 5. nunca ; 6. não se aplica

27. COMPARTILHAMENTO ATUAL DE AGULHAS/SERINGAS PARA USO DE DROGAS ILÍCITAS $\square$ 1. freqüentemente; 2. às vezes; 3.raramente; 4. uma vez; 5. nunca; 6. não se aplica

28. PREFERÊNCIA SEXUAL $\square$ 1. heterossexual; 2. homossexual; 3. bissexual; 4. desconhecido

29. QUANTOS PARCEIROS TEVE UM ANO ANTES DA PRISÃO

30. VISITA ÍNTIMA $\square$ 1. sim; 2. não

31. USO DE PRESERVATIVO NA VISITA ÍNTIMA 1. sempre; 2. às vezes; 3. nunca; 4. não se aplica

32. SEXO C/ COLEGAS NA PRISÃO $\square$ 1. freqüentemente; 2. às vezes; 3. raramente; 4. uma vez; 5. nunca ; 6 . não sabe

33. FORMA $\square$ 1. ativo 2. passivo 3. ativo/passivo 4. só oral 5 . só masturbação; 6 . não se aplica

34. USO DE PRESERVATIVO QUANDO FAZ SEXO COM COLEGAS

1. sempre; 2. às vezes; 3. nunca; 4. não se aplica

35. JÁ TEVE ICTÉRICIA $\square$ 1. sim; 2. não; 3. não sabe

36. JÁ TEVE HEPATITE $\square$ 1. sim; 2. não; 3. não sabe

37. USO DE TABACO $\square$ 1. sim; 2. não; 3. não sabe 


\section{RESULTADO SOROLOGIA DO HIV}

ELISA $\square$ 1. reagente; 2. não reagente; 3 . indeterminado

IMUNOFLUORESCÊNCIA INDIRETA $\square$ 1. reagente; 2. não reagente;

3.indeterminado; 4. não realizado

WESTERN BLOT $\square$ 1. reagente; 2. não reagente; 3. indeterminado;

4. não realizado 
COELHO, Harnoldo Colares. Prevalência e Fatores de Risco...... 2004. 115 p. Dissertação de Mestrado. Faculdade de Medicina de Ribeirão Preto, Universidade de São Paulo.

\section{ERRATA}

$\begin{array}{lccc}\text { Página } & \text { Linha } & \text { Onde se lê } & \text { Leia-se } \\ \text { RESUMO } & 25 & \text { Incircuncisão } & \text { Presença de circuncisão } \\ \text { SUMMARY } & 25 & \text { Lack of circumcision } & \text { Circumcision } \\ 77 & 05 & \text { Incircuncisão } & \text { Presença de circuncisão }\end{array}$

